\title{
Bangladesh: Fifth Review Under the Three-Year Arrangement Under the Poverty Reduction and Growth Facility and Request for Waiver of Performance Criteria, Extension of the Arrangement, and Rephasing-Staff Report; Staff Statement; Press Release; and Statement by the Executive Director for Bangladesh on the Executive Board Discussion
}

In the context of the fifth review under the three-year arrangement under the Poverty Reduction and Growth Facility and request for waiver of performance criteria, extension of the arrangement, and rephasing, the following documents have been released and are included in this package:

- $\quad$ the staff report for the Fifth Review Under the Three-Year Arrangement Under the Poverty Reduction and Growth Facility and Request for Waiver of Performance Criteria, Extension of the Arrangement, and Rephasing prepared by a staff team of the IMF, following discussions that ended on September 14, 2006, with the officials of Bangladesh on economic developments and policies. Based on information available at the time of these discussions, the staff report was completed on October 6, 2006. The views expressed in the staff report are those of the staff team and do not necessarily reflect the views of the Executive Board of the IMF;

- $\quad$ a staff statement of October 27, 2006 updating information on recent developments;

- $\quad$ a Press Release summarizing the views of the Executive Board as expressed during its October 27, 2006 discussion of the staff report that completed the review; and

- $\quad$ a statement by the Executive Director for Bangladesh.

The documents listed below have been or will be separately released.

Letter of Intent sent to the IMF by the authorities of Bangladesh*

Memorandum of Economic and Financial Policies by the authorities of Bangladesh*

Technical Memorandum of Understanding*

*Also included in Staff Report

The policy of publication of staff reports and other documents allows for the deletion of marketsensitive information.

To assist the IMF in evaluating the publication policy, reader comments are invited and may be sent by e-mail to publicationpolicy@imf.org.

Copies of this report are available to the public from

International Monetary Fund $\bullet$ Publication Services

$70019^{\text {th }}$ Street, N.W. • Washington, D.C. 20431

Telephone: (202) 623-7430 • Telefax: (202) 623-7201

E-mail: publications@imf.org • Internet: http://www.imf.org

Price: $\$ 18.00$ a copy

International Monetary Fund

Washington, D.C. 



\section{INTERNATIONAL MONETARY FUND}

\section{BANGLADESH}

Fifth Review Under the Three-Year Arrangement Under the Poverty Reduction and Growth Facility, and Request for Waiver of Performance Criteria, Extension of the Arrangement, and Rephasing

Prepared by the Asia and Pacific Department

Approved by Steven Dunaway and Anthony Boote

October 6, 2006

- This report is based on discussions held April 30-May 10 and September 6-14

in Dhaka. The teams comprised Mr. Rumbaugh (head), Ms. Abdelati, and Messrs. Berezin, Bhundia, and Lueth (all APD), Akitoby and Kinoshita (both FAD), Perone (PDR), and Ismail (MFD expert), and were assisted by Mr. Dunn (resident representative). World Bank Dhaka staff and Mr. Bannerji (OED) participated in the discussions.

- The mission met with senior government officials, including Minister for Finance and Planning M. Saifur Rahman, Finance Secretary Siddiqur Rahman Choudhury, and Bangladesh Bank Governor Salehuddin Ahmed.

- PRGF Status: A three-year arrangement for SDR 347 million (65 percent of quota) was approved on June 20, 2003, and augmented in July 2004 by SDR 53 million (10 percent of quota) in accordance with the Trade Integration Mechanism. In June 2005, the arrangement was extended to December 31, 2006. A total of SDR 283 million has been drawn following completion of the fourth review in February 2006.

- Recent Board Discussions: The most recent Article IV consultation was concluded in June 2005. At the conclusion of the fourth PRGF review in February 2006, Directors commended the authorities' efforts in maintaining macroeconomic stability and in improving social indicators in spite of a difficult political environment. They stressed the importance of improving revenue collections and encouraged the authorities to continue to advance reforms in tax administration, banking, and the energy sector, as well as to improve overall governance. 


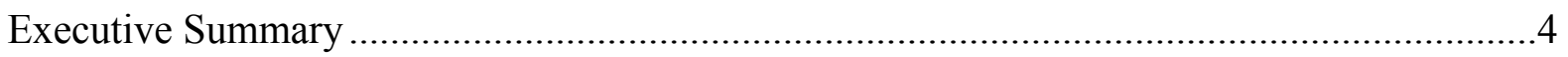

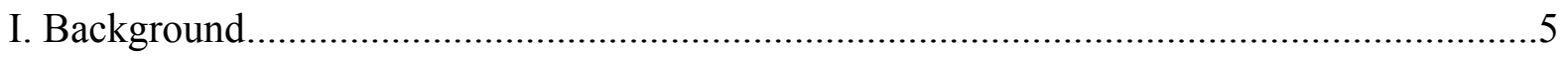

II. Recent Developments and Performance ................................................................6

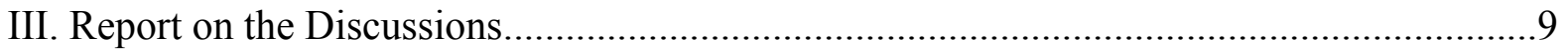

A. Macroeconomic Outlook......................................................................... 9

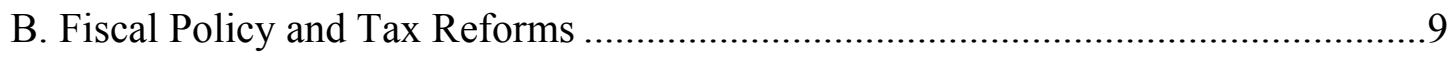

C. Monetary and Exchange Rate Policies.......................................................... 11

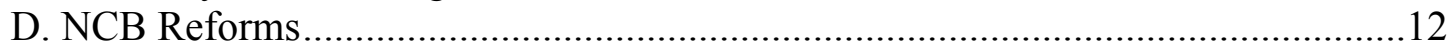

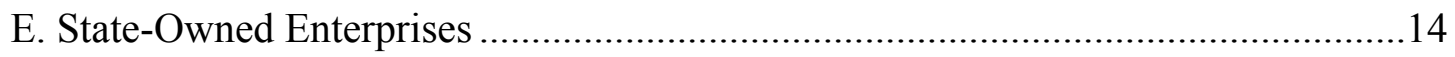

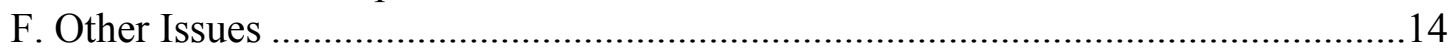

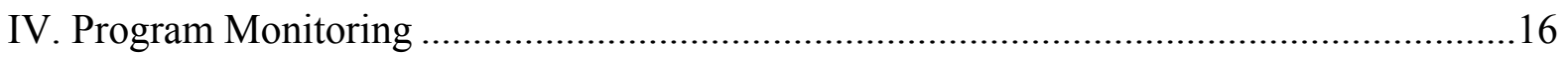

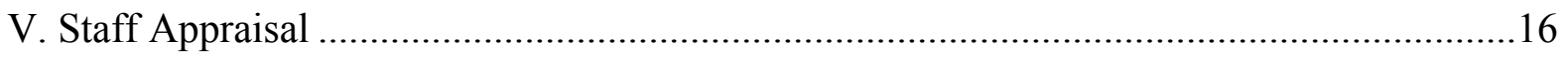

\section{Boxes}

1. Progress in Tax Administration Reforms .......................................................

2. Update on Bank Restructuring and Divestment ..............................................13

3. Fuel Prices in Bangladesh: Poverty Impact and Quasifiscal Losses .......................15

Figures

1. Monetary and Real Sector Indicators, FY99-06 .................................................. 19

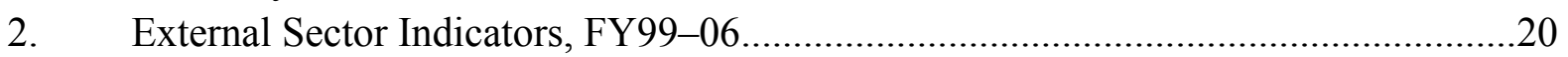

\section{Tables}

1. Millennium Development Goals, 1990-2005 .......................................................21

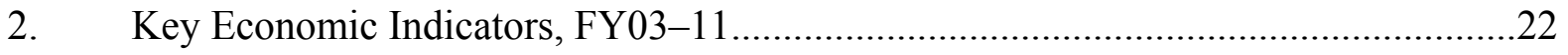

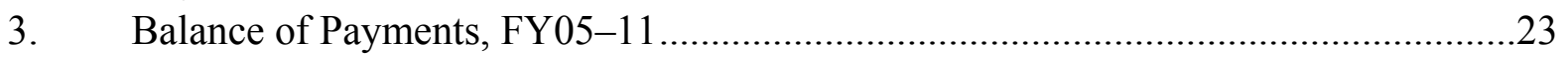

4. Central Bank Balance Sheet, June 2005-June 2007 ..............................................24

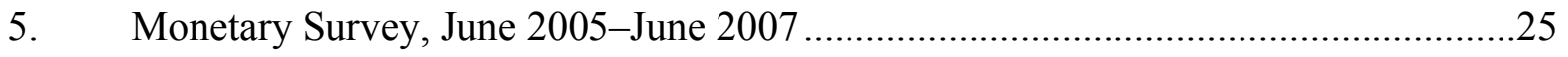

6. Central Government Operations, FY04-08 .............................................................26

7. Proposed Schedule of Disbursements Under the PRGF Arrangement and Augmentation of PRGF Access in Accordance with the Trade Integration Mechanism 
Annexes

I. Joint IMF-World Bank Debt Sustainability Analysis...........................................28

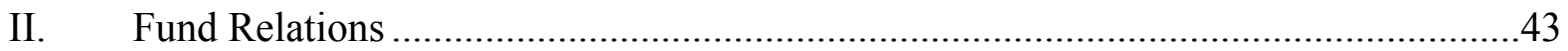

III. Relations with the World Bank Group ................................................................46

IV. Relations with the Asian Development Bank ....................................................50

Attachment

I. Letter of Intent and Memorandum of Economic and Financial Policies ....................52 


\section{EXECUTIVE SUMMARY}

Despite a contentious political environment, prudent macroeconomic policies have been largely maintained.

- $\quad$ Progress has been made toward reducing poverty and meeting the MDGs.

- Most of the program's objectives have been met. Growth has been sustained, inflation contained, and international reserves increased.

- Quantitative performance criteria for the fifth review were met with the exception of that for revenue collection. One structural performance criterion was observed, while the other was implemented with a delay.

Monetary policy has been gradually tightened and the exchange rate has stabilized in recent months, but further monetary tightening is needed. Interest rates have steadily increased, and the exchange rate has been allowed to move freely in response to market forces. However, strong domestic demand and rising import costs could put further upward pressure on prices.

The overall fiscal balance has been kept below budget and program targets, notwithstanding sizable revenue slippages. Revenue collections were targeted to increase by 0.5 percent of GDP in FY06 but remained unchanged at 101/2 percent of GDP. In spite of the shortfall, the overall deficit declined owing to slow development spending. However, net domestic financing slightly exceeded the June indicative target on account of unanticipated financing for state-owned enterprises. The FY07 budget introduced revenue measures to support a programmed increase in collections.

\section{Structural reform implementation continues at a moderate but steady pace.}

- Tax administration reforms have led to some improvements in domestic VAT and income tax collections but are yet to yield tangible gains in overall revenue owing to declines in customs revenue from tariff reductions.

- $\quad$ Divestment of Rupali Bank is nearing completion, and the regulatory and supervisory framework for the banking system has improved. However, corporatization of the other state banks, an important step for improving autonomy and accountability, has been delayed.

- Insufficient increases in domestic fuel prices in the face of a sharp rise in international prices have led to sizeable energy sector losses that are largely being financed by the state banks. The most recent energy price increases were implemented in June 2006. Further price adjustments are to be made in FY07, and remaining losses are to be covered through budget subsidies.

Given the relatively strong overall macroeconomic performance, but recognizing that some measures cannot be implemented at this point in the election cycle, staff supports the authorities' request for completion of the fifth PRGF review with a rephasing of remaining disbursements and extension of the arrangement to June 19, 2007. 


\section{BACKGROUND}

1. Bangladesh is reducing poverty and making headway toward meeting its MDGs. Sustained growth and innovative social programs have supported a steady reduction in extreme rural poverty, with the headcount ratio declining by 9 percentage points to 40 percent in the five years to 2005 , according to preliminary data. Progress on most human development indicators is impressive (Table 1), placing Bangladesh well on the way to meeting many of its MDGs. The

\begin{tabular}{|c|c|c|c|c|}
\hline \multicolumn{5}{|c|}{ Progress Toward Achieving the MDGs } \\
\hline & $1990-1$ & $2000-01$ & $2004-5$ & 2015 \\
\hline & \multicolumn{3}{|c|}{ Latest available } & Target \\
\hline Poverty headcount ratio (\%) & 59 & 49 & 40 & 29 \\
\hline Primary completion rate (\%) & 41 & 67 & NA & 100 \\
\hline Female primary enrollment rate $(\%)$ & 66 & 97 & 98 & 100 \\
\hline Youth literacy rate (\%) & 42 & 45 & 50 & 100 \\
\hline Under-5 mortality rate (per 1000 ) & 151 & 110 & 77 & 50 \\
\hline Infant mortality rate (per 1000) & 92 & 66 & 56 & 31 \\
\hline Maternal mortality rate (per 1000 ) & 5 & 4 & 3 & 1 \\
\hline
\end{tabular}
remaining social and economic challenges are daunting, however, as a large part of the population remains below the poverty line.

\section{Macroeconomic performance has been broadly in line with program objectives.}

- $\quad$ Economic growth has averaged 6 percent in the past four years.

- $\quad$ Reform of the foreign exchange regime has made possible sustained growth in exports and remittances, helped the economy to weather external shocks from rising oil prices and the end of the Multi-Fiber Agreement quotas, and facilitated the buildup of international reserves.

- $\quad$ Continued trade reform and more integration with global and regional economies are reflected in the increase of international trade from 28 percent of GDP in FY2000 to 38 percent of GDP in FY06.

- $\quad$ Monetary tightening has helped contain inflationary pressures from rising food and transport prices.

- $\quad$ Fiscal sustainability has been protected by limiting domestic financing of the budget deficit to 2 percent of GDP, and central government debt has been contained at 47 percent of GDP.

\section{However, political considerations are exerting an increasing influence on} economic policy decisions. The government faces pressures to ease monetary and fiscal policies in the run-up to the January 2007 elections, and the increasingly tense political environment has made it more difficult to proceed with fuel price adjustments and bank restructuring. At the same time, political demonstrations and frequent work stoppages continue to cloud the investment climate. Nonetheless, the authorities have pressed ahead with reforms and view continued support from international financial institutions as critical to sustained growth and poverty reduction. The current government will give way to an interim caretaker government appointed by the President in late October or early November. The caretaker government will have a mandate to implement policy decisions made by the 
previous government, and the PRGF-supported program would provide a macroeconomic framework during the course of this political transition.

\section{Recent Developments and Performance}

4. The growth momentum has been sustained, but inflation has increased. Industrial activity and export growth have remained robust and a rebound in agriculture following flood-related losses in 2004 helped boost overall growth from 6 percent in FY05 to an estimated $6 \frac{1}{2}$ percent in FY06 (Table 2). Inflation increased to $7 \frac{1}{2}$ percent in the last three months of FY06, mainly due to higher prices of petroleum products and imported food staples, and the pass-through impact from the depreciation of the taka by 10 percent in nominal effective terms during the previous year. Subsequently, inflation declined to $63 / 4$ percent in the 12 months to July 2006. (Figure 1).

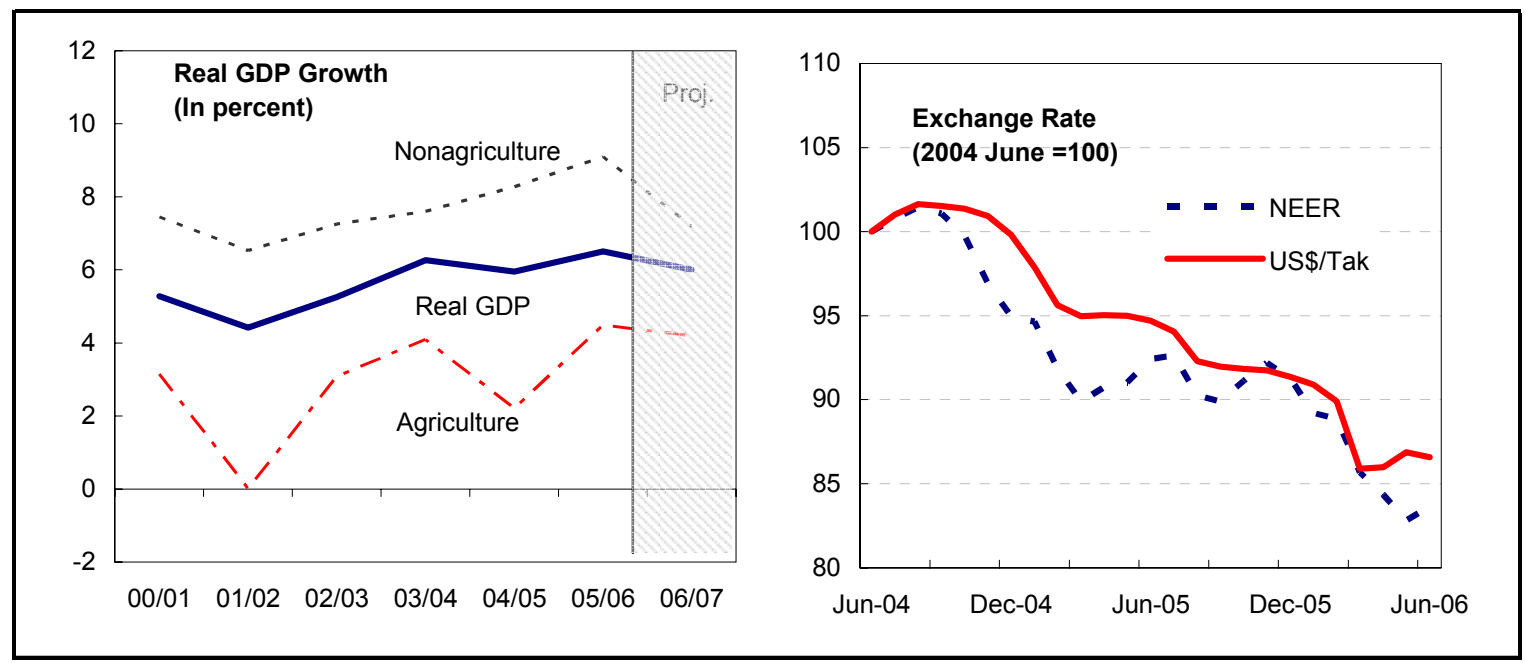

5. The external position has strengthened, the exchange rate has stabilized, and international reserves have increased in line with program targets. The current account registered a surplus of close to 1 percent of GDP in FY06, fueled by strong growth of exports and worker remittances ( 23 percent and 25 percent, respectively) and a slowdown in import growth (to about 12 percent) (Table 3). After missing the end-December 2005 benchmark for NIR by a small margin, the end-March 2006 performance criterion was exceeded by $\$ 112$ million. The exchange rate has stabilized since February at around Tk 70 per U.S. dollar, without further central bank foreign currency sales in the market, and the end-June NIR indicative target was also exceeded by $\$ 100$ million.

6. Bangladesh Bank (BB) has been gradually tightening monetary policy in the face of continuing inflationary pressures. Yields on treasury securities have increased by 2-3 percentage points since early 2005, but the rate on 28-day treasury bills remains only slightly above the rate of inflation. Private credit growth remains strong at 18 percent (yearon-year) in July 2006 (Table 5). The end-March performance criterion on NDA of BB was 
observed despite the higher-than-programmed growth of reserve money, but the June 2006 benchmark for NDA of BB was missed because of higher direct financing of the government. BB's monetary policy statement issued in July 2006 reiterates its commitment to a tightening of monetary policy so long as inflationary pressures persist.

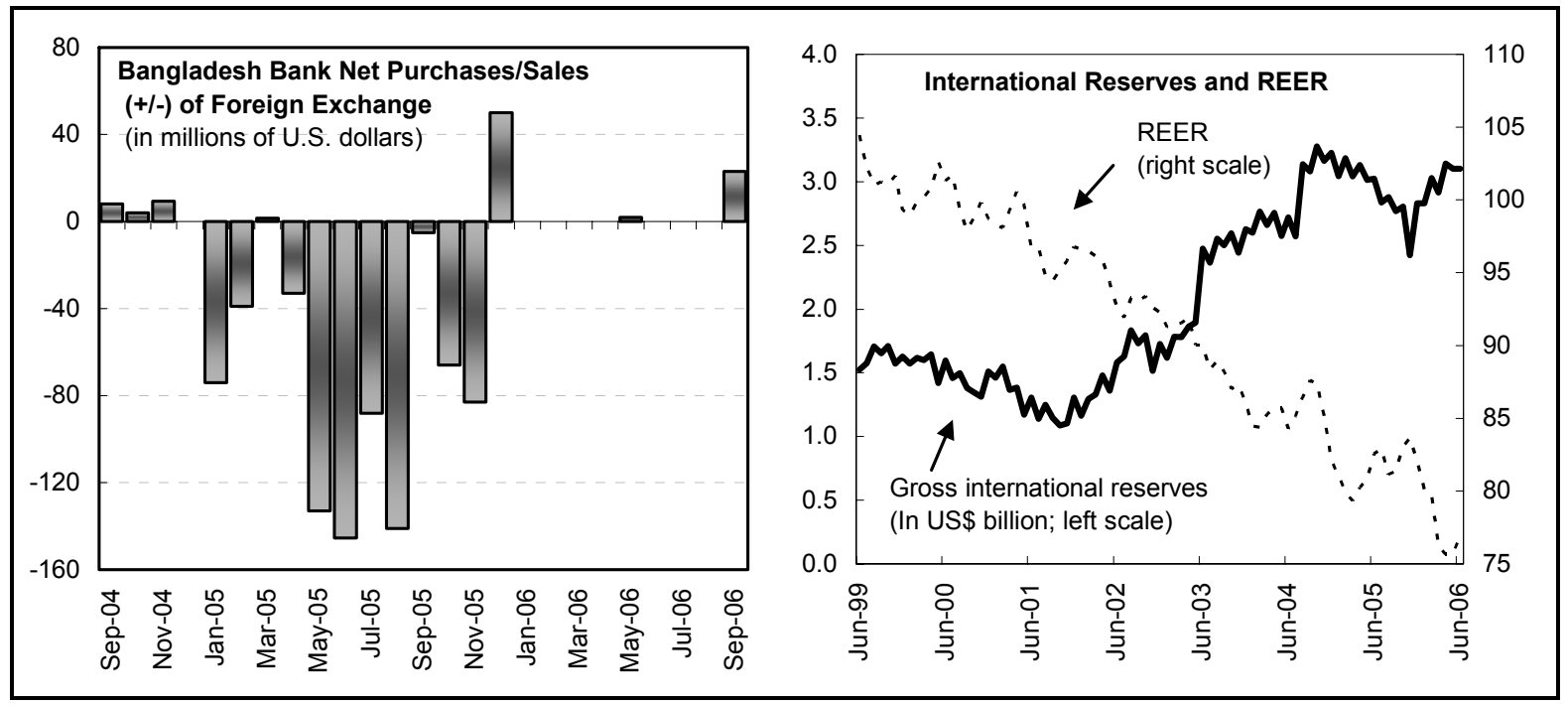

7. As in the past three years, the fiscal stance has been prudent, but revenue collections continue to fall short of the program target. Collections of the National Board of Revenue (NBR) were Tk 14 billion below the end-March performance criterion. For FY06, revenue collections at $101 / 2$ percent of GDP were lower than programmed by $1 / 2$ percent of GDP, owing to import duty reductions, tax arrears by the petroleum company, and lower-than-programmed non-oil imports (Table 6). Despite these shortfalls, the endMarch performance criterion on domestic financing of the central government was met by a wide margin (Tk 22 billion) on account of slow implementation of the Annual Development Program (ADP). The FY06 deficit of the central government declined to below $3 \frac{1}{2}$ percent of GDP. Nevertheless, the end-June indicative target on the government's domestic borrowing was breached by Tk 3 billion because of the need to cover quasi-fiscal losses in the energy sector.

\section{Structural reforms are slowly advancing.}

- $\quad$ Tax administration reform efforts appear to be gathering momentum (Box 1). For the first time since the start of the PRGF-supported program, the income tax and domestic VAT units achieved their revenue targets for FY06. 


\section{Box 1: Progress in Tax Administration Reforms}

Recognizing the need to boost revenue from current low levels, the authorities are implementing a threepronged strategy under the PRGF-supported program:

1. Setting up institutional structures: The Large Taxpayer Unit (LTU) for income tax and the Central Intelligence Cell (CIC) started operation in late 2003, followed by the LTU for VAT in late 2004.

2. Strengthening audit operations: Audit operations are expected to improve, with emphasis on joint audits between the VAT and income tax LTUs. Moreover, in late 2005, an audit unit was created and it is headed by an advisor that reports directly to the Chairman of the National Board of Revenue (NBR).

3. Modernizing the NBR: After a slow start, NBR modernization efforts appear to be gathering momentum. Supported by a new human resource policy and an information technology strategy, the threeyear modernization plan adopted in May 2005 includes the following components: (i) reorganization of the NBR along functional lines to permit clear lines of accountability; (ii) adoption of a true self-assessment system - to reduce discretion of tax officials; (iii) establishment of a risk-based auditing system supported by third-party information; and (iv) introduction of a unique taxpayer identification number (TIN).

After three years of implementation, tax administration reforms have advanced, and revenue collections have improved, albeit from a low base. Collections of domestic VAT and income tax have improved from 1.2 percent and 1.5 percent of GDP in FY03 to 1.5 percent and 1.7 percent in FY06, respectively. However, stronger efforts will be needed for the reforms to reach full fruition and this will require continued strong political commitment in support of the NBR. The most important next steps are to reorganize the NBR along functional lines, improve audit procedures, complete the introduction of uniform taxpayer ID numbers, and further improve collection and enforcement, notably at customs.

- $\quad$ The scope of tax exemptions has been reviewed. Although the study could not be completed by end-April (structural performance criterion), the authorities collected additional data and completed the analysis in August 2006.

- Bank restructuring is proceeding, albeit at a slower-than-expected pace. After a lengthy delay, the divestment of Rupali Bank is nearing completion with the announcement of a preferred bidder at end-August and the expected completion of the sales and purchase agreement in October. The other nationalized commercial banks (NCBs) have improved their performance somewhat in the last year, but the expected corporatization of the banks has been delayed.

- $\quad$ Domestic prices of petroleum products have been partially adjusted. Over the last three years, Bangladesh has passed about two-thirds of the world oil price increases through to domestic petroleum product prices, with the most recent price increases being made in June 2006. 


\section{REPORT ON THE DISCUSSIONS}

\section{Discussions focused on needed policy adjustments, including:}

- $\quad$ monetary and exchange rate policies to keep the financial program in line with program targets;

- $\quad$ revenue measures and further tax administration reforms to improve revenue performance;

- $\quad$ advancing the restructuring program for the NCBs; and

- $\quad$ further adjustment of domestic energy prices and containment of SOE losses.

\section{A. Macroeconomic Outlook}

10. The macroeconomic framework projects real growth of 6 percent in FY07.

Growth is expected to slow following the rebound in crop production in FY06 before picking up again in FY08. Inflation is expected to be contained at 7 percent in FY07, although the further pass-through of international oil price increases could temporarily boost prices before inflation begins to decline. Competitiveness gains and new investments in the garment sector should sustain export growth at around 15 percent in FY06, slowing to 10 percent by FY08. Import growth will remain strong over the period, resulting in a deterioration in the trade balance. The current account balance will also deteriorate, slipping back into deficit in FY08, but further increases in remittances should significantly moderate the decline. With net aid inflows projected to increase, it will be possible to increase international reserves in line with the medium-term target of three months of import coverage.

11. A number of risks to the outlook could lead to slower growth, higher inflation or a weaker external position. Domestically, continued political confrontation and associated disturbances could adversely affect economic activity. Rising power shortages and delayed decisions on power sector reforms also could constrain growth prospects if not addressed. Externally, further increases in oil prices and intensified competition in world textile markets (as discussed in Annex I) represent the major risks.

\section{B. Fiscal Policy and Tax Reforms}

\section{The medium-term fiscal strategy aims to boost revenue performance and} reorient expenditure to support growth and achievement of the MDGs while protecting fiscal sustainability. Consistent with the medium-term objectives, the authorities reiterated their commitment to raise revenue in FY07, with further improvements over the medium term, and to maintain the government deficit at below 4 percent of GDP. This would allow adequate support for human capital, physical infrastructure, and anti-poverty programs without threatening debt sustainability. 
Identified Additional Revenue Mobilization for FY2007 1/

\begin{tabular}{|c|c|c|c|}
\hline Item & Type & $\begin{array}{c}\text { Amount in } \\
\text { Tk billion }\end{array}$ & $\begin{array}{l}\text { Percent } \\
\text { of GDP }\end{array}$ \\
\hline 1. Minimum income tax and other items related to income tax & Income tax & 9.0 & 0.2 \\
\hline 2. Modification of accelerated depreciation schedule & Income tax & 2.5 & 0.1 \\
\hline 3. Higher profit transfers from government organizations & Nontax & 2.4 & 0.1 \\
\hline 4. Mobile telecom user and other fees & Nontax & 2.3 & 0.0 \\
\hline 5. Receipts for UN peacekeeping operations & Nontax & 1.8 & 0.0 \\
\hline 6. Changes in VAT and supplementary duties (SD) & VAT and SD & 1.3 & 0.0 \\
\hline \multirow[t]{2}{*}{ 7. Interest income from repayment on on lending } & Nontax & 0.8 & 0.0 \\
\hline & Sub-total & 20.0 & 0.4 \\
\hline \multicolumn{4}{|l|}{ Plus } \\
\hline Expected revenue gains from administrative reforms & Administrative & 10.0 & 0.2 \\
\hline \multicolumn{4}{|l|}{ Less } \\
\hline Reduction in customs tariffs and import supplementary duties & Customs & -10.0 & -0.2 \\
\hline Total revenue mobilization effort & Total & 20.0 & 0.4 \\
\hline
\end{tabular}

1/ The list includes measures contained in the budget and new measures since the budget.

\section{The FY07 program targets an overall deficit of 3.8 percent of GDP with} domestic financing capped at 2.4 percent of GDP. Staff estimates that the revenue measures included in the FY07 budget, and additional sources of revenue identified since the budget was adopted, are sufficient to generate an increase in overall revenue of 0.4 percent of GDP. In addition, given recent progress in strengthening tax administration reform (see Box 1), including the improved performance of the LTUs, this source is expected to contribute an additional 0.2 percent of GDP in revenue growth. However, these gains will be partly offset by revenue losses from further trade liberalization. As part of trade reforms agreed with the World Bank, supplementary duties were reduced and the government also decided to reduce some customs duties, together reducing average duties by 2.2 percentage points. The authorities stressed their commitment to strengthen the LTUs and further improve collection and enforcement (MEFP, $\mid 11-13$ ).

\section{Staff encouraged the authorities to take further steps to simplify the tax system} and expand the tax base. The recently completed study on tax exemptions and incentives identified potential revenue losses of about 2 percent of GDP, indicating that there is some scope to eliminate income tax holidays and domestic VAT exemptions. The authorities took the view that the tax holidays could be reviewed and reduced in FY08 when the current policy expires. However, given the difficulties in implementing sensitive reforms in the runup to the January 2007 elections, they would not be able to adopt additional tax policy measures at this time.

\section{On the expenditure side, the FY07 budget incorporates a further reordering of} priorities to favor poverty-reducing spending in line with the PRSP (MEFP, 『14). Poverty-reducing spending is projected to increase to $8 \frac{1}{2}$ percent of GDP, having been 
gradually increased from $5 \frac{1}{2}$ percent of GDP in 2002/03. Staff regretted that development spending did not increase in FY06 (relative to GDP) and expressed concern about the continued slow implementation of projects and the practice of setting unrealistic budget targets for the ADP. The authorities agreed on the need to enhance implementation capacity and to assess the effectiveness of poverty-reducing spending, noting that these will be reviewed in FY07 in the context of the recently initiated public expenditure review. Progress in improving the efficiency of poverty-reducing spending is also to be highlighted in an annual PRSP progress report, expected to be completed by mid-2007.

16. Staff welcomed the extension of the medium-term budget framework (MTBF) to more line ministries and urged further strengthening of public financial management (PFM). The MTBF has been rolled out to six more line ministries in the FY07 budget, bringing the total to 10 ministries. The government intends to expand the MTBF to another three ministries in FY08, which will bring MTBF coverage to more than 65 percent of total budget expenditure. The legal and regulatory framework of PFM has been strengthened with the adoption in June 2006 of a new law on public procurement (MEFP, $\{26$ ).

\section{Monetary and Exchange Rate Policies}

17. The authorities reiterated their commitment to take further corrective actions to tighten monetary conditions. To correct for the overshooting of the end-June 2006 indicative target for NDA of BB, staff argued that the monetary stance would need to be further tightened. Central Bank officials agreed and indicated that they would continue to tighten policy gradually in line with their July 17 monetary policy statement. Staff strongly endorsed BB's efforts to effectively communicate to the broader public the rationale for its policy actions through semi-annual monetary policy statements.

\section{The agreed monetary program for FY07 is consistent with inflation and}

international reserve objectives. Higher treasury yields would help reduce liquidity and growth in the monetary aggregates and private sector credit (which is expected to slow to a more sustainable rate of 14 percent). Gross official reserves are expected to rise to $\$ 3.8$ billion by June 2007 (around 2 $\frac{1}{2}$ months of imports).

19. Staff welcomed steps to improve the treasury securities market in line with Fund technical assistance recommendations. In the context of the FY07 budget, a Cash and Debt Management Committee has been established to monitor and project the government's financing requirements. In particular, the committee will aim to separate the government's short-term liquidity needs from its longer-term financing requirements. To provide the government with a sufficient short-term overdraft facility, an enhanced Ways and Means account has been created. Government's use of ad hoc treasury securities is being phased out and replaced with quantity-based auctions and BB's existing stock of government debt will be gradually transformed into marketable securities. 
20. The authorities remain committed to the flexible exchange rate regime and will confine interventions to countering disorderly conditions and building reserves as necessary (MEFP q20). The staff welcomed the improved functioning of the market and urged the authorities to continue its development.

\section{NCB Reforms}

21. The successful divestment of Rupali Bank is an important milestone for the bank restructuring program. A preferred bidder was announced at end-August (structural benchmark for end-June) following comprehensive technical evaluations and fit and proper tests of potential bidders by BB. The sales and purchase agreement is expected to be finalized in October. The authorities view the Rupali divestment as a model that can be applied to the divestment of the other state banks, and timing for future divestments is expected to be reviewed after the January elections. $\mathrm{BB}$ has also made considerable progress in improving the regulatory and supervisory framework for all banks (MEFP, $\mid 21)$.

\begin{tabular}{|c|c|c|c|c|}
\hline \multicolumn{5}{|c|}{ Banking Sector Indicators (In percent) } \\
\hline & 1998 & 2001 & 2004 & 2005 \\
\hline \multicolumn{5}{|c|}{ Capital to risk-weighted assets } \\
\hline NCB's & 5.2 & 4.2 & 4.1 & -0.4 \\
\hline PCB's & 9.2 & 9.9 & 10.3 & 9.2 \\
\hline FCB's & 17.1 & 16.8 & 24.2 & 25.4 \\
\hline Total $1 /$ & 6.9 & $\ldots$ & $\ldots$ & 7.3 \\
\hline \multicolumn{5}{|c|}{ Gross nonperforming loans to total loans $2 /$} \\
\hline NCB's & 40.4 & 37.0 & 25.3 & 21.4 \\
\hline PCB's & 32.7 & 17.0 & 8.5 & 5.6 \\
\hline FCB's & 4.1 & 3.3 & 1.5 & 1.3 \\
\hline \multicolumn{5}{|c|}{ Net nonperforming loans to total loans } \\
\hline NCB's & 26.8 & 25.2 & 17.6 & 13.2 \\
\hline PCB's & 16.3 & 4.5 & 2.7 & 1.8 \\
\hline FCB's & $\ldots$ & $\ldots$ & $\ldots$ & 0.7 \\
\hline \multicolumn{5}{|c|}{ Share of banking system assets } \\
\hline NCB's & 53.0 & $\ldots$ & 43.0 & 37.0 \\
\hline PCB's & 42.0 & $\ldots$ & 44.0 & 46.0 \\
\hline FCB's & 4.0 & & 7.0 & 7.0 \\
\hline \multicolumn{5}{|c|}{$\begin{array}{l}\text { Source: Bangladesh Bank based on bank reports. } \\
\text { 1/ Totals are weighted and include development finance institutions. } \\
\text { 2/ NPL not adjusted for actual provision or interest suspense. }\end{array}$} \\
\hline
\end{tabular}

22. The weak financial performance of the other NCBs remains an area of concern. Efforts to strengthen these banks (Box 2) are ongoing. Although low recovery of NPLs and capital shortfalls remain a key problem for the NCB's, their performance is now monitored against tightened prudential norms and lending limits, and their net open positions have been largely closed. Efforts are under way, in consultation with the World Bank, to give the managing directors and consulting teams in the NCBs greater authority and have their performance measured against agreed targets. Additionally, the authorities have taken steps toward corporatizing the banks to make them more autonomous and bring them under the regulatory purview of the central bank, but completion of the process has been delayed (corporatization of the banks is now proposed as a structural performance criterion for the sixth review). 


\section{Box 2: Update on Bank Restructuring and Divestment}

Since the late 1990s, the banking system in Bangladesh has become increasingly marketoriented: The share of assets in state-owned banks has declined from 53 percent in 1999 to 37 percent in 2005 and NCB lending to the private sector has declined. As private banks have grown in size and stature, the health of the banking system has improved: gross NPLs declined from 36 percent to 16 percent of total loans and advances during 1999-2005, while the net NPL ratio declined from 33 percent to less than 10 percent. This has led to a significant increase in banking system capital and profitability.

\section{BB has helped to facilitate these improvements by strengthening bank oversight:}

- on-site and off-site supervision has been stepped up;

- stricter accounting and auditing standards have been introduced, especially with regard to loan loss provisioning, bank exposure, loan write-offs, and large loan syndication;

- an early warning system for banks has been created;

- core risk management guidelines have been introduced in the areas of credit, foreign exchange, asset-liability management, internal control, and anti-money laundering;

- the minimum capital requirement on a risk-weighted basis has been raised from 8 to 9 percent;

- a fit and proper test for bank directors has been introduced and the existing test for bank CEOs has been tightened; and

- banks are now required to publish annual financial statements, which has helped to enhance transparency.

While available financial indicators suggest that the health of the private banks has improved, progress in reforming the NCBs has been slower and more uneven. Special audits conducted in 2003 confirmed that the NCBs were in a chronically poor position, with high levels of nonperforming loans and large capital shortfalls. To ringfence the NCBs, MOUs were signed with all four banks, which among other things, set a ceiling on the growth in each bank's lending portfolio, restricted single party exposure, and set targets on cash recoveries from defaulters. Performance under the MOUs has been satisfactory except for large amounts of state-mandated lending to BPC and low recovery from the largest defaulters. In addition, international management consultants were hired to help restructure the banks and place them on a path toward divestment. The next priority is to corporatize the banks to enhance their independence and place them under the supervisory purview of Bangladesh Bank, while proceeding over time with the divestment of the banks. After a series of delays, the divestment of Rupali Bank, the first of the NCBs slated for privatization, is nearing completion. 


\section{E. State-Owned Enterprises}

23. The mission stressed the urgency of addressing the quasi-fiscal losses of stateowned enterprises (SOEs), particularly the Bangladesh Petroleum Corporation (BPC). Domestic prices of petroleum products remain significantly below international prices and the implicit subsidies have been largely financed by the company borrowing from the NCBs to cover its losses. The automatic pricing formulas for petroleum products adopted in 2003 have been largely ignored, though a number of ad hoc price increases have been implemented over the past two years. Electricity tariffs also remain well below cost recovery levels and this contributes to investment and maintenance problems in the power sector, in addition to generating additional quasi-fiscal losses. Total SOE losses in FY06 were Tk 42 billion (1 percent of GDP), slightly more than in FY05. The biggest losses were made by BPC (Tk 32 billion), the Power Development Board (Tk 9 billion), and the national airline (Tk 8 billion). The World Bank and AsDB have program conditionality supporting power sector reforms and restructuring of energy SOEs (Annex III and IV).

\section{The authorities have completed a study of the fiscal costs arising from current} energy pricing policy (Box 3) that concluded that further fuel price and other energy tariff adjustments were inevitable. Staff urged the authorities to adopt social safety net measures to mitigate the impact of higher energy prices on the most vulnerable groups.

\section{Staff called for further price adjustments in FY07 and for reinstatement of the} automatic price adjustment mechanism. Although domestic fuel prices were adjusted on June 9, the increase was insufficient in view of global price developments. Prices of diesel and kerosene (the highest volume products) were raised by 10 percent. At the same time, the prices of gasoline and high octane were raised by 33 percent and 29 percent respectively, to slightly above the world price in order to provide a small cross-subsidy for some of the losses from diesel and kerosene. With this adjustment, prices of kerosene and diesel are at about 70 percent of the break-even level and losses of BPC are projected to remain at about the same level (about 3/4 percent of GDP) as in FY06 (at an average price of crude of \$63.5 in FY07). The authorities agreed to implement further price adjustments during the remainder of FY07 and to finance BPC losses in a more transparent manner through budget subsidy payments until the automatic pricing mechanism has been re-instated.

\section{F. Other Issues}

26. Improving governance remains a high priority for Bangladesh. Staff considers better governance as critical for improving the investment climate and prospects for growth. The authorities have taken steps to develop an anti-corruption strategy with the assistance of donors (MEFP, $\uparrow 26$ ) but specific actions to operationalize the strategy have been delayed, including the adoption of rules and regulations and staffing of the Anti-Corruption Commission. Public financial accountability is being strengthened, supported by World Bank 


\section{Box 3: Fuel Prices in Bangladesh: Poverty Impact and Quasifiscal Losses}

The prices of the main petroleum products in Bangladesh remain significantly below world prices. This has created incentives for smuggling of petroleum products to neighboring countries. Eliminating the subsidy implied by administered prices for diesel and kerosene would require prices to rise by $25-$ 35 percent. Although a pricing formula was introduced in 2003 for petroleum products, and in January 2004 for electricity, as part of the World Bank adjustment program, the formula has not been applied and prices are adjusted infrequently in an ad hoc manner.

\section{Administered prices benefit the rich more than the poor}

A recent poverty and social impact analysis conducted by the Fund's Fiscal Affairs Department reveals that energy subsidies are poorly targeted. Households in the poorest quintile (based on per capita consumption) receive only about 11 percent of the benefits of petroleum product subsidies. In contrast, the top quintile receives 35 percent of the benefit. Even most of the benefits from kerosene subsidies, which are often perceived to be pro-poor, accrue to wealthier households - the highest quintile of households (in consumption per capita terms) receive about 23 percent of the benefit as opposed to only 15 percent for the lowest quintile. For natural gas, the implicit subsidies from under-pricing are even less well targeted, as the bottom quintile receives only 9 percent of the benefits while the top quintile captures about 45 percent. A better way to target government assistance for poorer households would be to eliminate fuel subsidies and use the savings to increase spending on well-targeted social programs.

Share of Petroleum Subsidies Accruing to Different Households (Quintiles defined in terms of per capita consumption) 1/

\begin{tabular}{lrrrrr}
\hline & $\begin{array}{c}\text { Bottom } \\
\text { Quintile }\end{array}$ & $\begin{array}{c}\text { Second } \\
\text { Quintile }\end{array}$ & $\begin{array}{c}\text { Third } \\
\text { Quintile }\end{array}$ & $\begin{array}{c}\text { Fourth } \\
\text { Quintile }\end{array}$ & $\begin{array}{c}\text { Top } \\
\text { Quintile }\end{array}$ \\
\hline Direct effect & 0.14 & 0.17 & 0.19 & 0.21 & 0.30 \\
Indirect efect & 0.10 & 0.14 & 0.17 & 0.22 & 0.37 \\
$\quad$ Total effect & 0.11 & 0.15 & 0.17 & 0.22 & 0.35 \\
\hline
\end{tabular}

$1 /$ Using data from the 2000 Household Income Expenditure Survey.

\section{Delayed price adjustment has generated large SOE quasi-fiscal losses}

The study completed in April 2006 by the Ministry of Finance confirms the large quasi-fiscal costs in energy enterprises. It proposes phasing out energy subsidies and recommends expanding safety net programs for the poor. The report also recommends improving the operational efficiency of energy SOEs and reducing system leakages.

With respect to natural gas, the report uses a notional value of $\$ 1.38 / \mathrm{mcf}$ to estimate foregone revenue, which underestimates opportunity cost. Based on the current international value of natural gas of about $\$ 6 / \mathrm{mcf}$ (a more appropriate measure of opportunity cost in the view of staff), foregone revenue from the underpricing of natural gas would be equivalent to 2 percent of GDP.

Fuel Prices Relative to Breakeven Level and Implicit Subsidies

\begin{tabular}{lrrrrr}
\hline & Gasoline & Octane & Kerosene & Diesel & Jet Fuel \\
\hline Ratio of June 9 price to break-even level & 1.07 & 1.30 & 0.72 & 0.72 & 1.23 \\
Percent of total quantity consumed & 4.7 & 4.5 & 15.9 & 62.0 & 7.0 \\
Old subsidy as percent of GDP & 0.05 & 0.00 & 0.23 & 0.92 & 0.06 \\
New subsidy as percent of GDP 1/ & -0.02 & -0.06 & 0.19 & 0.75 & -0.07 \\
\hline
\end{tabular}

$1 /$ New subsidy if the average crude price in FY07 is US $\$ 63.5$ per barrel. 
and U.K. (DfID) assistance, and ongoing NCB and tax administration reforms are reducing opportunities for the misallocation of financial resources.

27. The authorities see merit in adopting measures to further facilitate trade. Ongoing customs automation and modernization are expected to reduce clearance delays and associated costs. Staff urged the authorities to further reduce administrative and regulatory constraints to trade and continue on the path of greater integration with regional and global economies.

28. The staff's debt sustainability analysis shows a moderate risk of debt distress. For external debt, the risk of debt distress is low as none of the indicative debt thresholds is breached in the baseline or alternate scenarios. Nevertheless, debt burden indicators are higher in the public sector DSA, which includes domestic debt, especially if significant contingent liabilities in SOEs are combined with lower GDP growth and/or a failure to improve revenue (Annex I). The authorities agreed with staff's analysis and conclusions and expressed their desire to strengthen their own debt monitoring and management capacity.

\section{Program Monitoring}

29. The program will continue to be monitored through quantitative and structural performance criteria and benchmarks. The authorities are requesting extension of the PRGF arrangement by an additional six months to June 2007 to allow time to complete the agreed reform measures. For the sixth review, which is expected to take place by May 31, 2007, quantitative performance criteria for end-December are proposed, as are indicative targets for end-March 2007, as well as structural conditionality (MEFP, Tables 2-3). Close coordination with the World Bank will continue in the areas of fiscal, NCB, and energy sector reforms. Given the inability of the government to address some key reform areas at this time, a portion of the sixth disbursement is proposed for rephasing to the seventh (and final) disbursement. This would make the final disbursement the largest under the PRGF and will require determined implementation of the remaining reform program by the next government.

\section{Staff Appraisal}

30. The Bangladesh authorities have significantly improved macroeconomic management under the program. The economy has weathered external shocks well and has continued to expand while inflation has generally been kept in check. However, in spite of making substantial progress in reducing poverty and toward meeting the MDGs, greater efforts will be needed to address infrastructure constraints, and to improve social services and the living conditions for the majority of the population, as emphasized in the PRSP.

\section{Political tensions continue to pose a potential risk to sound macroeconomic} management and implementation of structural reforms. Demonstrations, work stoppages, and a highly contentious political environment are likely to continue in the run-up to the 
January 2007 elections. Staff welcomes the authorities' commitment to maintain prudent macroeconomic policies and to forge ahead with structural reforms under the PRGFsupported program.

\section{Staff welcomes the improved functioning of the foreign exchange market.}

Adjustments in the exchange rate have helped absorb the shock of higher oil prices and the phase out of MFA quotas on garments while safeguarding the balance of payments position. Staff encourages the authorities to continue to refrain from interventions in the foreign exchange market other than to counter disorderly conditions and build international reserves in line with program targets.

33. The monetary program for FY07 is consistent with the authorities' inflation and international reserve objectives. Some further tightening of monetary policy will likely be needed in the face of strong domestic demand and the pass-through effect of domestic fuel price adjustments, and to correct for overshooting the June NDA and reserve money indicative targets. The staff encourages BB to use open market operations more actively. It also welcomes the decisions to introduce a market-based auction system with an announced monthly treasury bill calendar and to convert into marketable securities part of the stock of government debt held by the BB.

\section{Revenue mobilization has been the biggest disappointment in macroeconomic} policy under the PRGF-supported program. Better revenue mobilization would help to provide additional funding for infrastructure and poverty-related spending needs. Staff recognizes that improvements in tax administration are beginning to appear and this has helped facilitate a reorientation of taxation toward domestic sources and away from imports. However, this has not yet translated into significant revenue gains and the revenue shortfall in FY06 is regrettable. Much more remains to be done to improve tax administration, reduce tax exemptions and incentives, and further strengthen compliance and enforcement. The income and VAT measures introduced in the FY07 budget more than offset the expected revenue loss from further reducing trade taxes and help to underpin the targeted increase in revenue to 11 percent of GDP. A forthcoming FAD tax policy mission should help support the authorities' efforts to identify priorities for near-term tax policy reforms. Further progress in strengthening NBR capacity will also depend on continued technical assistance from the World Bank, DfID, and the Fund.

35. Greater efforts will be needed to improve the implementation capacity of the annual development program and the effectiveness of poverty-reducing spending. Staff urges the authorities to address these as priority issues in the forthcoming public expenditure review.

36. NCB reform efforts need to be stepped up. The divestment of Rupali Bank is a critical milestone and provides a positive signal for the overall NCB reform effort. Therefore, staff urges the government to finalize the bank's divestment as soon as possible. Staff supports the steps taken to strengthen monitoring of the other NCBs under MOUs agreed 
with $\mathrm{BB}$ and urges the authorities to corporatize the banks as soon as possible to improve their autonomy, as well as allow for more comprehensive supervisory oversight by the central bank. The managements and boards of the banks should be held accountable for the performance indicators designed in consultation with the World Bank.

\section{Staff is encouraged by the authorities' commitment to further oil price} adjustments and to increase transparency of the fiscal burden being created by the energy sector SOEs. While appreciating the difficulty of implementing further fuel price adjustments beyond those of June 2006, further price adjustments are unavoidable and energy pricing policy will remain an important component of discussions for the next review. The automatic pricing mechanism should be reinstated by FY08 to eliminate the need for fuel subsidies and provide more room for priority spending on social services and infrastructure. The authorities are also encouraged to take credible steps to address the problems of other loss-making SOEs.

38. Overall performance under the program has been satisfactory. In the attached letter of intent, the authorities have reiterated their commitment to economic reforms and have expressed their readiness to persevere despite the difficult political environment. Given the corrective actions, staff supports the request for waivers and the authorities' request to extend the program by another six months, with rephasing of the remaining disbursements. Completion of the sixth and final PRGF review will require determined and reinvigorated implementation of the remaining reform program by the next government. 
Figure 1. Bangladesh: Monetary and Real Sector Indicators, FY99-06
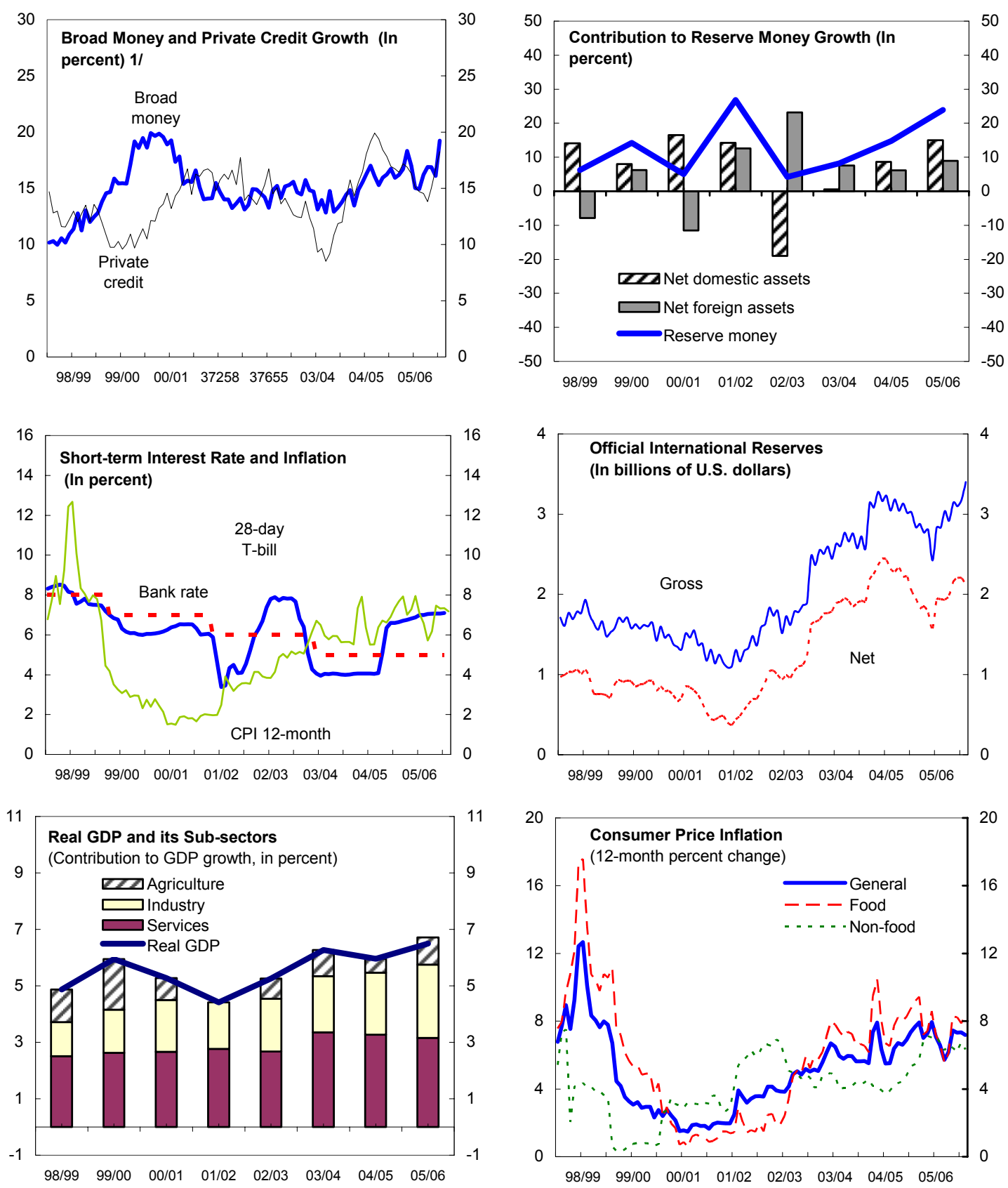

Sources: Data provided by the Bangladesh authorities; IMF, Information Notice System, International Financial Statistics; and IMF staff projections.

1/ Preliminary for June 06. 
Figure 2. Bangladesh: External Sector Indicators, FY99-06
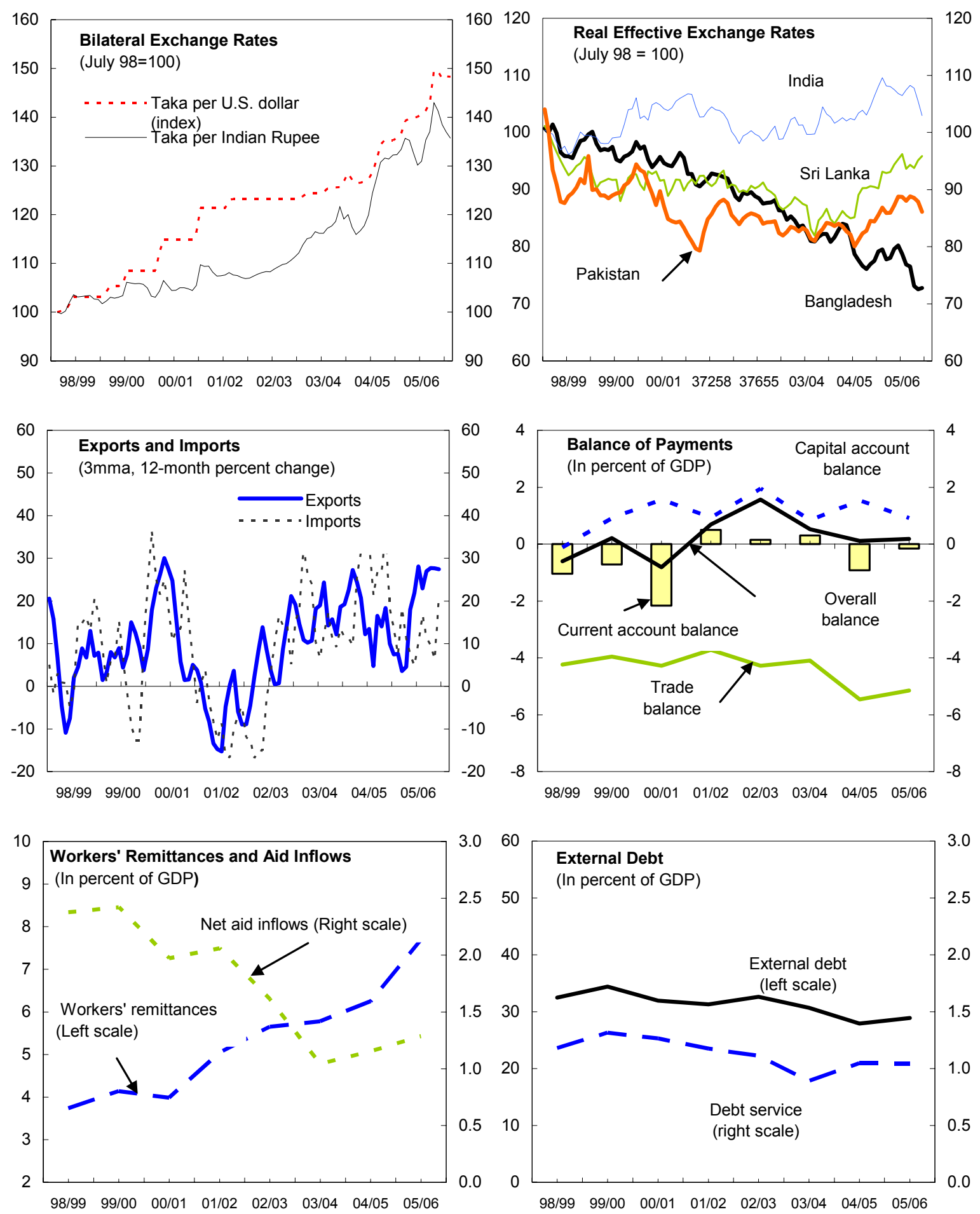

Sources: Data provided by the Bangladesh authorities; IMF, Information Notice System, International Financial Statistics; and IMF staff estimates and projections. 
Table 1. Bangladesh: Millennium Development Goals, 1990-2005 1/

\begin{tabular}{|c|c|c|c|c|c|}
\hline & 1990 & 1995 & 1998 & 2001 & 2004-05 \\
\hline Eradicate extreme poverty and hunger & \multicolumn{5}{|c|}{ ( 2015 target = halve $1990 \$ 1$ a day poverty and malnutrition rates) } \\
\hline Poverty headcount ratio & 58.8 & $\ldots$ & $\ldots$ & 49.8 & 40.8 \\
\hline Population below US $\$ 1$ a day (percent) 2/ & 35.9 & 28.6 & 26.7 & 36.0 & $\ldots$ \\
\hline Poverty gap at US $\$ 1$ a day (percent) $2 /$ & 8.8 & 6.0 & 5.1 & 8.1 & $\ldots$ \\
\hline Share of income or consumption held by poorest 20 percent (percent) & & & & 9.0 & $\ldots$ \\
\hline Prevalence of child malnutrition (percent of children under 5) & 65.8 & 57.0 & 62.0 & 52.0 & 48.0 \\
\hline Population below minimum level of dietary energy consumption (percent & 35.0 & 40.0 & 38.0 & 30.0 & $\ldots$ \\
\hline Achieve universal primary education & \multicolumn{5}{|c|}{$(2015$ target $=$ net enrollment to 100$)$} \\
\hline Net primary enrollment ratio (percent of relevant age group) & 71.2 & $\ldots$ & 90.1 & 86.6 & 93.8 \\
\hline Percentage of cohort reaching grade 5 (percent) & & & 54.7 & 65.5 & 65.3 \\
\hline Youth literacy rate (percent of ages $15-24$ ) & 42.0 & 44.5 & 46.5 & 48.4 & 49.7 \\
\hline Promote gender equality & \multicolumn{5}{|c|}{$(2015$ target $=$ education rate to 100$)$} \\
\hline Ratio of girls to boys in primary and secondary education (percent) & 77.1 & 76.1 & 96.3 & 104.3 & 105.5 \\
\hline Ratio of young literate females to males (percent of ages 15-24) & 65.5 & 67.3 & 68.7 & 70.0 & 71.1 \\
\hline Share of women employed in the nonagricultural sector (percent) & 17.6 & 20.5 & 22.2 & 22.9 & 24.2 \\
\hline Proportion of seats held by women in national parliament (percent) & 10.0 & $\ldots$ & 9.0 & 9.0 & 2.0 \\
\hline Reduce child mortality & \multicolumn{5}{|c|}{ ( 2015 target $=$ reduce 1990 under 5 mortality by two-thirds $)$} \\
\hline Under 5 mortality rate (per 1,000 ) & 149.0 & 120.0 & $\ldots$ & 92.0 & 77.0 \\
\hline Infant mortality rate (per 1,000 live births) & 100.0 & 83.0 & $\ldots$ & 66.0 & 56.0 \\
\hline Immunization, measles (percent of children under 12 months) & 65.0 & 79.0 & 72.0 & 76.0 & 77.0 \\
\hline Improve maternal health & \multicolumn{5}{|c|}{ ( 2015 target $=$ reduce 1990 maternal mortality by three-fourths) } \\
\hline Maternal mortality ratio (modeled estimate, per 100,000 live births) & $\ldots$ & $\ldots$ & $\ldots$ & 380.0 & $\ldots$ \\
\hline Births attended by skilled health staff (percent of total) & $\ldots$ & 9.5 & 8.0 & 12.1 & 13.0 \\
\hline Combat HIVIAIDS, malaria, and other diseases & \multicolumn{5}{|c|}{ ( 2015 target $=$ halt and begin to reverse AIDS, etc. $)$} \\
\hline Prevalence of HIV, female (percent of ages 15-24) & $\ldots$ & $\cdots$ & $\ldots$ & $\ldots$ & $\ldots$ \\
\hline Contraceptive prevalence rate (percent of women ages 15-49) & 31 & 44.9 & 54 & $\ldots$ & 59 \\
\hline Number of children orphaned by HIVIAIDS & $\ldots$ & $\ldots$ & $\ldots$ & $\ldots$ & $\ldots$ \\
\hline Incidence of tuberculosis (per 100,000 people) & 263.8 & 246.0 & 246.0 & 245.9 & 229.3 \\
\hline Tuberculosis cases detected under DOTS (percent) & $\ldots$ & 6.7 & 19.3 & 25.9 & 43.5 \\
\hline Ensure environmental sustainability & \multicolumn{5}{|c|}{ ( 2015 target $=$ various $3 /$ ) } \\
\hline Forest area (percent of total land area) & 7.0 & $\ldots$ & $\ldots$ & 7.0 & 7.0 \\
\hline Nationally protected areas (percent of total land area) & $\ldots$ & & 0.8 & 0.8 & 0.8 \\
\hline GDP per unit of energy use (PPP $\$$ per $\mathrm{kg}$ oil equivalent) & 10.1 & 10.3 & 10.4 & 10.9 & 10.5 \\
\hline CO2 emissions (metric tons per capita) & 0.1 & 0.2 & 0.2 & 0.3 & $\ldots$ \\
\hline Access to an improved water source (percent of population) & 71.0 & $\ldots$ & $\ldots$ & 75.0 & $\ldots$ \\
\hline Access to improved sanitation (percent of population) & 23.0 & 41.0 & $\ldots$ & 48.0 & 48.0 \\
\hline Develop a global partnership for development & \multicolumn{5}{|c|}{$(2015$ target $=$ various $4 /)$} \\
\hline Youth unemployment rate (percent of total labor force ages $15-24$ ) & 2.5 & 7.0 & 7.0 & 10.7 & $\ldots$ \\
\hline Fixed line and mobile telephones (per 1,000 people) & 2.1 & 2.5 & 3.9 & 8.3 & 37.0 \\
\hline Personal computers (per 1,000 people) & $\ldots$ & $\ldots$ & 1.0 & 1.9 & 11.9 \\
\hline \multicolumn{6}{|l|}{ General indicators } \\
\hline Population (millions) & 104.0 & 116.5 & 123.9 & 131.5 & 139.2 \\
\hline Gross national income (in billions of U.S. dollars) & 31.0 & 39.2 & 45.1 & 49.6 & 61.3 \\
\hline GNI per capita (in U.S. dollars) & 300.0 & 340.0 & 360.0 & 380.0 & 440.0 \\
\hline Adult literacy rate (percent of people ages 15 and over) & 34.2 & 36.5 & 38.3 & 40.0 & 41.1 \\
\hline Total fertility rate (births per woman) & 4.3 & 3.8 & 3.5 & 3.0 & 3.0 \\
\hline Life expectancy at birth (years) & 54.8 & 58.5 & 59.9 & 62.6 & 63.5 \\
\hline Aid per capita (current US\$) & 20.1 & 11.1 & 9.3 & 7.8 & 10.1 \\
\hline Investment (percent of GDP) & 17.1 & 19.1 & 21.6 & 23.1 & 24.0 \\
\hline
\end{tabular}

Sources: World Bank Development Indicators database; and IMF staff estimates.

$1 /$ In some cases the data are for earlier or later years than those stated.

2/ Based on the 1995-96 Household Expenditure Survey and the 2000 and 2005 Household Income and Expenditure Survey; data may not be comparable across time periods due to methodological differences in survey design.

$3 /$ Integrate the principles of sustainable development into country policies and programs and reverse the loss of environment resources. Halve the proportion of people without sustainable access to safe drinking water by 2015 .

4/ Develop further an open, rule-based, predictable, nondiscriminatory trading and financial system. Address the special needs of land locked countries and small island developing states. 
Table 2. Bangladesh: Key Economic Indicators, FY03-11 1/

\begin{tabular}{|c|c|c|c|c|c|c|c|c|c|c|}
\hline & \multirow[b]{2}{*}{$2002 / 03$} & \multirow{2}{*}{\multicolumn{2}{|c|}{$2003 / 042004 / 05$}} & \multicolumn{2}{|c|}{ Rev. Prog. Prelim. } & \multicolumn{5}{|c|}{ Projection } \\
\hline & & & & $2005 / 4$ & & $2006 / 07$ & $2007 / 08$ & $2008 / 09$ & $2009 / 10$ & $2010 / 11$ \\
\hline \multicolumn{11}{|l|}{ National income and prices (percent change) } \\
\hline Real GDP & 5.3 & 6.3 & 6.0 & 6.0 & 6.5 & 6.0 & 6.5 & 6.5 & 6.5 & 6.5 \\
\hline GDP deflator & 4.5 & 4.2 & 4.8 & 6.0 & 5.5 & 6.0 & 5.0 & 5.1 & 4.5 & 3.7 \\
\hline $\mathrm{CPI}$ inflation (annual average) $2 /$ & 4.4 & 5.8 & 6.5 & 7.5 & 7.0 & 7.0 & 5.2 & 5.1 & 4.5 & 3.7 \\
\hline \multicolumn{11}{|l|}{ Central government operations (percent of GDP) } \\
\hline Total revenue & 10.3 & 10.2 & 10.5 & 11.0 & 10.6 & 11.0 & 11.4 & 11.5 & 11.7 & 12.0 \\
\hline Tax & 8.3 & 8.2 & 8.5 & 9.0 & 8.5 & 8.8 & 9.4 & 9.5 & 9.6 & 9.8 \\
\hline Nontax & 2.0 & 1.9 & 2.0 & 2.0 & 2.1 & 2.1 & 2.0 & 2.1 & 2.1 & 2.2 \\
\hline Total expenditure & 13.7 & 13.1 & 13.9 & 15.1 & 13.9 & 14.8 & 14.9 & 15.1 & 15.3 & 15.5 \\
\hline Current expenditure & 8.1 & 7.8 & 8.4 & 8.7 & 8.4 & 9.1 & 8.3 & 8.3 & 8.3 & 8.2 \\
\hline Of which: Interest payments & 1.9 & 1.6 & 1.7 & 1.8 & 1.8 & 1.6 & 1.7 & 1.7 & 1.6 & 1.5 \\
\hline Of which: Subsidies & & 0.4 & 0.6 & 0.4 & 0.4 & 1.3 & 0.4 & 0.4 & 0.4 & 0.4 \\
\hline Annual Development Program & 5.4 & 5.0 & 5.0 & 5.4 & 4.7 & 4.9 & 5.7 & 5.6 & 5.8 & 6.2 \\
\hline Other expenditures $3 /$ & 0.2 & 0.3 & 0.5 & 1.0 & 0.8 & 0.8 & 0.9 & 1.2 & 1.2 & 1.1 \\
\hline Overall balance (excluding grants) & -3.4 & -2.9 & -3.4 & -4.0 & -3.3 & -3.8 & -3.5 & -3.6 & -3.6 & -3.6 \\
\hline Primary balance & -1.5 & -1.2 & -1.7 & -2.3 & -1.5 & -2.2 & -1.8 & -1.8 & -2.0 & -2.0 \\
\hline Financing (net) & 3.4 & 2.9 & 3.4 & 4.0 & 3.3 & 3.8 & 3.5 & 3.6 & 3.6 & 3.6 \\
\hline Domestic 4/ & 1.2 & 1.8 & 1.7 & 2.0 & 2.1 & 2.6 & 1.8 & 1.7 & 1.7 & 1.6 \\
\hline External & 2.1 & 1.1 & 1.6 & 2.0 & 1.2 & 1.2 & 1.7 & 1.9 & 1.9 & 2.0 \\
\hline Total central government debt (percent of GDP) & 51.1 & 48.7 & 47.6 & 48.5 & 46.9 & 45.7 & 44.1 & 42.5 & 41.4 & 40.7 \\
\hline \multicolumn{11}{|l|}{ Money and credit (end of year; percent change) } \\
\hline Net domestic assets & 12.2 & 13.4 & 17.1 & 15.0 & 19.6 & 14.4 & 14.7 & 14.4 & 14.3 & 13.5 \\
\hline Credit to private sector & 12.6 & 12.0 & 17.0 & 13.9 & 18.3 & 14.0 & 14.1 & 13.4 & 13.3 & 12.2 \\
\hline Broad money (M2) & 15.6 & 13.8 & 16.7 & 14.3 & 19.3 & 14.7 & 14.0 & 13.8 & 13.7 & 12.9 \\
\hline \multicolumn{11}{|l|}{ Balance of payments (in billions of U.S. dollars) $5 /$} \\
\hline Exports, f.o.b. & 6.5 & 7.5 & 8.6 & 9.6 & 10.4 & 12.0 & 13.2 & 14.5 & 15.9 & 17.5 \\
\hline (Annual percent change) & 9.5 & 15.8 & 14.0 & 11.7 & 23.1 & 15.2 & 10.0 & 9.8 & 9.8 & 9.9 \\
\hline Imports, f.o.b. & 8.7 & 9.8 & 11.9 & 13.7 & 13.3 & 15.4 & 17.6 & 19.4 & 21.1 & 22.9 \\
\hline (Annual percent change) & 13.1 & 13.0 & 20.6 & 15.0 & 12.1 & 16.0 & 14.0 & 10.5 & 8.7 & 8.4 \\
\hline Current account & 0.1 & 0.2 & -0.6 & -1.2 & 0.6 & 0.3 & -0.5 & -0.9 & -1.1 & -1.2 \\
\hline (Percent of GDP) & 0.1 & 0.3 & -0.9 & -1.9 & 0.9 & 0.4 & -0.6 & -1.2 & -1.3 & -1.3 \\
\hline Gross official reserves (in billions of U.S. dollars) & 2.5 & 2.7 & 2.9 & 3.3 & 3.4 & 3.8 & 4.6 & 5.3 & 6.2 & 7.1 \\
\hline In months of imports of goods and nonfactor services & 2.9 & 2.8 & 2.5 & 2.5 & 2.6 & 2.5 & 2.7 & 2.8 & 3.0 & 3.1 \\
\hline \multicolumn{11}{|l|}{ Memorandum item: } \\
\hline Nominal GDP (in billions of taka) & 3,006 & 3,330 & 3,707 & 4,142 & 4,166 & 4,682 & 5,235 & 5,863 & 6,527 & 7,214 \\
\hline
\end{tabular}

Sources: Data provided by the Bangladesh authorities; and IMF staff estimates and projections.

1/ Fiscal year begins July 1.

2/ CPI has recently been rebased using FY96 weights.

$3 /$ Consists of other capital, net lending, food account balances, check float and discrepancy.

4/ Includes estimated privatization receipts of 0.2 percent of GDP in FY07.

5 / Balance of payments is presented on the basis of BPM5. 
Table 3. Bangladesh: Balance of Payments, FY05-11 1/

(In millions of U.S. dollars, unless otherwise indicated

\begin{tabular}{|c|c|c|c|c|c|c|c|}
\hline & \multirow[b]{2}{*}{$04 / 05$} & \multirow{2}{*}{$\begin{array}{c}\text { Est. } \\
05 / 06\end{array}$} & \multicolumn{5}{|c|}{ Projections } \\
\hline & & & 06/07 & 07/08 & 08/09 & $09 / 10$ & $10 / 11$ \\
\hline Trade balance & $-3,297$ & $-2,879$ & $-3,426$ & $-4,383$ & $-4,930$ & $-5,201$ & $-5,401$ \\
\hline Exports (f.o.b) & 8,573 & 10,422 & 12,003 & 13,206 & 14,506 & 15,926 & 17,501 \\
\hline Of which: RMG sector & 6,418 & 7,901 & 9,165 & 10,081 & 11,049 & 12,099 & 13,260 \\
\hline Imports (f.o.b) & $-11,870$ & $-13,301$ & $-15,429$ & $-17,589$ & $-19,436$ & $-21,127$ & $-22,902$ \\
\hline Of which: Crude petroleum and petroleum products & $-1,602$ & $-2,004$ & $-2,324$ & $-2,650$ & $-2,928$ & $-3,182$ & $-3,450$ \\
\hline Services & -870 & $-1,110$ & $-1,385$ & $-1,699$ & $-1,954$ & $-2,185$ & $-2,429$ \\
\hline Income & -680 & -786 & -929 & -872 & -944 & -936 & -928 \\
\hline Transfers & 4,290 & 5,347 & 6,033 & 6,495 & 6,884 & 7,228 & 7,523 \\
\hline Of which: Workers' remittances & 3,851 & 4,802 & 5,585 & 6,032 & 6,393 & 6,713 & 6,982 \\
\hline Current account balance & -557 & 572 & 293 & -459 & -944 & $-1,095$ & $-1,235$ \\
\hline Capital and financial account balance & 624 & -207 & -93 & 1,205 & 1,693 & 1,981 & 2,193 \\
\hline Capital account & 163 & 242 & 250 & 469 & 478 & 488 & 493 \\
\hline Financial account & 461 & -449 & -343 & 736 & 1,215 & 1,493 & 1,700 \\
\hline Foreign direct investment & 776 & 675 & 730 & 789 & 862 & 940 & 1,026 \\
\hline Portfolio investment & 0 & 32 & 20 & 0 & 0 & 0 & 0 \\
\hline Net aid flows $2 /$ & 491 & 432 & 469 & 725 & 955 & 1,126 & 1,300 \\
\hline Aid disbursements & 940 & 921 & 933 & 1,239 & 1,491 & 1,712 & 1,900 \\
\hline Debt amortization & -449 & -489 & -464 & -515 & -536 & -586 & -600 \\
\hline Other capital 3/ & -806 & $-1,588$ & $-1,562$ & -778 & -602 & -573 & -626 \\
\hline Overall balance & -232 & 365 & 200 & 745 & 749 & 887 & 958 \\
\hline Financing items & 232 & -365 & -200 & -745 & -749 & -887 & -958 \\
\hline Bangladesh Bank & -67 & -365 & -200 & -745 & -749 & -887 & -958 \\
\hline Assets (- increase) & -225 & -554 & -407 & -745 & -735 & -851 & -905 \\
\hline Liabilities $4 /$ & 158 & 189 & 207 & 0 & -14 & -36 & -53 \\
\hline \multicolumn{8}{|l|}{ Memorandum items: } \\
\hline Current account balance (percent of GDP) & -0.9 & 0.9 & 0.4 & -0.6 & -1.2 & -1.3 & -1.3 \\
\hline Export growth rate (percent) & 14.0 & 23.1 & 15.2 & 10.0 & 9.8 & 9.8 & 9.9 \\
\hline Import growth rate (percent) & 20.6 & 12.1 & 16.0 & 14.0 & 10.5 & 8.7 & 8.4 \\
\hline Gross official reserves (US\$ million) 4/ & 2,930 & 3,424 & 3,831 & 4,576 & 5,311 & 6,162 & 7,067 \\
\hline (In months of imports of goods and services) & 2.5 & 2.6 & 2.5 & 2.7 & 2.8 & 3.0 & 3.1 \\
\hline Net international reserves (US\$ million) & 2,046 & 2,221 & 2,421 & 3,166 & 3,916 & 4,802 & 5,760 \\
\hline Net aid flows/GDP & $1.2 \%$ & $1.1 \%$ & $1.2 \%$ & $1.7 \%$ & $1.8 \%$ & $1.9 \%$ & $1.9 \%$ \\
\hline Nominal GDP (US\$ million) & 60,314 & 62,033 & 66,504 & 72,912 & 80,049 & 87,369 & 94,680 \\
\hline
\end{tabular}

Sources: Data provided by the Bangladesh authorities; and IMF staff estimates and projections.

1/ Fiscal year begins July 1.

2/ Loans only. For FY05 includes flood-related donor assistance of US\$123 million, plus World Bank loans.

(DSC II and education) totaling another US $\$ 300$ million that were originally planned for FY04.

3 / Includes trade credits, long-term borrowing, short-term financing for BPC, commercial bank net borrowing, and errors and omissions.

4/ Includes Asian Clearing Union balances. 


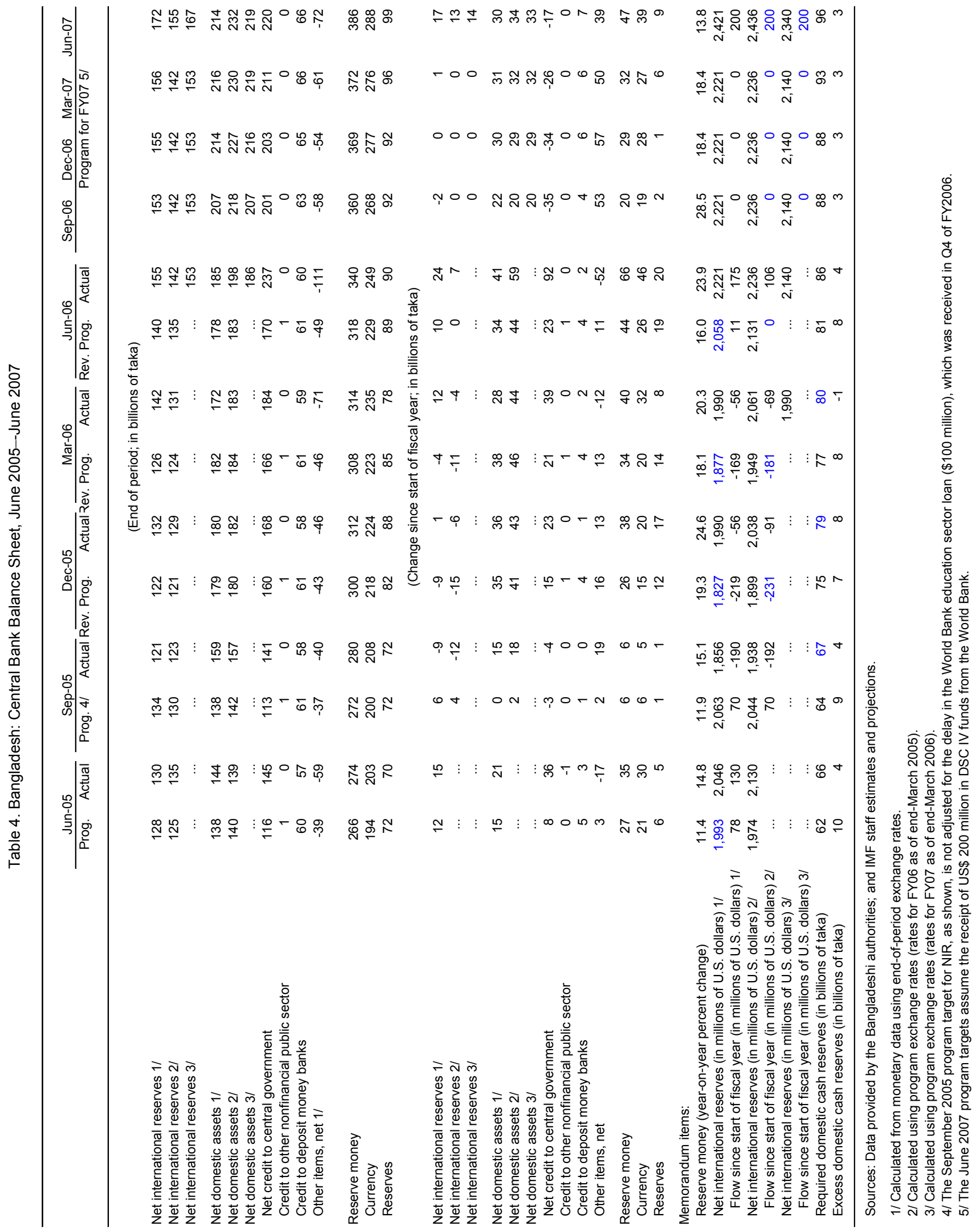




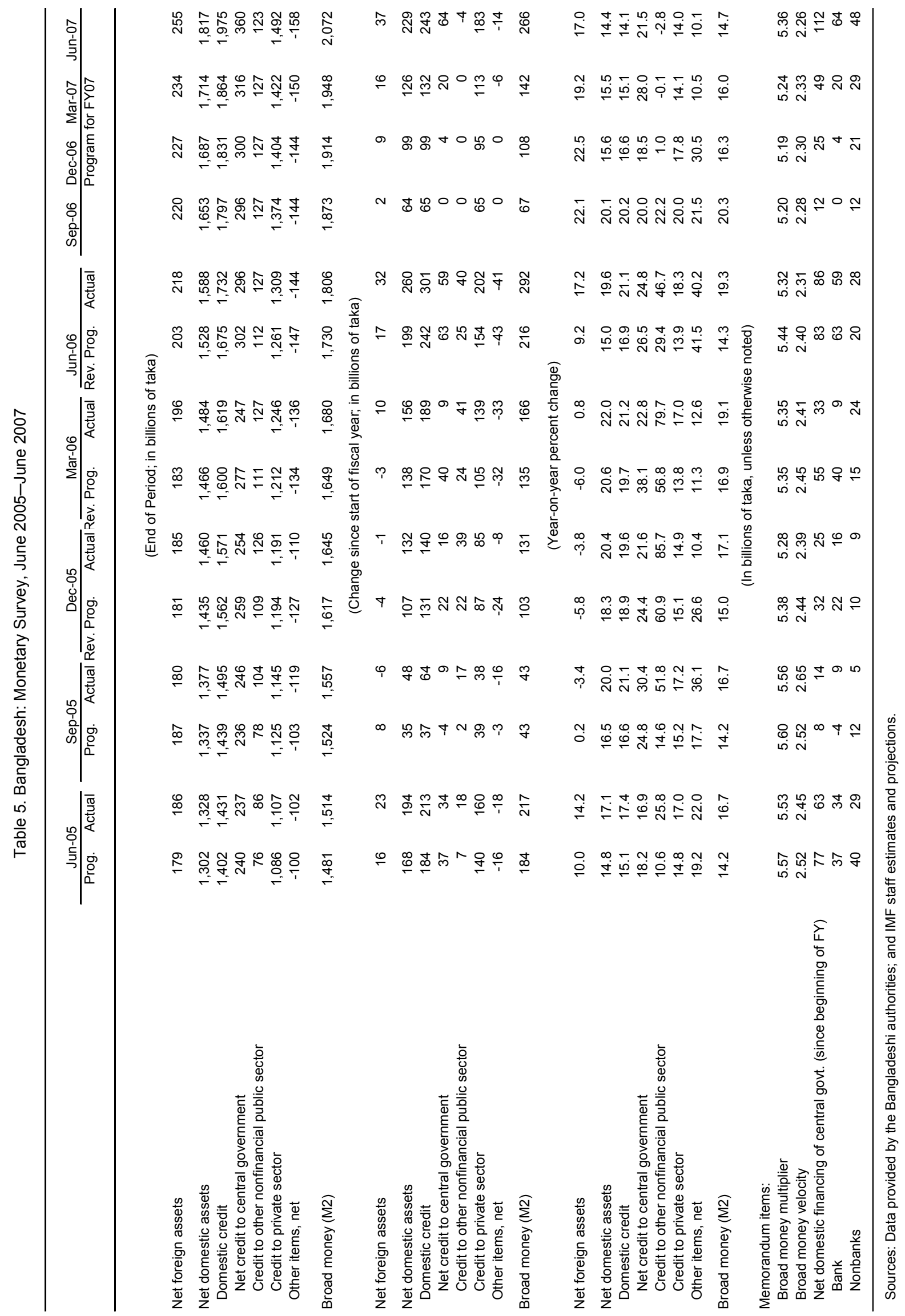


Table 6. Bangladesh: Central Government Operations, FY04-08 1/

\begin{tabular}{|c|c|c|c|c|c|c|c|c|}
\hline & \multirow[t]{2}{*}{$2003 / 04$} & \multirow[t]{2}{*}{$2004 / 05$} & \multicolumn{3}{|c|}{$2005 / 06$} & \multicolumn{2}{|c|}{$2006 / 07$} & \multirow{2}{*}{$\frac{2007 / 08}{\text { Proj. }}$} \\
\hline & & & Budget & $\begin{array}{l}\text { Rev. prog. } \\
\text { Nov. } 2005\end{array}$ & Est. & Budget & $\begin{array}{l}\text { IMF } \\
\text { rojection }\end{array}$ & \\
\hline & \multicolumn{8}{|c|}{ (In billions of taka) } \\
\hline Total revenue & 339.0 & 389.2 & 457.2 & 457.2 & 443.7 & 525.4 & 512.7 & 595.2 \\
\hline Tax revenue & 274.3 & 314.1 & 373.1 & 373.1 & 354.2 & 429.2 & 412.6 & 493.0 \\
\hline NBR taxes & 261.9 & 299.9 & 356.5 & 356.5 & 338.9 & 410.6 & 394.0 & 469.9 \\
\hline VAT, supplementary duties, excises & 141.0 & 161.6 & 192.4 & 192.4 & 182.9 & 226.2 & 216.5 & 260.7 \\
\hline Customs duties & 70.9 & 79.1 & 91.0 & 91.0 & 78.4 & 94.9 & 79.6 & 95.0 \\
\hline Taxes on income and profits & 47.1 & 56.7 & 69.6 & 69.6 & 71.5 & 85.0 & 94.0 & 110.1 \\
\hline Other NBR taxes & 2.9 & 2.6 & 3.5 & 3.5 & 6.2 & 4.5 & 4.0 & 4.1 \\
\hline Non-NBR taxes & 12.4 & 14.2 & 16.6 & 16.6 & 15.3 & 18.6 & 18.6 & 23.1 \\
\hline Nontax revenue & 64.7 & 75.1 & 84.1 & 84.1 & 89.5 & 96.3 & 100.1 & 102.2 \\
\hline Total expenditure & 434.8 & 513.9 & 643.8 & 623.9 & 579.3 & 697.4 & 691.2 & 781.4 \\
\hline Current expenditure & 258.6 & 312.5 & 361.8 & 361.8 & 350.4 & 403.0 & 428.2 & 435.5 \\
\hline Pay and allowances & 76.6 & 84.2 & 98.8 & 98.8 & 100.4 & 117.2 & 117.2 & 122.2 \\
\hline Goods and services & 45.1 & 56.4 & 57.6 & 57.6 & 60.7 & 63.9 & 70.0 & 77.3 \\
\hline Interest payments & 54.5 & 61.8 & 70.5 & 73.5 & 75.1 & 76.4 & 76.0 & 90.3 \\
\hline Subsidies and transfers & 78.9 & 103.2 & 117.1 & 117.1 & 108.6 & 125.5 & 161.9 & 130.0 \\
\hline Subsidies & 11.9 & 21.6 & 16.9 & 16.9 & 16.9 & 17.3 & 59.7 & 21.4 \\
\hline Transfers & 67.0 & 81.6 & 100.2 & 100.2 & 91.7 & 108.3 & 102.1 & 108.6 \\
\hline Block allocations & 3.6 & 6.9 & 17.8 & 14.8 & 5.7 & 20.0 & 3.1 & 15.7 \\
\hline Food account surplus(-)/deficit(+) & 3.5 & 0.6 & 1.7 & 1.7 & -1.2 & 2.0 & 2.5 & 5.2 \\
\hline Annual Development Program & 167.9 & 185.8 & 245.0 & 225.0 & 194.7 & 260.0 & 227.6 & 299.8 \\
\hline Non-ADP capital spending & 26.6 & 29.5 & 27.9 & 28.3 & 38.4 & 44.5 & 42.9 & 50.6 \\
\hline Net lending & -10.6 & -5.3 & -11.6 & -0.3 & $2.92 /$ & -12.1 & -10.0 & -9.8 \\
\hline Extraordinary expenditures & 7.8 & 1.9 & 7.5 & 7.5 & 0.0 & 0.0 & 0.0 & 0.0 \\
\hline Check float plus discrepancy & -19.1 & -11.1 & 0.0 & 0.0 & -5.8 & $\ldots$ & 0.0 & 0.0 \\
\hline $\begin{array}{l}\text { Overall balance (excluding grants) } \\
\text { Primary balance (excluding grants) }\end{array}$ & $\begin{array}{l}-95.7 \\
-41.2\end{array}$ & $\begin{array}{r}-124.7 \\
-62.9\end{array}$ & $\begin{array}{l}-186.6 \\
-116.1\end{array}$ & $\begin{array}{r}-166.7 \\
-93.2\end{array}$ & $\begin{array}{r}-135.6 \\
-60.6\end{array}$ & $\begin{array}{r}-172.0 \\
-95.6\end{array}$ & $\begin{array}{l}-178.5 \\
-102.5\end{array}$ & $\begin{array}{r}-186.2 \\
-95.9\end{array}$ \\
\hline Net financing & 95.7 & 124.7 & 186.6 & 166.7 & 135.6 & 172.0 & 178.5 & 186.2 \\
\hline External & 35.9 & 60.9 & 103.2 & 83.7 & 49.3 & 83.7 & 55.2 & 90.6 \\
\hline Domestic & 59.8 & 63.8 & 83.4 & 83.0 & 86.4 & 88.3 & 111.7 & 95.6 \\
\hline Banks & 13.4 & 35.0 & 36.4 & 63.0 & $58.82 /$ & 54.3 & 64.0 & 63.7 \\
\hline Nonbanks & 46.4 & 28.8 & 47.0 & 20.0 & 27.6 & 34.0 & 47.7 & 31.9 \\
\hline \multirow[t]{2}{*}{ Privatization receipts } & 0.0 & 0.0 & 0.0 & 0.0 & 0.0 & 0.0 & 11.6 & 0.0 \\
\hline & \multicolumn{8}{|c|}{ (In percent of GDP) } \\
\hline Total revenue & 10.2 & 10.5 & 11.0 & 11.0 & 10.6 & 11.3 & 11.0 & 11.4 \\
\hline Tax revenue & 8.2 & 8.5 & 8.9 & 9.0 & 8.5 & 9.2 & 8.8 & 9.4 \\
\hline NBR taxes & 7.9 & 8.1 & 8.5 & 8.6 & 8.1 & 8.8 & 8.4 & 9.0 \\
\hline Non-NBR taxes & 0.4 & 0.4 & 0.4 & 0.4 & 0.4 & 0.4 & 0.4 & 0.4 \\
\hline Nontax revenue & 1.9 & 2.0 & 2.0 & 2.0 & 2.1 & 2.1 & 2.1 & 2.0 \\
\hline Total expenditure & 13.1 & 13.9 & 15.5 & 15.1 & 13.9 & 15.0 & 14.8 & 14.9 \\
\hline Current expenditure & 7.8 & 8.4 & 8.7 & 8.7 & 8.4 & 8.7 & 9.1 & 8.3 \\
\hline Pay and allowances & 2.3 & 2.3 & 2.4 & 2.4 & 2.4 & 2.5 & 2.5 & 2.3 \\
\hline Goods and services & 1.4 & 1.5 & 1.4 & 1.4 & 1.5 & 1.4 & 1.5 & 1.5 \\
\hline Interest & 1.6 & 1.7 & 1.7 & 1.8 & 1.8 & 1.6 & 1.6 & 1.7 \\
\hline Subsidies and transfers & 2.4 & 2.8 & 2.8 & 2.8 & 2.6 & 2.7 & 3.5 & 2.5 \\
\hline Subsidies & 0.4 & 0.6 & 0.4 & 0.4 & 0.4 & $\ldots$ & 1.3 & 0.4 \\
\hline Transfers & 2.0 & 2.2 & 2.4 & 2.4 & 2.2 & & 2.2 & 2.1 \\
\hline Block allocations & 0.1 & 0.2 & 0.4 & 0.4 & 0.1 & 0.4 & 0.1 & 0.3 \\
\hline Annual Development Program & 5.0 & 5.0 & 5.9 & 5.4 & 4.7 & 5.6 & 4.9 & 5.7 \\
\hline Non-ADP capital spending & 0.8 & 0.8 & 0.7 & 0.7 & 0.9 & 1.0 & 0.9 & 1.0 \\
\hline Net lending & -0.3 & -0.1 & -0.3 & 0.0 & $0.12 /$ & -0.3 & -0.2 & -0.2 \\
\hline Other expenditures & 0.3 & 0.1 & 0.2 & 0.2 & 0.0 & 0.0 & 0.1 & 0.1 \\
\hline Check float plus discrepancy & -0.6 & -0.3 & 0.0 & 0.0 & -0.1 & $\ldots$ & 0.0 & 0.0 \\
\hline Overall balance (excluding grants) & -2.9 & -3.4 & -4.5 & -4.0 & -3.3 & -3.7 & -3.8 & -3.6 \\
\hline Primary balance (excluding grants) & -1.2 & -1.7 & -2.8 & -2.3 & -1.5 & -2.1 & -2.2 & -1.8 \\
\hline Net financing & 2.9 & 3.4 & 4.5 & 4.0 & 3.3 & 3.7 & 3.8 & 3.6 \\
\hline External & 1.1 & 1.6 & 2.5 & 2.0 & 1.2 & 1.8 & 1.2 & 1.7 \\
\hline Domestic & 1.8 & 1.7 & 2.0 & 2.0 & 2.1 & 1.9 & 2.4 & 1.8 \\
\hline Banks & 0.4 & 0.9 & 0.9 & 1.5 & $1.42 /$ & 1.2 & 1.4 & 1.2 \\
\hline Nonbanks & 1.4 & 0.8 & 1.1 & 0.5 & 0.7 & 0.7 & 1.0 & 0.6 \\
\hline Privatization receipts & 0.0 & 0.0 & 0.0 & 0.0 & 0.0 & $\ldots$ & 0.2 & 0.0 \\
\hline \multicolumn{9}{|l|}{ Memorandum items: } \\
\hline Nominal GDP (in billions of taka) & 3,330 & 3,707 & 4,171 & 4,142 & 4,166 & 4,653 & 4,682 & 5,235 \\
\hline Overall balance, including grants & -2.4 & -3.0 & -3.7 & -3.4 & -2.8 & -3.2 & -3.3 & -2.8 \\
\hline Poverty reducing spending & 6.4 & 6.7 & 8.4 & 8.4 & 7.8 & 8.4 & 8.4 & 8.9 \\
\hline Government wage bill and pensions & 3.7 & 3.8 & 3.8 & 3.8 & 3.5 & 3.8 & 3.8 & 3.7 \\
\hline Total central government debt & 48.7 & 47.6 & $\ldots$ & 48.5 & 46.9 & $\ldots$ & 45.7 & 44.1 \\
\hline Net profits and losses of nonfinancial public enterprises $3 /$ & -0.2 & -0.8 & $\ldots$ & $\ldots$ & -1.0 & $\ldots$ & $\ldots$ & $\ldots$ \\
\hline
\end{tabular}

Sources: Data provided by the Bangladesh authorities; and IMF staff estimates.

1/ Fiscal year ends June 30

2/ Includes bonds (10 billion taka) issued to a nationalized commercial bank to assume a state-owned petroleum company's borrowings $3 /$ Accrual basis. 
Table 7. Bangladesh: Proposed Schedule of Disbursements Under the PRGF Arrangement and Augmentation of PRGF Access in Accordance with the Trade Integration Mechanism (TIM)

\begin{tabular}{|c|c|c|c|c|}
\hline Original Amount & Augmentation & Total & Available Date & Conditions for Disbursement \\
\hline $\begin{array}{l}\text { SDR } 49.5 \text { million } \\
\text { (9.3 percent of quota) }\end{array}$ & & $\begin{array}{l}\text { SDR } 49.5 \text { million } \\
\text { (9.3 percent of quota) }\end{array}$ & June 20, 2003 & $\begin{array}{l}\text { Observance of the end-March } 2003 \text { quantitative } \\
\text { benchmark, implementation of prior actions, and Board } \\
\text { approval of arrangement. }\end{array}$ \\
\hline $\begin{array}{l}\text { SDR } 49.5 \text { million } \\
\text { ( } 9.3 \text { percent of quota) }\end{array}$ & & $\begin{array}{l}\text { SDR } 49.5 \text { million } \\
\text { (9.3 percent of quota) }\end{array}$ & December 15, 2003 & $\begin{array}{l}\text { Observance of the end-September } 2003 \text { performance } \\
\text { criteria and structural performance criteria for end- } \\
\text { September and end-November } 2003 \text { and completion of } \\
\text { the first review. }\end{array}$ \\
\hline $\begin{array}{l}\text { SDR } 49.5 \text { million } \\
\text { (9.3 percent of quota) }\end{array}$ & & $\begin{array}{l}\text { SDR } 49.5 \text { million } \\
\text { ( } 9.3 \text { percent of quota) }\end{array}$ & July 28, 2004 & $\begin{array}{l}\text { Observance of the end-March } 2004 \text { performance criteria } \\
\text { and structural performance criteria for end-December } \\
2003 \text { and end-April } 2004 \text { and completion of the second } \\
\text { review. }\end{array}$ \\
\hline $\begin{array}{l}\text { SDR } 49.5 \text { million } \\
\text { (9.3 percent of quota) }\end{array}$ & $\begin{array}{l}\text { SDR } 17.78 \text { million } \\
\text { (3.33 percent of quota) }\end{array}$ & $\begin{array}{l}\text { SDR } 67.28 \text { million } \\
\text { (12.63 percent of quota) }\end{array}$ & June 29, 2005 & $\begin{array}{l}\text { Observance of the end-September } 2004 \text { performance } \\
\text { criteria and structural performance criteria for end- } \\
\text { September and end-November } 2004 \text {, implementation of } \\
\text { prior actions, and completion of the third review. }\end{array}$ \\
\hline $\begin{array}{l}\text { SDR } 49.5 \text { million } \\
\text { ( } 9.3 \text { percent of quota) }\end{array}$ & $\begin{array}{l}\text { SDR } 17.78 \text { million } \\
\text { (3.33 percent of quota) }\end{array}$ & $\begin{array}{l}\text { SDR } 67.28 \text { million } \\
\text { (12.63 percent of quota) }\end{array}$ & February 15, 2006 & $\begin{array}{l}\text { Observance of the end-September } 2005 \text { performance } \\
\text { criteria and completion of the fourth review. }\end{array}$ \\
\hline $\begin{array}{l}\text { SDR } 15.9 \text { million } \\
\text { (2.98 percent of quota) }\end{array}$ & $\begin{array}{l}\text { SDR } 17.78 \text { million } \\
\text { (3.33 percent of quota) }\end{array}$ & $\begin{array}{l}\text { SDR } 33.67 \text { million } \\
\text { (6.32 percent of quota) }\end{array}$ & October 24, 2006 & $\begin{array}{l}\text { Observance of the end-March } 2006 \text { performance criteria } \\
\text { and completion of the fifth review. }\end{array}$ \\
\hline $\begin{array}{l}\text { SDR } 83.6 \text { million } \\
\text { (15.68 percent of quota) }\end{array}$ & & $\begin{array}{l}\text { SDR } 83.6 \text { million } \\
\text { (15.68 percent of quota) }\end{array}$ & June 15, 2007 & $\begin{array}{l}\text { Observance of the end-December } 2006 \text { performance } \\
\text { criteria and completion of the sixth review. }\end{array}$ \\
\hline $\begin{array}{l}\text { Total } \\
\text { SDR } 347.0 \text { million } \\
\text { (65 percent of quota) }\end{array}$ & $\begin{array}{l}\text { SDR } 53.33 \text { million } \\
\text { (10 percent of quota) }\end{array}$ & $\begin{array}{l}\text { SDR } 400.33 \text { million } \\
\text { ( } 75 \text { percent of quota) }\end{array}$ & & \\
\hline
\end{tabular}




\title{
ANNEX I. BANGLADESh: JoInt IMF-WorLd BANK DEbT SUSTAINABILITY ANALYSIS
}

\begin{abstract}
Bangladesh's risk of debt distress is low based on external debt indicators, but taking into account results from the public sector debt sustainability analysis (DSA), staff categorizes the overall risk of debt distress as moderate. Bangladesh's external debt burden indicators do not breach the relevant policy-dependent indicative thresholds ${ }^{1}$ under the baseline scenario, standard alternative scenarios and boundary tests, as well as two country-specific boundary scenarios. Nevertheless, debt burden indicators are significantly worse in the public sector DSA — which includes domestic debt — and the staff will monitor closely the evolution of domestic debt and the government's ability to mobilize domestic resources.
\end{abstract}

This DSA has been prepared jointly by World Bank and IMF staffs using the debt sustainability framework for low income countries approved by the Boards of both institutions (LIC DSF). The DSA is based on macroeconomic data gathered in the context of two IMF missions to Dhaka in 2006. Estimated debt outstanding and disbursed as of endFY2005 provides the basis for debt figures. ${ }^{23}$

Box 1 summarizes the medium-term macroeconomic framework underlying the DSA. Most notably, it is based on projections for growth that are in line with (but slightly lower than) those in the country's PRSP, and estimates of external assistance that reflect both expected scaling up in the context of the millennium development goals (MDGs), as well as the country's ability to absorb additional external financing. Export growth rates are conservative compared to recent trends, but the high share of garment exports (about 75 percent of the total) combined with the projected end of temporary protection against

\footnotetext{
${ }^{1}$ The low-income country debt sustainability framework (LIC DSF) provides indicative levels (thresholds) of debt burdens beyond which a country's risk of debt distress reaches levels that are considered unacceptable. The LIC DSF recognizes that better policies and institutions allow countries to manage higher levels of debt, and thus the threshold levels are policy-dependent. Bangladesh's policies and institutions, as measured by the World Bank's Country Policy and Institutional Assessment (CPIA), place it as a "medium performer." The relevant indicative thresholds for this category are: 40 percent for the NPV of debt-to-GDP ratio, 150 percent for the NPV of debt-to-exports ratio, 250 percent for the NPV of debt-to-revenue ratio, 20 percent for the debt service-to-exports ratio and 30 percent for the debt service-to-revenue ratio. These thresholds are applicable to public and publicly guaranteed external debt.

2 The fiscal year runs from July 1 to June 30.

${ }^{3}$ For creditors other than the IDA and the IMF, end-FY 2005 debt outstanding and disbursed was estimated based on end-December 2004 debt data gathered in the context of the HIPC-ring fencing ("Heavily Indebted Poor Countries (HIPC Initiative) — List of Ring-Fenced Countries that Meet the Income and Indebtedness Criteria at end-2004," April 12, 2006, www.imf.org, and IDA/R2006-0041/2). This assumption is not expected to have a material impact on this DSA. For example, the NPV of new borrowing from the Asian Development Bank during the first half of 2005 is estimated at US\$45 million, or 0.5 percent of the overall NPV of debt.
} 
Chinese garments in the US market (which absorbs 40 percent of Bangladesh's garment exports) by end-2008 has led staffs to consider a stress test with substantially lower export growth rates.

\section{Box 1. Macroeconomic Assumptions Underlying the DSA}

The macroeconomic assumptions are as follows:

Real GDP growth is, at about 6.5 percent, above the recent historical average of 5.3 percent, picking up a bit in the outer years. This is close to (but slightly lower than) Bangladesh's PRSP projections, and assumes continued progress in broad-based structural reforms and increased openness of the economy that should allow Bangladesh to benefit from dynamic growth elsewhere in the Asian region.

Inflation, as measured by the GDP deflator, decreases in the short term and stabilizes at around 2 percent.

The growth of exports and imports is strong over the projection period (averaging between 9 percent and 10 percent) as both remain constant as shares of GDP. The risk of lower exports is taken into account as a separate scenario.

The current account deficit (including grants) increases gradually over the projection period and stabilizes in the outer years at just above 2 percent of GDP, as a result primarily of continued strong growth of capital and intermediate goods imports related to increasing investment projects.

Net aid inflows gradually increase and stabilize in the range of 2 percent of GDP (consistent with Bangladesh's PRSP). The projections assume that grants comprise a decreasing percent of total aid disbursements over the 25 -year period, ranging from 34 percent at the beginning to 10 percent at the end. Standard terms were used for new borrowings (e.g., for IDA disbursements, 0.75 percent interest rate, 10 -year grace period, and 40-year maturity).

The primary fiscal deficit is assumed to remain largely unchanged and close to the historical average (around 1.5 percent of GDP for FY2006-26). A modest rise is assumed in the revenue-to-GDP ratio (excluding grants) in the initial years (from 10.5 percent in FY2005 to 12.0 percent in FY2011), supported by efforts to mobilize domestic revenues.

Real interest rates on domestic currency debt are assumed somewhat higher than the historical average consistent with the expected decrease in the inflation rate.

\section{External debt sustainability analysis}

\section{All external debt indicators remain well below the policy-dependent debt burden thresholds under the baseline scenario and standard stress tests. The main results of the external DSA are as follows:}

\footnotetext{
- All debt indicators in the baseline scenario are expected to decline over the 20-year projection period (Table A1 and Figure A1). The NPV of debt-to-GDP ratio decreases from about 17 percent to 15 percent (compared to an indicative threshold of 40 percent) during the projection period, while the NPV debt-to-exports ratio
} 
decreases from about 92 percent to 68 percent (compared to an indicative threshold of 150 percent), and the debt- service ratio decreases from over 5 percent to about 4 percent (compared to an indicative threshold of 20 percent).

- The standard stress tests do not reveal any serious vulnerability as all ratios remain well below the indicative debt-burden thresholds (Table A2 and Figure A1).

- The table below summarizes Bangladesh's indicative thresholds, actual 2005 ratios, and average debt ratios under the baseline scenario.

Policy-Based External Debt Burden Thresholds for Bangladesh

\begin{tabular}{lccc}
\hline & Thresholds & \multicolumn{2}{c}{ Bangladesh's Ratios } \\
& & 2005 & 2006-26 1/ \\
\hline NPV of debt in percent of & 40 & 17 & 15 \\
GDP & 150 & 106 & 74 \\
Exports & & & \\
Debt service in percent of & & 6 & 5 \\
$\quad$ Exports & 20 & &
\end{tabular}

1/ Average for the period.

Standard shocks and bound tests are generally appropriate for Bangladesh. Although the volatility of Bangladesh's growth rates in the past decade was exceptionally low, even a two-standard deviation temporary shock would not cause a serious deterioration of external debt ratios. In the absence of key structural reforms, however, long-term growth could be significantly lower and thus staff considered such a scenario as a boundary case. Special attention was paid to export growth, which is viewed as the country's main vulnerability from an external debt sustainability perspective, and a more stringent bound test was added. Risks to the exchange rate and foreign financing are low, and the standard stress tests are appropriate. Finally, despite vulnerability to natural disasters, Bangladesh's economy has been increasingly resilient to those risks and they are not considered by staff to be a source of concern in the DSA.

\section{An alternative boundary scenario was calculated using substantially lower export growth rates over an extended period, but debt levels remained below indicative thresholds under reasonable assumptions. Although export performance has continued to be strong despite the increased competition following the expiration of ATC quotas in 2005, the full impact of this development might only be seen from 2008 onwards, when the temporary quotas for China will expire. Since exports are concentrated in the ready-made garments (RMG) sector (such exports amount to about 75 percent of Bangladesh's total exports), there are risks to the baseline export growth projections. Staff assesses that if the threat of competition from China materializes, the export growth rate could fall to as low as 5 percent per year, or about one standard deviation from the historical average. Accordingly,}


we calculated a scenario where export growth falls to that level for the first ten years of the projection period.

- Bangladesh's debt ratios would not cross any indicative thresholds in a scenario where the growth rate of exports falls to 5 percent per year for the next 10 years, the most extreme scenario in the staff's view.

- The export growth rate would have to fall below 3.2 percent per year for 10 years for the indicative thresholds to be breached; staffs consider this scenario highly unlikely. Even in this case, the debt-service to exports ratio would reach only 10 percent and remain well below the indicative threshold.

- A slowdown in garment exports would have a limited impact on GDP growth. The garment sector directly accounts for at most 10 percent of Bangladesh's economy (although its impact via subsidiary industries is more significant). Accordingly, even if the sector were to stagnate, the impact on GDP growth would be muted by the other, more diverse sources of growth.

Staff also considered the risks to long-term growth stemming from a failure to implement key structural reforms. There are risks that a failure to implement important structural reforms, particularly those in the power sector, could significantly depress growth rates. However, according to staff's calculations, Bangladesh's GDP would have to contract at a rate of over 3 percent per year over a 10-year period for the ratio of NPV of debt-to-GDP to exceed the indicative threshold, an implausible scenario in the staff's view.

The lower ratio of NPV of debt to exports calculated in this DSA compared to the ratio calculated during the HIPC ringfencing exercise is due primarily to methodological factors as explained in detail in Table A6 and Box 2. The ringfencing ratio was calculated under the HIPC methodology, which was designed for assessing debt relief needs and entails using currency-specific discount rates, end-2004 exchange rates, and a three-year average for exports in the denominator. Meanwhile, the LIC DSF methodology employed in the present analysis was designed to assess debt sustainability and entails using a standard 5 percent discount rate, exchange rate projections from the IMF's World Economic Outlook (WEO), and one-year exports in the denominator.

The difference in ratios due to methodological differences draws attention to the relative mismatch in the currency composition of Bangladesh's external debt and its exports. As the figure below shows, a large part (37 percent in NPV terms) of Bangladesh's liabilities are yen-denominated. However, since only 1 percent of Bangladesh's exports go to Japan, this analysis cautions that an appreciation of the Japanese yen vis-à-vis other currencies could lead to a substantial deterioration of Bangladesh's external debt ratios. 


\section{Box 2. Reconciliation of the NPV of Debt to Exports Ratios Between (i) the December 2004 HIPC Ringfencing Exercise and (ii) the June 2005 DSA}

At the time of the HIPC ringfencing exercise, Bangladesh's debt-to-exports ratio as of December 2004 was estimated as 146 percent, while using the present LIC framework methodology, this ratio is estimated to be 106 percent at June 2005. This 40 percentage point (pp) drop in the ratio is due primarily to four methodological factors:

i) a $10 \mathrm{pp}$ decrease is due to the change in the exchange rates used to calculate the projected debt service streams: projected exchange rates (from WEO) under the LIC framework versus end-2004 exchange rates under the HIPC methodology;

ii) a $17 \mathrm{pp}$ decrease is explained by the change in the discount rate used to calculate the NPV of debt: a single (5 percent) discount rate under the LIC framework versus currency-specific discount rates under the HIPC methodology;

iii) a $17 \mathrm{pp}$ decrease is due to the change in the denominator used to calculate the ratio: current exports under the LIC framework versus a three-year backward-looking average under the HIPC framework. Note that Bangladesh's exports in end-2004 were 16 percent higher than the backward-looking average; and

iv) a $7 \mathrm{pp}$ increase is due to undoing the Naples treatment to Paris Club debt that was assumed under the HIPC ringfencing exercise.

The remainder of the difference is due to economic factors (new borrowing, the increase in exports from December 2004 to June 2005), as well as data discrepancies.

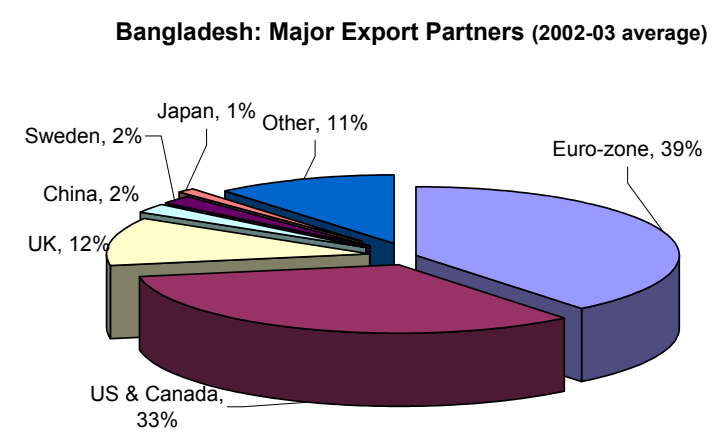

Source: IMF DOTS.

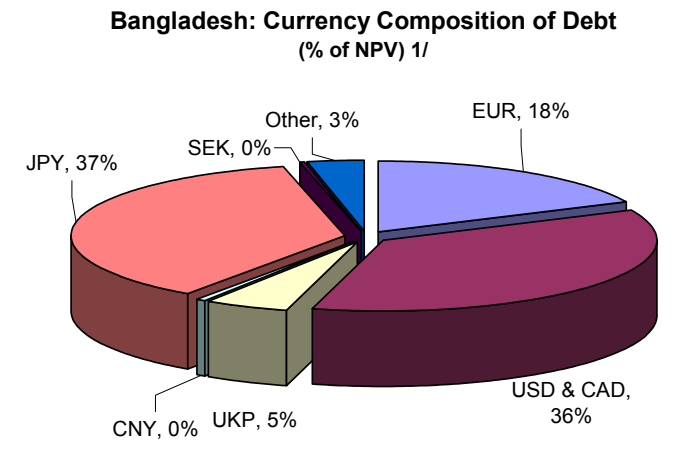

1/ SDR allocated to basket currencies using 2005 weights. 


\section{Public debt ${ }^{4}$ sustainability analysis}

Domestic debt has been relatively stable over the past five years. Gross debt has increased by less than $1 / 4$ percentage point of GDP from 18.7 percent of GDP at end-June 2002 to 18.9 percent of GDP at end-May 2006, and net debt has remained the same at 15.9 percent of GDP (Table A3). The majority of the domestic debt is in the form of treasury bills and savings certificates held by nonbanks, and just over a quarter is held by the central bank.

The baseline scenario entails a gradual decline in the NPV of public debt-to-GDP ratio, with both external and domestic debt declining relative to nominal GDP (Table A4 and Figure A2). The NPV of public debt-to-revenue ratio is also projected to decline while the debt service-to-revenue ratio remains relatively low reflecting highly concessional terms on external loans.

Despite the manageable outlook in the baseline scenario, the alternative scenarios and bound tests point to considerable risks (Table A5).

- The public debt position is vulnerable to one-off debt creating flows (scenario B5). Underpricing of energy products by BPC and BPDB, and operating losses by Biman Airlines are creating contingent liabilities that will need to be borne by the government. These contingent liabilities are presently growing by $1-1.5$ percent of GDP per annum, and in the absence of an effective strategy to address this problem, the risks of large debt-creating flows in the future are elevated. Under the assumption of a one-off debt creating flow of 10 percent of GDP — which could be conservative given that contingent liabilities will increase further unless policies are changed-the debt-service to revenue ratio reaches 47 percent in 2008, nearly 2.5 times the baseline ratio of 20 percent.

- In addition, the NPV of public debt-to-GDP ratio ceases to decline under alternative growth assumptions (scenarios A3 and B1). This is especially worrisome since a scenario of low growth is likely to be accompanied by other shocks.

The alternative scenarios and stress tests indicate that the projected paths of debt indicators are sensitive to alternative assumptions. While the historical data suggest that a deterioration of the primary balance is not a major risk, the contingent liabilities associated with quasi-fiscal activities of public enterprises are significant and, if combined with the risk

\footnotetext{
${ }^{4}$ Public debt includes domestic central government debt and external public and publicly-guaranteed debt.
} 
of lower GDP growth or a failure to improve revenue performance, would pose some risks to the sustainability of public debt.

\section{Conclusion}

It is the staffs' view that Bangladesh should be considered at low risk of debt distress based on external indicators, but the risk of debt distress is moderate once domestic obligations are included in the analysis. The baseline projections and the associated standard stress tests show little risk related to external debt given that none of the indicators breaches or is close to the indicative debt burden thresholds. However, risks to domestic revenue mobilization and domestic debt accumulation raise concerns, and as such Bangladesh is categorized as at moderate risk of debt distress overall.

The substantial increase in debt ratios when domestic debt is included, allied to concerns about contingent liabilities, calls for careful management of the public debt. While the NPV of public debt-to-revenue ratio would decline over the 20-year horizon (albeit from a relatively high level) under baseline assumptions, the ratio would remain high in some of the bound tests, highlighting the risks that can materialize if economic policies are not managed carefully and public enterprise losses are not contained.

Efforts to mobilize domestic revenues, especially in the initial years, are the key to ensure improvement in the debt indicators. This exercise also underscores the importance of effective management of the existing debt and new debt accumulation. 
Figure A1. Bangladesh: Indicators of Public and Publicly Guaranteed External Debt Under Alternative Scenarios, 2006-26
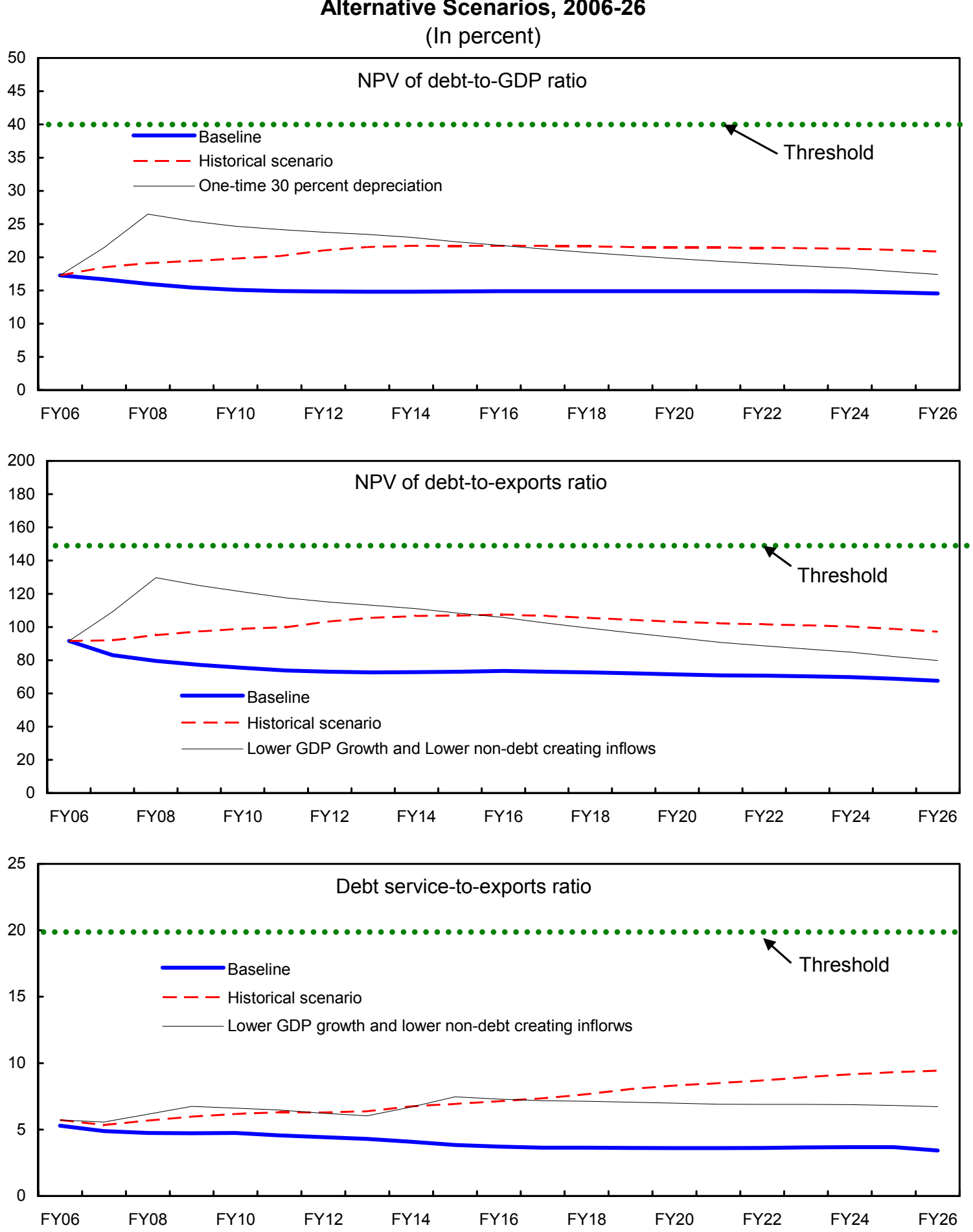

Source: IMF staff projections and simulations. 
Figure A2. Bangladesh: Indicators of Public Debt Under Alternative Scenarios FY06-26
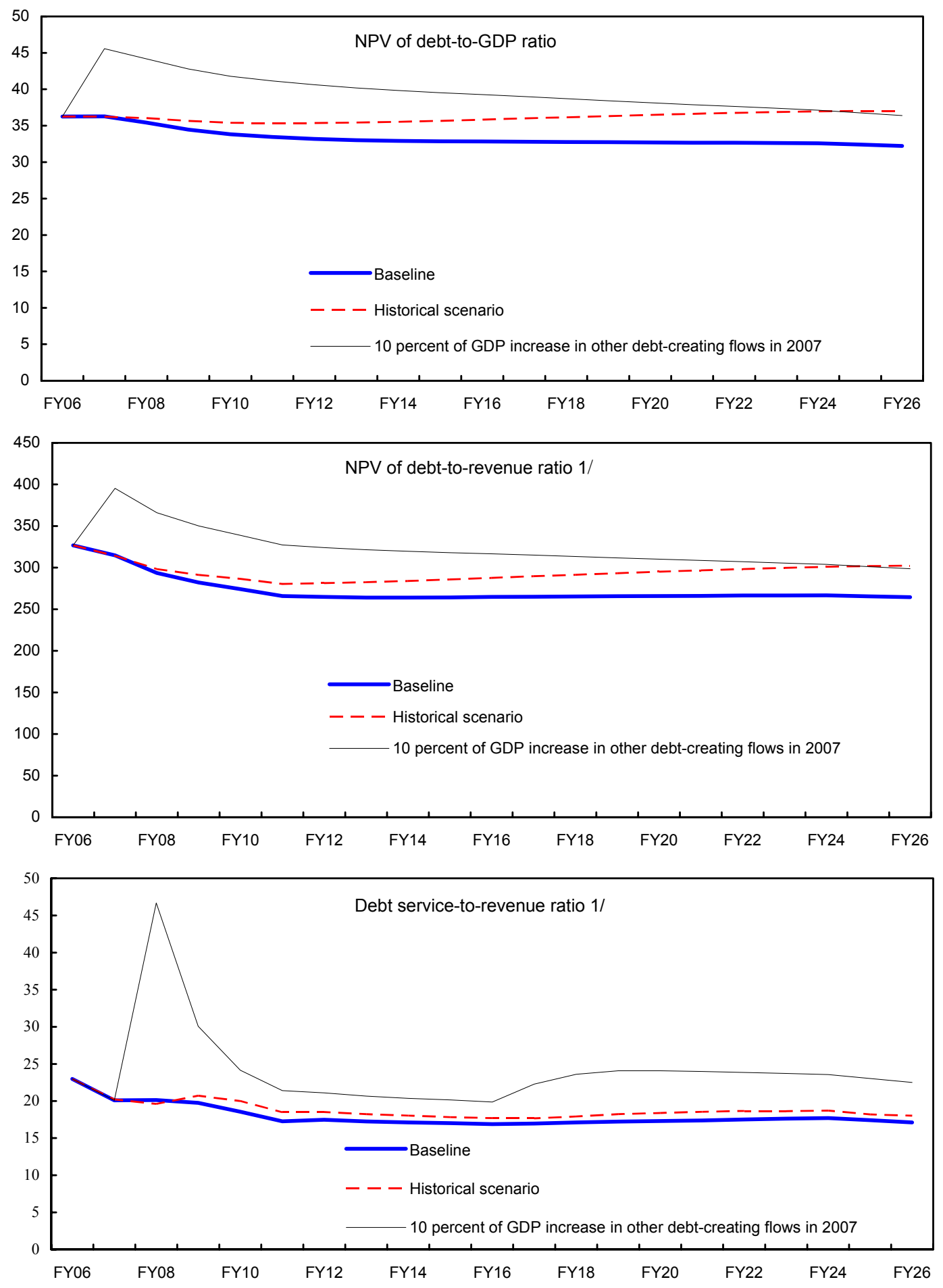

Source: IMF staff projections and simulations.

$1 /$ Revenue including grants. 


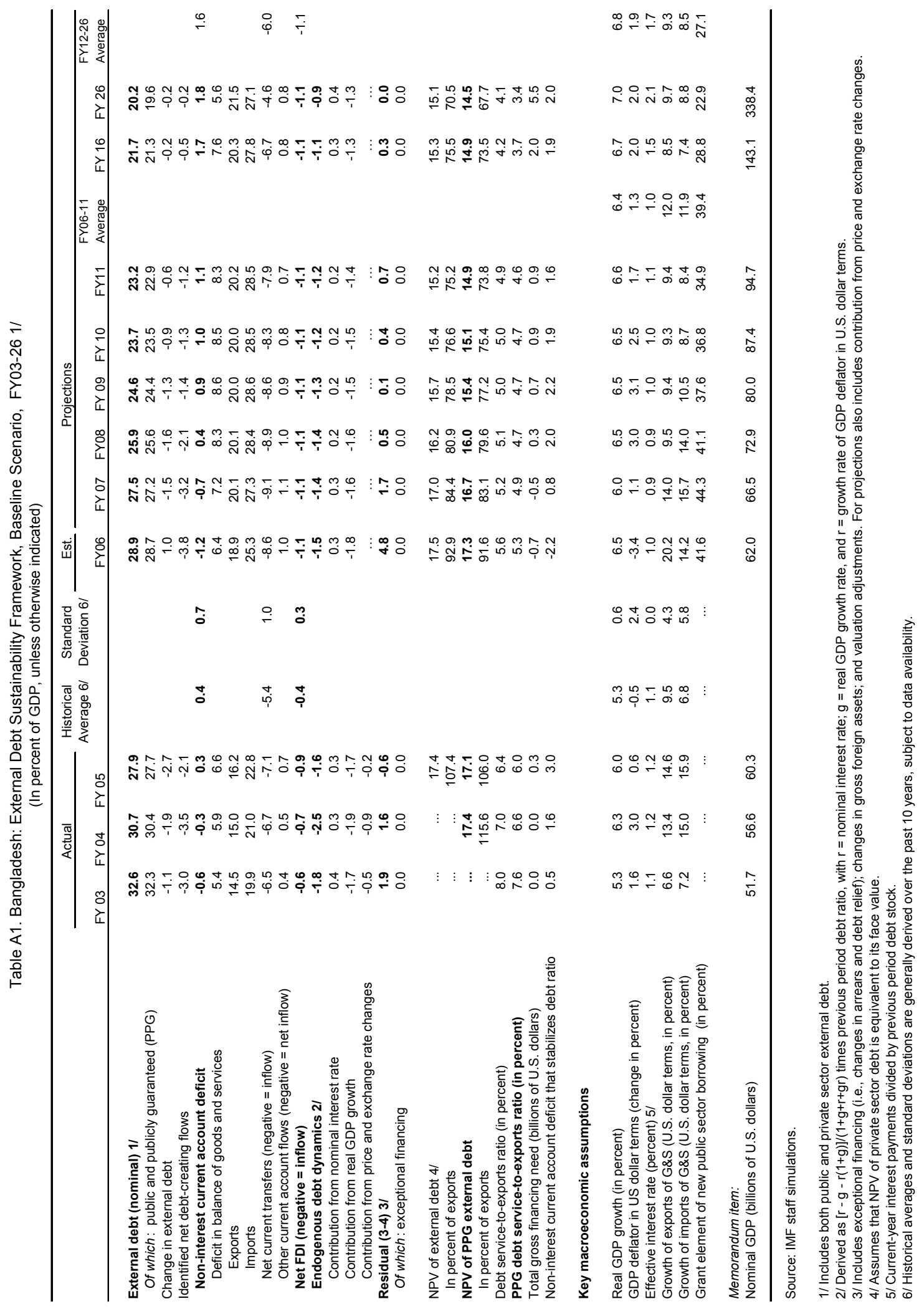


Table A2. Bangladesh: Sensitivity Analyses for Key Indicators of Public and Publicly Guaranteed External Debt, FY06-26 (In percent)

\begin{tabular}{|c|c|c|c|c|c|c|c|c|}
\hline & \multirow{2}{*}{$\begin{array}{r}\text { Est. } \\
\text { FY06 } \\
\end{array}$} & \multicolumn{7}{|c|}{ Projections } \\
\hline & & FY07 & FY08 & FY09 & FY10 & FY11 & FY16 & $\overline{\text { FY26 }}$ \\
\hline \multicolumn{9}{|c|}{ NPV of debt-to-GDP ratio } \\
\hline Baseline & 17 & 17 & 16 & 15 & 15 & 15 & 15 & 15 \\
\hline \multicolumn{9}{|l|}{ A. Alternative Scenarios } \\
\hline A1. Key variables at their historical averages in $2007-26$ 1/ & 17 & 18 & 19 & 19 & 20 & 20 & 22 & 21 \\
\hline A2. New public sector loans on less favorable terms in $2007-262 /$ & 17 & 17 & 17 & 17 & 17 & 17 & 19 & 21 \\
\hline \multicolumn{9}{|l|}{ B. Bound Tests } \\
\hline B1. Real GDP growth at historical average minus one standard deviation in 2007-08 & 17 & 17 & 16 & 16 & 16 & 15 & 15 & 15 \\
\hline B2. Export value growth at historical average minus one standard deviation in 2007-08 3/ & 17 & 18 & 19 & 18 & 18 & 17 & 17 & 15 \\
\hline B3. U.S. dollar GDP deflator at historical average minus one standard deviation in 2007-08 & 17 & 17 & 18 & 17 & 17 & 16 & 16 & 16 \\
\hline B4. Net nondebt creating flows at historical average minus one standard deviation in 2007-08 4/ & 17 & 21 & 24 & 23 & 22 & 22 & 20 & 16 \\
\hline B5. Combination of B1-B4 using one-half standard deviation shocks & 17 & 21 & 26 & 25 & 25 & 24 & 22 & 17 \\
\hline B6. One-time 30 percent nominal depreciation relative to the baseline in 2007 / & 17 & 24 & 23 & 22 & 21 & 21 & 21 & 21 \\
\hline \multicolumn{9}{|c|}{ NPV of debt-to-exports ratio } \\
\hline Baseline & 92 & 83 & 80 & 77 & 75 & 74 & 73 & 68 \\
\hline \multicolumn{9}{|l|}{ A. Alternative Scenarios } \\
\hline A1. Key variables at their historical averages in $2007-26$ 1/ & 92 & 92 & 95 & 97 & 99 & 100 & 107 & 97 \\
\hline A2. New public sector loans on less favorable terms in $2007-262 /$ & 92 & 85 & 84 & 83 & 84 & 84 & 93 & 97 \\
\hline \multicolumn{9}{|l|}{ B. Bound Tests } \\
\hline B1. Real GDP growth at historical average minus one standard deviation in 2007-08 & 92 & 83 & 80 & 77 & 75 & 74 & 73 & 68 \\
\hline B2. Export value growth at historical average minus one standard deviation in 2007-08 3/ & 92 & 96 & 105 & 102 & 99 & 96 & 92 & 79 \\
\hline B3. U.S. dollar GDP deflator at historical average minus one standard deviation in 2007-08 & 92 & 83 & 80 & 77 & 75 & 74 & 73 & 68 \\
\hline B4. Net nondebt creating flows at historical average minus one standard deviation in 2007-08 4/ & 92 & 103 & 118 & 114 & 110 & 107 & 97 & 73 \\
\hline B5. Combination of B1-B4 using one-half standard deviation shocks & 92 & 109 & 130 & 125 & 121 & 118 & 106 & 80 \\
\hline B6. One-time 30 percent nominal depreciation relative to the baseline in 2007 / & 92 & 83 & 80 & 77 & 75 & 74 & 73 & 68 \\
\hline \multicolumn{9}{|c|}{ Debt service ratio } \\
\hline Baseline & 5 & 5 & 5 & 5 & 5 & 5 & 4 & 3 \\
\hline \multicolumn{9}{|l|}{ A. Alternative Scenarios } \\
\hline A1. Key variables at their historical averages in 2007-26 1/ & 6 & 5 & 6 & 6 & 6 & 6 & 7 & 9 \\
\hline A2. New public sector loans on less favorable terms in $2007-262 /$ & 6 & 5 & 5 & 5 & 5 & 5 & 5 & 7 \\
\hline \multicolumn{9}{|l|}{ B. Bound Tests } \\
\hline B1. Real GDP growth at historical average minus one standard deviation in 2007-08 & 6 & 5 & 5 & 5 & 5 & 5 & 4 & 5 \\
\hline B2. Export value growth at historical average minus one standard deviation in $2007-083$ / & 6 & 6 & 6 & 6 & 6 & 6 & 6 & 6 \\
\hline B3. U.S. dollar GDP deflator at historical average minus one standard deviation in 2007-08 & 6 & 5 & 5 & 5 & 5 & 5 & 4 & 5 \\
\hline B4. Net nondebt creating flows at historical average minus one standard deviation in 2007-08 4/ & 6 & 5 & 6 & 6 & 6 & 6 & 7 & 6 \\
\hline B5. Combination of B1-B4 using one-half standard deviation shocks & 6 & 6 & 6 & 7 & 7 & 6 & 7 & 7 \\
\hline B6. One-time 30 percent nominal depreciation relative to the baseline in $20075 /$ & 6 & 5 & 5 & 5 & 5 & 5 & 4 & 5 \\
\hline Memorandum item: & & & & & & & & \\
\hline Grant element assumed on residual financing (i.e., financing required above baseline) $6 /$ & 28 & 28 & 28 & 28 & 28 & 28 & 28 & 28 \\
\hline
\end{tabular}

Source: IMF staff projections and simulations.

1/ Variables include real GDP growth, growth of GDP deflator (in U.S. dollar terms), non-interest current account in percent of GDP, and nondebt creating flows. 2/ Assumes that the interest rate on new borrowing is by 2 percentage points higher than in the baseline., while grace and maturity periods are the same as in the baseline. 3 / Exports values are assumed to remain permanently at the lower level, but the current account as a share of GDP is assumed to return to its baseline level after the shock (implicitly assuming an offsetting adjustment in import levels).

$4 /$ Includes official and private transfers and FDI.

$5 /$ Depreciation is defined as percentage decline in dollar/local currency rate, such that it never exceeds 100 percent.

6/ Applies to all stress scenarios except for A2 (less favorable financing) in which the terms on all new financing are as specified in footnote 2. 
Table A3. Bangladesh: Domestic Debt of Central Government (End of period; billions of taka)

\begin{tabular}{|c|c|c|c|c|c|c|}
\hline & Jun-02 & Jun-03 & $\begin{array}{c}\text { Jun-04 } \\
\text { Old }\end{array}$ & $\begin{array}{l}\text { Jun-04 } \\
\text { New }\end{array}$ & Jun-05 & May-06 \\
\hline Gross domestic debt & 511.3 & 554.1 & 622.0 & 638.7 & 726.9 & 785.6 \\
\hline (in percent of GDP) & 18.7 & 18.4 & 18.7 & 19.2 & 19.6 & 18.9 \\
\hline Net domestic debt & 434.0 & 471.5 & 531.3 & 547.8 & 611.0 & 663.9 \\
\hline (in percent of GDP) & 15.9 & 15.7 & 16.0 & 16.5 & 16.5 & 15.9 \\
\hline Bangladesh Bank, net & 107.9 & 62.2 & 74.7 & 108.8 & 145.0 & 188.3 \\
\hline Of which: Treasury bills & 112.8 & 67.0 & 79.6 & 113.0 & 150.6 & 195.5 \\
\hline Of which: Saving certificate & 2.5 & 2.4 & 0.0 & 0.0 & 0.0 & 0.0 \\
\hline Government deposits & -12.0 & -11.9 & -10.1 & -10.3 & -12.4 & -12.5 \\
\hline Deposit money banks, net & 75.9 & 111.0 & 111.8 & 94.3 & 92.5 & 73.7 \\
\hline Of which: Treasury bills & 132.2 & 172.3 & 182.4 & 150.9 & 169.0 & 155.2 \\
\hline Of which: Bonds and saving certificate & 1.0 & 0.3 & 0.5 & 0.5 & 0.3 & 0.3 \\
\hline Government deposits & -65.3 & -70.7 & -80.6 & -80.6 & -103.5 & -109.1 \\
\hline Nonbanks & 250.2 & 298.4 & 344.7 & 344.7 & 373.5 & 401.9 \\
\hline Of which: Treasury bills & 0.3 & 5.2 & 10.0 & 10.0 & 11.8 & 11.5 \\
\hline Of which: Saving certificate and prize bonds & 249.9 & 293.1 & 334.4 & 334.4 & 359.5 & 387.9 \\
\hline
\end{tabular}

Sources: Bangladesh authorities; and IMF staff estimates. 


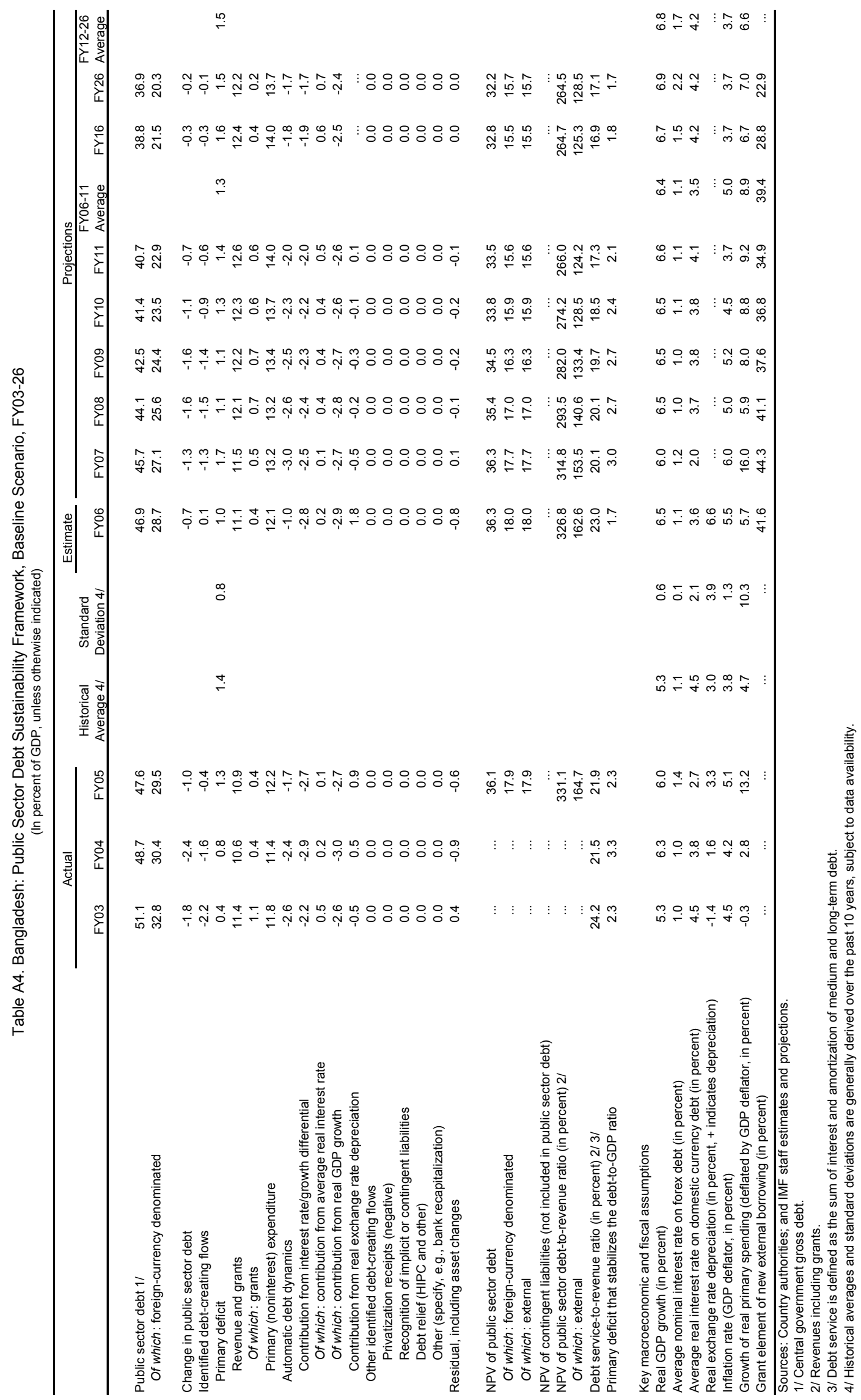


Table A5. Bangladesh: Sensitivity Analysis for Key Indicators of Public Debt FY06-26

\begin{tabular}{ll}
\hline & NPV of debt-to-GDP ratio \\
\hline Baseline &
\end{tabular}

Baseline

A. Alternative scenarios

A1. Real GDP growth and primary balance are at historical averages

A2. Primary balance is unchanged from 2006

A3. Permanently lower GDP growth $1 /$

\section{B. Bound tests}

B1. Real GDP growth is at historical average minus one standard deviations in 2007-08

B2. Primary balance is at historical average minus one standard deviations in 2007-08

B3. Combination of B1-B2 using one half standard deviation shocks

B4. One-time 30 percent real depreciation in 2007

B5. 10 percent of GDP increase in other debt-creating flows in 2007

NPV of debt-to-revenue ratio $2 /$

Baseline

A. Alternative scenarios

A1. Real GDP growth and primary balance are at historical averages

A2. Primary balance is unchanged from 2006

A3. Permanently lower GDP growth 1/

\section{B. Bound tests}

B1. Real GDP growth is at historical average minus one standard deviations in 2007-08

B2. Primary balance is at historical average minus one standard deviations in 2007-08

B3. Combination of B1-B2 using one half standard deviation shocks

B4. One-time 30 percent real depreciation in 2007

B5. 10 percent of GDP increase in other debt-creating flows in 2007

Debt service-to-revenue ratio 2 I

Baseline

$\begin{array}{llllllll}327 & 314 & 298 & 291 & 287 & 280 & 288 & 302 \\ 327 & 309 & 288 & 276 & 266 & 255 & 238 & 212 \\ 327 & 315 & 295 & 284 & 277 & 269 & 273 & 290\end{array}$

\section{A. Alternative scenarios}

A1. Real GDP growth and primary balance are at historical averages

A2. Primary balance is unchanged from 2006

A3. Permanently lower GDP growth 1/

$\begin{array}{llllllll}327 & 320 & 305 & 296 & 290 & 284 & 293 & 308 \\ 327 & 319 & 305 & 293 & 285 & 276 & 273 & 270 \\ 327 & 318 & 306 & 293 & 285 & 276 & 272 & 269 \\ 327 & 380 & 351 & 334 & 322 & 309 & 296 & 288 \\ 327 & 395 & 366 & 350 & 339 & 327 & 317 & 299\end{array}$

\section{B. Bound tests}

B1. Real GDP growth is at historical average minus one standard deviations in 2007-08

B2. Primary balance is at historical average minus one standard deviations in 2007-08

B3. Combination of B1-B2 using one half standard deviation shocks

B4. One-time 30 percent real depreciation in 2007

B5. 10 percent of GDP increase in other debt-creating flows in 2007

$\begin{array}{llllllll}36 & 36 & 35 & 34 & 34 & 33 & 33 & 32\end{array}$

$\begin{array}{llllllll}36 & 36 & 36 & 36 & 35 & 35 & 36 & 37 \\ 36 & 36 & 35 & 34 & 33 & 32 & 30 & 26\end{array}$

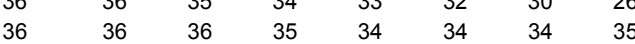

$\begin{array}{llllllll}36 & 37 & 37 & 36 & 36 & 36 & 36 & 38\end{array}$

$\begin{array}{llllllll}36 & 37 & 37 & 36 & 35 & 35 & 34 & 33\end{array}$

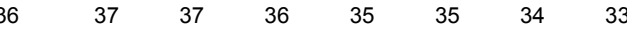

23

$\begin{array}{lllllll}20 & 20 & 20 & 19 & 17 & 17 & 17\end{array}$

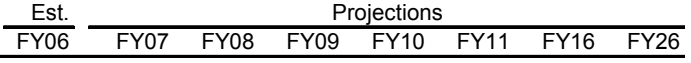

Sources: Country authorities; and IMF staff estimates and projections.

1/ Assumes that real GDP growth is at baseline minus one standard deviation divided by the square root of 20 (i.e., the length of the projection period).

2/ Revenues are defined inclusive of grants. 
Table A6: Bangladesh: Decomposition of the Decrease of the NPV of Debt-to-Exports Ratio from 146 Percent at End-December 2004 to 106 Percent at End-June 2005

(In percentage points, unless otherwise indicated)

\begin{tabular}{|c|c|c|c|c|}
\hline $\begin{array}{c}\text { Contributing factors } \\
\text { to the change in the } \\
\text { NPV of debt-to-exports ratio }\end{array}$ & $\begin{array}{l}\text { Changes } \\
\text { due to } \\
\text { methodology } 1 / \\
\end{array}$ & $\begin{array}{c}\text { Changes due } \\
\text { to economic } \\
\text { variables } \\
\end{array}$ & $2 /$ & Total \\
\hline NPV debt-to-exports ratio as at end-2004 (HIPC methodology) & 146.3 & & & 146.3 \\
\hline i) Parameters used to calculate the NPV of debt & & & & -26.4 \\
\hline Exchange rates & -9.5 & & & \\
\hline Discount rates & -16.9 & & & \\
\hline ii) New borrowing & & 1.0 & & 1.0 \\
\hline iii) Undoing hypothetical stock treatment under Naples terms & 7.5 & & & 7.5 \\
\hline iv) Exports of goods and NFS & -17.3 & -4.7 & & -22.1 \\
\hline v) Other factors $3 /$ & & -0.4 & & -0.4 \\
\hline vi) Residual 4/ & & 0.0 & & 0.0 \\
\hline NPV debt-to-exports ratio as at end-December 2004 (LIC methodology) & 110.1 & & & \\
\hline NPV debt-to-exports ratio as at end-June 2005 (LIC methodology) & & 106.0 & & 106.0 \\
\hline \multicolumn{5}{|l|}{ Memorandum item } \\
\hline Change in the NPV of debt-to-exports ratio & 36.3 & 4.1 & & 40.4 \\
\hline
\end{tabular}

1/ Corresponds to the impact of calculating the NPV of debt-to-exports ratio under the methodology proposed in the debt sustainability framework for low income countries (DSF) instead of the HIPC methodology. It also includes the impact of removing the assumption of a hypothetical debt stock reduction from bilateral and commercial creditors under Naples' terms required to assess HIPC eligibility.

2/ Corresponds to changes in the NPV of debt-to-exports ratio due to debt flows (disbursements, repayments) and changes in the export denominator between end-December 2004 and end-June 2005.

3 / Corresponds to the effect of repayments ( -3.1 percentage points) and moving the NPV reference date forward (+2.7 percentage points).

4/ The residual accounts for data discrepancies as well as rounding errors. 


\section{ANNEX II. BANGLADESh: Fund RELATIONS}

(As of August 31, 2006)

I. Membership Status: Joined August 17, 1972; accepted the obligations under Article VIII, Sections 2, 3, and 4 on April 11, 1994.

II. General Resources Account:

Quota

Fund holding of currency

Reserve position in Fund

III. SDR Department:

Net cumulative allocation

Holdings

IV. Outstanding Purchases and Loans:

PRGF arrangements $\underline{\text { SDR million }}$

533.30

533.08

0.25

$\underline{\text { SDR million }}$

47.12

0.27

$\underline{\text { SDR million }}$

283.06 $\underline{\text { Percent Quota }}$

100.00

99.96

0.05

$\underline{\text { Percent Allocation }}$

100.00

0.57

$\underline{\text { Percent Quota }}$

53.08

V. $\quad$ Financial Arrangements:

\begin{tabular}{lrrrr}
\hline Type & $\begin{array}{r}\text { Approval } \\
\text { Date }\end{array}$ & $\begin{array}{r}\text { Expiration } \\
\text { Date }\end{array}$ & $\begin{array}{r}\text { Amount approved } \\
\text { (SDR million) }\end{array}$ & $\begin{array}{r}\text { Amount drawn } \\
\text { (SDR million) }\end{array}$ \\
\hline PRGF & $6 / 20 / 03$ & $12 / 31 / 06$ & 400.33 & 283.06 \\
ESAF & $8 / 10 / 90$ & $9 / 13 / 93$ & 345.00 & 330.00 \\
SAF & $2 / 06 / 87$ & $2 / 05 / 90$ & 201.25 & 201.25
\end{tabular}

VI. Projected Payments to Fund (SDR million; based on existing use of resources and present holdings of SDRs):

\begin{tabular}{crrrrr}
\hline & 2006 & 2007 & 2008 & 2009 & 2010 \\
\hline Principal & 0.00 & 0.00 & 4.95 & 14.85 & 29.70 \\
Charges/interest & 1.17 & 3.25 & 3.25 & 3.20 & 3.07 \\
\multicolumn{1}{c}{ Total } & 1.17 & 3.25 & 8.20 & 18.05 & 32.77 \\
\hline
\end{tabular}

\section{Safeguards Assessment}

Under the Fund's safeguards assessment policy, the BB is subject to a safeguards assessment with respect to an augmentation of access under the PRGF Arrangement approved on July 28, 2004. The assessment was completed on January 24, 2005 and concluded that safeguards in place at the $\mathrm{BB}$ require further improvement. Weaknesses were identified in 
the legal, financial reporting, internal audit and internal control areas, and the safeguards assessment recommended measures to address them.

In response to the recommendations arising from the assessment, the Internal Audit Department has (i) established monitoring procedures and submitted to the Audit Committee quarterly monitoring reports on the status of implementation; (ii) established a work program that prioritizes audit coverage and scope based on a risk analysis of operations:

(iii) reconciled data up to June 2006 between audited accounting records and monetary program data; and (iv) engaged an affiliate of an internationally recognized audit firm and intends to engage an internationally recognized audit firm in the future.

\section{Exchange Arrangement}

Exchange regime. Effective May 31, 2003, BB no longer announced a trading band for its foreign exchange transactions. Since then, the exchange regime is characterized as a managed float with no preannounced path for the exchange rate.

At the June 2003 Article IV consultation, the Executive Board approved maintenance by Bangladesh of margin requirement for the opening of letters of credit for the import of goods until November 30, 2003, and also approved the maintenance of restrictions of advance payments for imports and the convertibility and transferability of proceeds of current international transactions in nonresident taka accounts until the conclusion of the second review under the PRGF arrangement or June 30, 2004, whichever is sooner. The restriction pertaining to advance payments for imports was fully lifted as of end-December 2004. At the last Article IV consultation (June 2005), the Executive Board did not approve the maintenance of the restriction on the convertibility and transferability of proceeds from nonresident taka accounts, but noted the authorities' intent to remove this restriction by end-June 2006. The authorities have since advised their intent to remove this restriction during the course of FY07 subject to a favorable balance of payments position.

\section{Article IV Consultation}

The next Article IV consultation will be held subject to the provisions of the decision on consultation cycles approved on July 15, 2002. The last Article IV consultation was concluded on June 7, 2005 (IMF Country Report No. 05/241).

\section{Technical Assistance During 2005-06}

\section{5}

February-March: STA mission conducted the data ROSC. 
March-August: A peripatetic advisor assisted BB with improving accounting standards in accordance with IAS.

May: $\quad$ An MFD expert provided periodic assistance in the area of foreign exchange operations.

February-September: An MFD expert provided assistance in the area of bank restructuring.

March-August: A peripatetic MFD advisor provided assistance in improving BB riskbased internal auditing standards.

March-October: An MFD expert provided assistance in the area of bond market development.

November: $\quad$ An MFD expert provided assistance in the area of bank restructuring.

\section{6}

January-February: An MFD/LEG mission provided assistance in setting up a Financial Intelligence Unit and a regulatory framework for remittances.

February-March: An MFD expert provided assistance in the area of bank restructuring.

February-March: An FDA mission assessed the status of ongoing fiscal reforms.

February-March: An MFD expert provided assistance in the area of bond market development.

April-May: $\quad$ An MFD expert provided in the area of bank restructuring.

July: $\quad$ An LEG mission to assist in setting up a Financial Intelligence Unit.

August: $\quad$ An MFD expert provided assistance in the area of bond market development.

August: $\quad$ An MFD expert provided assistance in the area of central bank internal audit.

\section{Resident Representative}

The resident representative office was established in 1972. The current Resident Representative, Mr. Jonathan Dunn, took up the post in August 2004. 


\section{ANNEX III. BANGLADESH: RELATIONS WITH THE WORLD BANK GROUP ${ }^{5}$}

The World Bank has an expanding assistance program in Bangladesh including investment and policy-based lending, analytical and advisory services, and lending and nonlending technical assistance. The Bank also maintains a policy dialogue on a broad range of macroeconomic and sector issues. This Annex, however, focuses on Bank activities that are complementary to those of the IMF.

\section{World Bank-Bangladesh relations and policy dialogue}

The Poverty Reduction Strategy Paper (PRSP) and the IMF and World Bank Joint Staff Advisory Note (JSAN) were discussed by the World Bank's Board on January 26, 2006. The PRSP was completed in October 2005 after a long and broad-based participatory process, building on the interim PRSP prepared in 2003.

As part of its nonlending services, the Bank has completed key reports. Major reports such as the Public Expenditure Review and the Poverty Assessment - prepared jointly with the AsDB - provided inputs for the country's poverty reduction strategy outlined in the PRSP. A new Poverty Assessment and an Institutional and Public Expenditure Review are being prepared this fiscal year. More recently, the Bank completed a review of trade policies in South Asia, as well as several country-specific reports, including, inter alia: Observance of Standards and Codes (ROSC), Promoting the Rural Non-Farm Sector in Bangladesh, Attaining the Millennium Development Goals in Bangladesh, Economics and Governance of NGOs in Bangladesh, Assessment of Social Safety Nets, End of MFA Quotas: Key Issues and Strategic Options for Bangladesh Ready-Made Garment Industry, and Bangladesh PRSP Forum Update.

Several key reports are underway in FY07, such as, inter alia: a second Investment Climate Assessment, a Strategy for Growth and Employment, which will help assess the longer-term growth challenges facing Bangladesh, and the Dhaka Urban Poverty Study.

Restructuring SOEs. The Bank has engaged in an extensive dialogue with the authorities on SOE-related issues. A report entitled Bangladesh: Review of Public Enterprise Performance and Strategy was discussed widely. In response to a request from the authorities, the Bank provided technical assistance to the Privatization Commission and assisted it in the preparation of the government's new Privatization Policy, which has since been endorsed by Cabinet. Dialogue relating to SOEs in the energy sector has been particularly intensive and the Bank has provided detailed recommendations to the authorities in areas relating to

\footnotetext{
${ }^{5}$ Prepared by World Bank staff.
} 
pricing policy and the regulatory regime for energy and other utilities. As part of a wide reform program of rolling back state ownership and control within the economy, the Enterprise Growth and Bank Modernization Project, approved in June 2004, is supporting restructuring of financial and nonfinancial SOEs.

Restructuring the financial system. The Bank has been actively engaging the authorities in a dialogue on financial sector reform. Together with the Fund, the Bank co-managed the Financial Sector Assessment Program report that was prepared in October 2002. With IDA financing, the government is implementing a program to strengthen the BB. The mentioned Enterprise Growth and Bank Modernization Project is supporting restructuring and eventual divestment of the nationalized commercial banks.

Trade liberalization. In response to requests from the authorities, the Bank has provided regular analytical support to the government. The Bank-supported Export Diversification Project included a component designed to build capacity within the Tariff Commission for tariff analysis and WTO-related negotiations. In addition, the Bank has regularly provided trade-related policy notes as inputs into the annual budget preparation process. A report was also completed last year on trade policy regimes in South Asia and another trade study relating to Bangladesh and India is ongoing. The recently-completed Bangladesh Growth and Export Competitiveness Study examined key macro- and microeconomic factors affecting Bangladesh's competitiveness and provided specific recommendations on priority policy and institutional actions. Further, the Bank has completed a study on the RMG sector, End of MFA quotas: Strategic Options for the Bangladesh Ready-Made Garment Industry. The study identifies several trade-related policy impediments.

Infrastructure development. Infrastructure development is needed in the country for economic growth in general, and private sector development in particular. In this context, the Bank is helping to prepare a power sector strategy, and is supporting Power Sector Development technical assistance, which includes a project preparation facility.

Strengthening governance. The Bank has engaged the government in an active dialogue aimed at improving the investment climate by strengthening accountability and transparency. The new Country Assistance Strategy (CAS) has governance as its core, building several analytical reports on the subject. These include an Institutional and Governance Review, a Country Financial Accountability Assessment, a Country Procurement Assessment, and user surveys on the quality of service delivery. In addition, the Bank is providing technical assistance to the government for improving its procurement systems.

The Bank is currently preparing a series of policy notes on selected aspects of public administration and governance, including policy advice to the Ministry of Finance, National Pay Commission, and the Ministry of Establishment in relation to civil service reform issues, including compensation policy. 
As part of the Bank's regular public expenditure work, a set of policy notes were completed, and these will provide inputs to the ongoing Institutional and Public Expenditure Review. A programmatic approach is being taken to allow better cooperation with other donors. The unifying theme of the notes is the role of public expenditure on growth and poverty reduction, aiming to provide inputs for the government to use in their budget preparation process. As part of the Economic Management Technical Assistance Program (EMTAP), a TA project for the National Board of Revenue will assist in its capacity building, focusing on organizational restructuring, human resource management, development of ICT capacity, as well as strengthening customs, VAT and income tax administration, training, and statistics.

\section{The World Bank's Country Assistance Strategy}

A new, results-based CAS, prepared jointly with AsDB, DfID, and JBIC, was discussed by the World Bank's Board on March 29, 2006. The CAS, covering the FY06-09 period, is aligned with Bangladesh's PRSP, with governance as the core focus across two main pillars: improving the investment climate and empowering the poor. The CAS aims to address sector governance issues in both pillars, as well as core governance issues. This mainstreaming of governance implies that all Bank Group interventions will be as much about governance as they will be about improving sector performance.

\section{The World Bank's Assistance Program}

The Bank has been assisting Bangladesh since FY1973. As of August 2006, the World Bank Group has approved 202 IDA credits, four IDA grants and one IBRD loan for Bangladesh totaling $\$ 12.1$ billion in original commitments. The active portfolio includes 23 projects, representing $\$ 1.98$ billion in net commitments and $\$ 1.3$ billion in undisbursed funds. During FY2005 and FY2006, new commitments totaled \$600 million and \$461.5 million and disbursements totaled $\$ 695$ million and US $\$ 556$ million, respectively (including budget support). The Bank is currently supporting projects in key sectors, including social and human development, rural development, energy and infrastructure, private sector development, finance, and environment.

In FY2005 the Bank approved three IDA credits for a total of $\$ 600$ million. These credits include two policy-based credits and an investment credit prepared within a SWAp framework. The development policy-based lending includes the second Development Support Credit (\$200 million) and the Programmatic Education Sector Adjustment Credit (\$100 million). DSC II continued to support the main themes of the I-PRSP - attaining macroeconomic stability, improving governance, enhancing human development, and ensuring social protection - and recognized the government's efforts at implementing broad reforms in pursuit of the I-PRSP goals. The investment credit was the Health, Nutrition and Population Sector Program II ( $\$ 300$ million), which contributes to a sector-wide program supported by several development partners. 
In FY2006, the Bank approved four credits for a total of $\$ 461.5$ million. Of this amount, $\$ 300$ million correspond to two policy-based credits: Third Development Support Credit (\$200 million) and Second Programmatic Education Sector Adjustment Credit (\$100 million). In addition, two investment credits were approved: Local Governance Support Project (\$111.5 million) and Investment Promotion Finance Facility (\$50 million).

It is projected that the Bank will commit about US\$600 million in FY07. This amount could include about \$290-340 million in budget support, with the rest supporting projects in urban infrastructure, tax modernization, private sector development, agricultural technology, public procurement, and possibly power.

As of December 2005, the IFC's held portfolio stood at $\$ 132.5$ million. Of this, \$102.9 million were under IFC's own account and \$29.6 million for B-loan participants. Projects span a range of sectors including power, telecommunications, cement, and financial markets. No commitments were undertaken in FY2005. During FY2004, IFC committed $\$ 5$ million to a leasing company; ULC, \$40 million to an oil and gas company, Cairn Energy, to support its expenditure needs in Bangladesh and India; a \$30 million second investment in GrameenPhone; and as a small equity investment of $\$ 1.6$ million in a local commercial bank, BRAC Bank, focusing on SMEs. In addition, in FY2002, with the support of several donors, IFC started a regional SME technical assistance facility covering Bangladesh, Bhutan, Nepal, and north-east India.

\section{World Bank-Fund collaboration}

The Bank and the Fund have been working closely in Bangladesh, particularly in areas related to macroeconomic management, the financial sector, reform of SOEs, tax policy and administration, public expenditure management, and issues relating to financial accountability. Bank staff routinely participates in Article IV missions and provide feedback, as requested, on the macroeconomic framework and other aspects of the Fund's macroeconomic dialogue with the authorities. The Bank has also collaborated with the Fund in several areas related to the Report on Observance of Standards and Codes and safeguards assessment. Finally, Fund and Bank staff collaborated closely in preparing the Joint Staff Advisory Note of the PRSP, and in completing the complementary Development Support Credits and PRGF. 


\section{ANNEX IV. BANgladesh: Relations With the ASIAN DeVElopMENT BANK ${ }^{6}$}

\section{Lending and technical assistance operations}

The Asian Development Bank (AsDB) has assisted Bangladesh since 1973. The cumulative commitment and disbursement to Bangladesh stood at $\$ 8.0$ billion and $\$ 5.6$ billion, respectively on August 31, 2006. The cumulative outstanding loan as of August 31, 2006 was $\$ 4.7$ billion. As of end December 2005, public sector lending was dominated by four sectors: agriculture and natural resources (30 percent), energy (26 percent), transport and communications (18 percent), and education (13 percent). Lending in the other sectors, including finance, health, industry, and multisector operations remains relatively small, although these sectors have been given more prominence in recent years. In addition, the AsDB has supported seven private sector projects, valued at \$242 million, including the first build-own-operate power project, and a project to expand access to mobile telecommunications in rural areas.

A total assistance package of $\$ 485$ million approved in 2005 included $\$ 475$ million in loans and \$10 million in grants: Second Urban Primary Health Care (\$40 million), Agribusiness Development (\$43 million), Southwest Area Integrated Water Resources Planning and Management (\$20 million), Emergency Flood Damage Rehabilitation (\$152 million), and Gas Transmission and Development (\$230 million). In addition, during 2005, 13 technical assistance grants amounting to $\$ 7.5$ million were provided.

\section{Country Strategy and Program}

AsDB's present Country Strategy and Program (CSP) for Bangladesh for 2006-10 was approved by the AsDB's Board on October 31, 2005. The new results-based CSP is part of a joint strategy prepared with the U.K.'s Department for International Development, Government of Japan, and World Bank. Over its first three years, the CSP proposes loans totaling about $\$ 1.8$ billion for 15 projects. This will be supported by a technical assistance grant program amounting to about $\$ 13.8$ million.

In 2006, AsDB's assistance program for Bangladesh comprises six loan projects including Improvement of Capital Market and Insurance Governance (already approved), Rural Infrastructure Improvement (already approved), Secondary Education Sector Development Program, Secondary Towns Water Supply and Sanitation, Sustainable Power Sector Development Program, and Multitranche Financing Facility for Railway Sector Investment Program - a new lending modality which comprises several subloans linked to progress of

\footnotetext{
${ }^{6}$ Prepared by the AsDB staff.
} 
reform in the rail sector while allowing greater flexibility and lower financing cost for the government. These projects are expected to contribute substantially to the physical and social infrastructure development in the country. In other areas such as agriculture (i.e., agribusiness), water resources management, and the financial sector, AsDB is playing a supportive role to initiatives led by other development partners. Disaster mitigation, regional cooperation, gender and environment continue to be addressed as key crosscutting issues.

The CSP is aligned with the vision and priorities of the Bangladesh's national poverty reduction strategy. The four partners' joint strategy is built on: (i) improving the investment climate for private sector-led growth and employment; (ii) advancing the social development agenda to empower the poor so that all benefit from growth; and (iii) addressing key governance issues to enable growth and social development.

\section{Policy dialogue}

AsDB is playing a significant role in fostering a constructive dialogue to spearhead reforms in energy, transport and education sectors. AsDB policy dialogue on governance is focusing on reducing corruption, improving financial management, procurement and institutional capacity.

\section{Economic and sector work program}

The AsDB's Asian Development Outlook is updated every year and assesses overall economic performance. Beginning in 2001, the AsDB has also prepared quarterly economic updates. A new bi-monthly Economic Indicators Update has been launched. In support of AsDB's Country Strategy and Program exercise, several new thematic assessments and sector studies have been completed. These include: thematic assessments for poverty, growth and poverty reduction, private sector development, governance, environment, and gender; and sector studies for transport, information and communications technology, water resource development, agriculture and rural development, fisheries, regional cooperation, finance, industry and trade sectors, Dhaka-Chittagong economic corridor development, and public sector borrowing capacity study. At the request of the government, a new study has been completed on the economic impact assessment of the proposed TATA investment in Bangladesh. An analysis of the household income and expenditure survey of 2005 to estimate income poverty based on new data has been completed. A new publicationBangladesh: Key Development Challenges - has been prepared and will be published in 2006. 


\title{
ATTACHMENT I
}

Dhaka, Bangladesh

October 5, 2006

\author{
Mr. Rodrigo de Rato \\ Managing Director \\ International Monetary Fund \\ Washington, D.C., U.S.A.
}

Dear Mr. de Rato:

On behalf of the government of Bangladesh, I hereby transmit the Memorandum of Economic and Financial Policies (MEFP) that reviews recent economic developments and progress in implementing the program supported by the PRGF arrangement, and sets out the objectives and policies the government intends to pursue in fiscal year 2007 (ending in June). A caretaker government, which will be appointed by the president for the period of October 2006 to January 2007, is fully empowered to implement these policies according to Article 58 (D) of the Constitution.

The government remains committed to maintaining macroeconomic stability, pursuing structural reforms - particularly in the area of revenue generation, state bank reform, and the energy sector - and improving governance. These policies continue to be guided by the National Strategy for Accelerated Poverty Reduction which was published in October 2005 and rests on the three pillars of growth, human development, and good governance.

All quantitative performance criteria for end-March were met, except for tax collection by the National Board of Revenue, which fell short of the target by about Tk 14 billion, or 0.2 percent of GDP (MEFP, Table 2). The budget for fiscal year 2007 includes a number of base broadening tax measures, which in combination with tax administrative measures, should help augment revenue by 0.4 percentage points of GDP. A structural performance criterion calling for a report on tax exemptions and their revenue costs by end-April was also not observed (MEFP, Table 3) as the draft report submitted at the time was found to be incomplete. However, a revised and comprehensive report was re-submitted at end-August.

In view of the policies set out in the attached memorandum, and despite election-related delays in a number of reform areas, the government requests waivers for the nonobservance of one quantitative performance criterion and one structural performance criterion and completion of the fifth review with rephasing of the remaining disbursements. The 
government also requests that the current PRGF arrangement be extended by six months to June 19, 2007, with the sixth review assessing compliance with end-December 2006 quantitative performance criteria and specified structural performance criteria. The sixth review is expected to be completed by May 31, 2007.

The government of Bangladesh believes that the policies set out in the attached MEFP are adequate to achieve the objectives of the program, but it will take any further measures that may become appropriate for this purpose. The government will consult with the Fund on the adoption of these measures, and in advance of revisions to the policies contained in the MEFP, in accordance with the Fund's policies on such consultation. The government will provide the Fund with such information as the Fund may request in connection with progress in implementing the economic and financial policies, and achieving the objectives of the program.

The government of Bangladesh intends to make this letter and the attached MEFP available to the public, and authorizes their publication on the IMF website, together with the Fund staff report on the fifth review under the PRGF arrangement, once the Executive Board completes the review.

Sincerely yours,

$/ \mathrm{s} /$

M. Saifur Rahman

Minister for Finance and Planning

Ministry of Finance and Ministry of Planning

Attachments 


\section{BANGLADESH}

\section{Memorandum of Economic and Financial Policies for 2006/07}

\section{October 5, 2006}

\section{INTRODUCTION}

1. The government continues to move forward with the implementation of its reform strategy adopted in June 2003 to move Bangladesh to a higher growth path and faster poverty reduction. This strategy is further articulated in our National Strategy for Accelerated Poverty Reduction (NSAPR). The NSAPR was approved by the National Economic Council and published in October 2005, and was discussed with development partners during the PRS Implementation Forum held in Dhaka during November 15-17, 2005. This memorandum assesses recent economic performance, and lays out the objectives and policies that the government intends to pursue in FY07, supplementing our Memorandum of Economic and Financial Policies (MEFP) dated January 9, 2006.

\section{ReCENT PeRformance}

2. Bangladesh's economy continues to grow. After reaching 6 percent in FY05, despite the impact of higher oil prices and devastating floods, preliminary indicators suggest that real GDP growth picked up to about $61 / 2$ percent in FY06 on the back of a rebound in agricultural production and strong garment exports. Inflation increased to over 7 percent (year-on-year) by June 2005 , on account of higher prices for food imports, and still remains at $63 / 4$ percent as of July 2006. Macroeconomic stability has contributed to sustained growth and, according to the latest estimates, from 2000 to 2005 poverty was reduced by a further 9 percentage points from 49 percent of the population to 40 percent.

3. Macroeconomic management was broadly on course for most of FY06. All quantitative performance criteria for end-March were met except for tax collections by the National Board of Revenue (NBR), which fell short of the target by about Tk 14 billion ( 0.2 percent of GDP), on account of shortfalls in customs duties and VAT on imports. Income tax collections and domestic VAT were on target. Total expenditure remained at prudent levels and was about 1 percent of GDP below projections, largely reflecting lowerthan-budgeted development spending. As a result, the overall deficit for FY06 reached only 3.3 percent of GDP (compared with a budget target of $4 \frac{1}{2}$ percent of GDP) with domestic financing at Tk 86 billion ( 2.1 percent of GDP), only slightly above the indicative target for June 2006. 
4. Bangladesh Bank $(\mathrm{BB})$ has continued to gradually tighten monetary policy during FY06. Since February 2005, interest rates on treasury securities have increased by about 2-3 percentage points, and lending and deposit rates have increased by about 2 percentage points. This has helped reduce private sector credit growth from 25 percent in February 2005 to 18 percent in June 2006, and taken some pressure off the foreign exchange market. To further reduce liquidity in the banking system, the cash reserve requirement was increased from $4 \frac{1}{2}$ percent to 5 percent and the Statutory Liquidity Requirement was raised from 16 to 18 percent in November 2005. BB has also actively used the repo and reverse-repo facilities to enhance daily monetary operations and the end-March performance criterion for NDA of BB was met. However, in spite of BB's efforts to gradually tighten monetary policy, annual broad money growth remained at 19 percent as of June 2006, and the June indicative target for net domestic assets of the central bank was missed by Tk 15 billion.

5. The current account is estimated to have recorded a surplus of 1 percent of GDP in FY06 after recording a deficit of nearly 1 percent of GDP in FY05. This reflects continued strength in exports of garments and in worker remittances, and a slowing in non-oil imports, brought about by a tightening in monetary policy and a depreciation of the taka by about 13 percent since end-June 2005. BB has not sold foreign currency into the interbank market since November 2005 and has purchased about \$23 million in September. The end-March (performance criteria) and end-June (indicative) targets for NIR were comfortably met.

6. Some further progress has been made on the fiscal structural reform agenda, although tax administration efforts have yet to translate into substantial revenue gains. A circular was issued on January 4, 2006 to establish an audit unit that operates independently of the tax and customs departments and reports directly to the National Board of Revenue (NBR)

Chairman. The government has taken important steps to strengthen tax administration further, including by hiring an audit advisor, as well as advisors in the areas of human resources, change management, and computerization and beginning to introduce a uniform taxpayer identification number (structural benchmark for the fifth review). In August 2006, the government completed a study of tax exemptions that is expected to contribute to the formulation of new policy measures to broaden the tax base and help improve revenue collections (completion of the study by end-April was a structural performance criterion for the fifth review). Sustained efforts are being made to identify tax evaders through information gathered by the Central Intelligence Cell (CIC), and by implementing standard and transparent procedures, including notifying delinquent taxpayers and imposing penalties for late payment. Additional staffing and other resources have also been provided to the VAT LTU, and final approval of the VAT LTU organogram by the Office of the Prime Minister was completed in mid-August.

7. With respect to reform of the Nationalized Commercial Banks (NCBs), the divestment of Rupali Bank is now proceeding after some delay due to an earlier court 
injunction. Announcement of a successful bidder was previously planned for end-June as a structural benchmark under the PRGF-supported program but was delayed to allow additional time for road shows and due diligence by interested parties. Following comprehensive technical and fit and proper evaluations, a successful bidder for the bank was announced on August 28 and completion of the sales and purchase agreement is expected in October. The restructuring of the other three NCBs is also progressing as described in paragraph 24 .

8. The financial performance of state-owned enterprises (SOEs) deteriorated in FY06 with aggregate losses of about 1 percent of GDP, compared with $3 / 4$ percent of GDP in FY05. These losses were once again led by the energy sector. The weak performance of the SOEs is largely due to losses by the Bangladesh Petroleum Corporation (BPC), the Power Development Board (PDB), and the airline company (BIMAN). The BPC incurred significant losses in the last two years as domestic prices are only about 65-75 percent of what is needed to meet international levels. In April 2006, we completed a report quantifying the quasi-fiscal costs arising from prices below international levels in the energy and power sector (structural performance criteria for the fifth review), including the implicit subsidies and revenue foregone by the underpricing of natural gas. The report also discusses possible measures to mitigate the impact of energy price adjustments on vulnerable groups and will provide guidance on future policy adjustments.

\section{MACroeconomic Framework ANd Policies For FY07}

9. We remain committed to the reform strategy of private sector-led growth and poverty reduction, as outlined in our NSAPR. Bangladesh's economy remains resilient and growth is expected to remain at 6-7 percent in FY07-09 as structural reforms create a more robust business climate. We are cognizant of the risks that may jeopardize growth and macroeconomic stability and are taking steps to insulate the economy from external shocks. While the impact of the phaseout of the MFA has been more limited than anticipated and exports of ready-made garments (RMG) have risen at a faster pace than originally envisioned, we are taking steps to improve the competitiveness of the RMG sector to ensure its long-term viability. These include reducing trade barriers on RMG inputs and upgrading infrastructure, particularly for improvements in port operations.

\section{A. Fiscal Policy}

10. Our fiscal strategy continues to be driven by the need to protect fiscal sustainability while ensuring adequate support for human capital, physical infrastructure, and anti-poverty programs. To this end, we are making efforts to expand the tax base and improve revenue administration. We remain fully committed to pursuing a revenue increase of about $1 / 2$ percent of GDP in FY07 with the overall deficit limited to 33/4 percent of GDP. Domestic financing will continue to be capped at $2 \frac{1}{2}$ percent of GDP and external support will remain 
primarily on concessional terms. With prudent debt management, and steps to eliminate the creation of contingent liabilities in the SOE sector, the ratios of public debt to GDP and the net present value of debt to revenue should remain within comfortable levels over the medium term.

11. The government will continue to take steps to improve revenue administration, especially by further strengthening the LTUs. Measures will include continuing to improve coordination between the VAT and income tax LTUs, including by (i) conducting joint audits for at least one-third of the eligible audits conducted during June 2006-February 2007 and implementing unified selection criteria; (ii) incorporating businesses registered outside Dhaka into the coverage of the income tax LTU so that both units have national coverage; and (iii) assigning a uniform TIN for LTU taxpayers by end-March (item (iii) to be assessed as a structural performance criterion for the sixth review).

12. A number of other initiatives will also be pursued in the period ahead related to revenue administration. We will continue to focus on the modernization of the NBR along functional lines. With assistance from the World Bank, a strategic reform plan has been developed that is supported by time-bound actions to be implemented over the next three years. The plan includes the introduction of a rigorous self-assessment system, a risk-based auditing system supported by third-party information, and the use of modern technology, particularly an integrated computer system for handling assessment, audit case selection, and collection. An improved board structure will be critical to enhancing NBR management. All auditors within the NBR are under the supervision of the head of the newly established audit unit and/or the NBR chairman, and all audit activities are under the purview of this unit. The audit advisor submitted a six-month action plan in May. The first priority of this action plan is the preparation of an audit manual. For customs administration, we are preparing to issue a tender to hire an external auditor of pre-shipment inspection (PSI) companies.

13. With respect to revenue collections, the FY07 budget projects further improvements. The major factors supporting the revenue forecast are the following: (i) a minimum income tax was introduced and depreciation rules adjusted; (ii) telecommunication fees were increased; (iii) the VAT was extended to cover more retail and service sectors; and (iv) other fees and charges were adjusted. Income earned from international peacekeeping operations and central bank profit transfers are also expected to increase significantly. These policy measures will more than offset the adverse revenue impact of further tariff reductions and contribute to improved revenue of about 0.2 percent of GDP. The number of registered taxpayers is expected to be increased in FY07 by 250,000 following an increase of 200,000 in FY06. These and other ongoing efforts to improve tax administration are projected to boost revenue by 0.2 percent of GDP. Other near-term tax policy measures to boost revenue performance include an adjustment of the assessment base for taxes on property transfers, which we have already initiated; consideration of an increase in taxes on cigarettes; and the 
adjustment of natural gas prices and electricity tariffs during FY07 in order to enhance the revenue base and rationalize the use of energy. These measures, together with ongoing enforcement and collection efforts, should be sufficient to support the projected increase in revenue to 11 percent of GDP. To support further strengthening of tax policy in the future, the government has requested a technical assistance mission from the Fund, expected to take place in November-December 2006. To broaden the tax base, the number of sectors eligible for tax holidays has been reduced by 20 in the last two years. Taking into account the recent completion of a study on tax expenditures, tax exemptions and holidays will be further reduced in the FY08 budget.

14. On the expenditure side, we will ensure that growth-enhancing and poverty-reducing spending is given priority, and that public sector wages are contained. The government continues to make efforts to root out wasteful expenditures and better prioritize spending. Expenditure related to poverty reduction increased steadily from $5 \frac{1}{2}$ percent of GDP in FY03 to $73 / 4$ percent of GDP in the FY06 budget and is targeted to increase further to $8 \frac{1}{2}$ percent of GDP in the FY07 budget. We have stepped up our efforts to strengthen expenditure management by improving project selection and execution under the annual development program (ADP). Expenditure tracking systems have been put in place in three key ministries along with new procedures for project implementation. We are also rolling out the mediumterm budget framework (MTBF) to six more line ministries in the FY07 budget to bring the number of ministries covered by the MTBF to 10 . In consultation with relevant development partners, we have initiated an expenditure review to improve public expenditure management and enhance fiscal transparency and accountability. This review is expected to be completed in FY07. Meanwhile, we have streamlined the project approval process; adopted a new procurement law; delegated more financial authority to the line ministries; and required line ministries to strengthen their own project monitoring capacity. Reflecting these efforts, ADP spending is projected to increase to 5 percent of GDP with the largest increases in the education and power sectors. Current expenditure will be capped at 9 percent of GDP.

15. Consistent with the policy of phasing the 2005 Pay Commission recommendations over three years, expenditure on wages and salaries will be limited to Tk 117 billion (a 17 percent increase over FY06). The government will maintain its selective hiring freeze to reduce employment through attrition while eliminating unnecessary and redundant posts. We are continuing work with the World Bank on a plan for civil service reform in the context of the Economic Management Technical Assistance Program (EMTAP) that will include improving recruitment, performance evaluation and merit-based promotion, training and career planning, and development of a senior civil service.

16. The government is committed to make further fuel price adjustments over the next year and to re-instate the automatic price adjustment mechanism adopted in 2003 by the end of FY07. To reduce BPC's dependence on government-directed lending from the state banks, 
fuel prices were adjusted in June, as described below. An initial sum of Tk 6 billion has been included in the FY07 budget that can be used to cover SOE losses resulting from selling fuel below formula prices. Additional funds will be paid from the budget to cover losses until energy prices are adjusted. Offsetting measures on discretionary spending (such as lowpriority projects) would ensure that the overall deficit does not exceed 4 percent of GDP.

17. Reform of the energy sector SOEs is key to improving their financial performance and reducing infrastructure bottlenecks to growth. We have implemented further fuel price adjustments on June 9 by increasing the prices of petrol and octane by 33 percent and 29 percent, respectively, and diesel and kerosene by 10 percent. However, taking into account changes in international oil prices since June 9, petrol and octane prices are around international levels and diesel and kerosene prices are about 65-75 percent of the price needed to be in line with international prices. Further price adjustments will be implemented in FY07. In the meantime, policy has been shifted to provide transfers from the budget (as described in paragraph 16) to eliminate the need for further bank financing of energy SOEs and support the need for price adjustments in the future. To strengthen PDB, there will need to be further adjustments in electricity tariffs (which will also be implemented in the current fiscal year), as well as ongoing efforts to improve bill collections, curb system losses, and reduce illegal connections, all in line with commitments under World Bank and AsDB programs. To compensate the poorest households for further increases in prices, we shall review and strengthen existing social programs to mitigate the impact of energy price adjustments on vulnerable groups by December 2006 (structural benchmark for the sixth review). Measures might include expanding and strengthening two existing social programs - the Food for Work program and the Primary Education Stipend - which are among the better programs regarding targeting benefits to the poorest households-or introducing ration cards for kerosene or direct cash transfers to the poor.

\section{B. Monetary and External Sector Policies}

18 In line with its monetary policy statement of July 2006, BB's monetary policy stance will aim to keep the monetary program on track, ensure stability in the money and foreign exchange markets, and contain inflation. Growth rates of reserve money, broad money, and private credit are still substantially above program targets, but we intend to maintain our policy of gradual tightening to correct for overshooting of the June NDA target and contain inflationary pressures. Accordingly, interest rates on government securities may need to rise further so that they are clearly positive in real terms and facilitate effective open market operations. BB is targeting a reduction of reserve money growth to 14 percent in FY07 and will continue to implement monetary policy in a manner that limits volatility in the money market and clearly signals its monetary policy stance. These efforts will continue to be supported by strengthened communication by BB through the continued publication of semiannual monetary policy statements, the third of which will be published by January 2007. 
19. Important steps have been taken to improve the functioning of the interbank and treasury bill markets, including the establishment of a settlement system for secondary bond trading and introducing detailed "mark-to-market" guidelines for treasury securities. The government and BB have also taken steps to strengthen debt management operations by separating the government's cash management needs from its debt financing operations by introducing an enhanced ways and means facility and will eliminate the ad hoc treasury bill system. Market-based auctions for treasury securities have been introduced from September on a trial basis and will become permanent by end-November (structural benchmark for the sixth review). To coordinate this process, a Cash and Debt Management Committee has been set up comprising high-level officials from $\mathrm{MoF}$ and $\mathrm{BB}$, and technical assistance is being provided by the Fund to strengthen debt management operations. To increase the number of assets available for monetary operations, the government will convert a portion of the existing stock of outstanding ad hoc T-bills into marketable treasury securities. BB will also consider reintroducing its own securities on a temporary basis, if necessary to increase the number of instruments for conducting monetary policy operations.

20. We are fully committed to the flexible exchange rate regime, and will continue to confine interventions to countering disorderly conditions and building reserves to a more comfortable level. We have taken steps to ensure that no bank is given preferential treatment in the foreign exchange market. The government will continue to rely on market-based mechanisms when the system comes under stress. In this regard, changes in market-based exchange rates continue to underpin the economy's ability to adjust to changes in the external environment without jeopardizing the program's NIR targets or prospects for export-led growth. In early 2006, the financing of oil payments by BPC dried up U.S. dollar liquidity in the market and produced a temporary divergence in the cross rates between the taka/US\$ and taka/euro as several traders were reluctant to see a further depreciation of the taka against the dollar. This anomaly in the market was temporary and was not related to any official action by the authorities. In response, BB has taken steps to ensure that the traders understand their role in facilitating orderly adjustment in the foreign exchange market. We do not intend to resort to the use of moral suasion in an attempt to influence the path of the exchange rate. There is only one remaining restriction under the jurisdiction of IMF Article VIII pertaining to the convertibility and transferability of funds from nonresident taka accounts, and we intend to remove this restriction during the course of FY07, subject to a favorable balance of payments position.

21. BB has made considerable progress in recent years in modernizing its regulatory and supervisory regime. In addition to the core risk management guidelines that were introduced last year, guidelines have been developed covering information technology processes, consumer and small business lending, and the grading of unclassified loans. Provisioning standards have also been tightened through the creation of special mention accounts for loans that have become nonperforming after 90 days. A National Steering Committee led by BB 
has been formed to move forward with the implementation of Basel II banking standards and $\mathrm{BB}$ has strengthened its capacity to supervise and regulate banks effectively by performing comprehensive systems audits and taking action against banks that are in violation of regulatory and prudential norms. BB has strengthened their oversight of problem banks and developed an early warning system covering all banks, and from next year, all banks will be required to go for a credit rating. A micro-credit regulatory authority was also established in August 2006. Over the past year, several NCBs have been in violation of their net open position exposure limits while settling large oil import bills of the state-owned BPC. In response, $\mathrm{BB}$ instructed the banks to strengthen their internal forecasting systems to better anticipate shifts in the demand for foreign exchange and their positions have improved considerably. After the corporatization of the NCBs, they will come under the full regulatory purview of BB.

22. Progress has been made in addressing the recommendations under the safeguards assessment. BB's financial statements for FY05 and FY06 were audited by a local accounting firm. Both the audit and the audit opinion were published. The audit was unqualified and disclosures in the financial statements are being continuously expanded. BB's accounting and internal audit departments are being strengthened, supported by technical assistance from the IMF and World Bank. BB's financial statements will continue to be audited in line with International Financial Reporting Standards (IFRS) to help underpin its operational and policymaking credibility. The FY06 audit was conducted by two local affiliates of international accounting firms in the final year of their contract. Beginning in FY07, the government intends to contract an internationally accredited auditor. As part of efforts to improve its internal accounting system, BB will take steps to resolve the issues that have caused delays in implementing the new IT system for its financial operations and accounting functions.

23. In the face of the phaseout of MFA quotas, we are adopting further measures to reduce the anti-export bias of our trade regime and to improve the investment climate. We are also seeking duty-free access for RMG exports to the U.S. market. With respect to overall trade policy, we have eliminated all quantitative restrictions except those based on grounds of health, national security, religion, and environmental protection, and the government has further reduced average import duties (including surcharges) by 2.2 percentage points in the context of the FY07 budget.

\section{Reforming the Nationalized Commercial Banks}

24. After several delays, the divestment of Rupali Bank is nearing completion. At the point of sale, the government will remove from Rupali's books, and assume full responsibility for the liabilities of existing pensioners and for the accrued rights of current employees, with cash payments made from the government's budget as these payments 
become due. The government will also issue bonds to Rupali to cover the capital shortfall (up to zero capital) as well as the underprovisioning in private loans in the statutory accounts at end-2005. All nonperforming SOE loans and other clearly defined liabilities that are the responsibility of the government will be replaced with a single loan from Rupali to the government bearing the prevailing five-year treasury bond rate. The majority shareholder will have management control over all aspects of the bank's operations, including on HR policies and pay scales.

25. The government is stepping up efforts to restructure the other NCBs in order to improve their financial performance. BB continues to closely monitor the NCB's compliance with MOUs agreed with BB. While performance under the MOUs has been mixed, they have effectively served to limit further deterioration in the operations of the banks. Despite being subject to state-mandated extensions of credit, particularly to the BPC for oil financing, limits on credit extension in the NCBs have been observed except for Agrani Bank. Corporatization of the banks will provide their managements and boards with autonomy over operational decisions and preclude their need to seek authority from the Ministry of Finance on operational matters and bring them under the full regulatory authority of $\mathrm{BB}$, and will be completed by end-March (structural performance criterion for the sixth review). BB will ensure that all NCBs take steps to comply fully with its limits on banks net open positions by December (structural benchmark for the sixth review). Appointment letters have been issued to the managing directors of two NCBs with performance targets for which they will be held accountable, and performance indicators for the third state bank will be issued in the near future. At the same time, the consulting teams have been instructed to share information and work closely with the bank management to operationalize the restructuring plans.

\section{Governance}

26. We are taking concerted actions to implement an anti-corruption strategy and strengthen our anti-money laundering efforts. A full organizational chart (organogram) of the Anti-Corruption Commission (ACC), established in November 2004, was approved by the Prime Minister in July 2006. This will enable the ACC to recruit staff and become fully operational. We intend to establish a neutral recruitment committee to screen applicants for positions in the ACC and are developing with AsDB's assistance, a set of operational and prosecutorial rules for the ACC. Additional technical assistance for the government's overall anti-corruption strategy is being provided by the World Bank and USAID, and we are implementing measures to improve financial management and procurement practices of entities in the power, health, education and other sectors. To further improve policy accountability and fiscal transparency, the government intends to implement a Public Financial Management Improvement Plan. In this context, we have listed all explicit government guarantees on external obligations in the FY07 budget documents. Other nearterm priorities include strengthening bank reconciliation functions across the government, 
and improving cash standards of accounting. A tax ombudsman was also established in July 2006 to help ensure transparency and accountability. It is expected that budget documents will include an annex on the fiscal costs and risks from quasi-fiscal activities by SOEs once comprehensive and verifiable data are available. A new Money Laundering Prevention Act has been drafted and BB is steadily strengthening its capacity to prevent terrorist financing and detect suspicious financial transactions, and to sanction banks that do not report them.

\section{E. Program Monitoring}

27. To allow time to complete the reforms under the PRGF, we are requesting extension of the current PRGF arrangement by six months to June 19, 2007.

28. With regard to program monitoring, quantitative performance criteria for endDecember 2006 and indicative targets for March 2007 and June 2007 are being proposed. The sixth review will assess compliance with the end-December 2006 quantitative performance criteria and specified structural conditionality. Key structural benchmarks and structural performance criteria for the sixth review will continue to focus on fiscal, NCB, and energy sector reforms. Technical assistance coordinated closely with the World Bank and DFID will remain essential to building capacity, especially in tax administration, public expenditure management, and NCB reform.

29. The policy commitments in this document cover the period up to mid-2007 when the proposed extension of the arrangement would expire. A caretaker interim government, which will be appointed by the President in October, will be fully empowered to implement these policies that have been agreed by the government of Bangladesh in accordance with the provisions of Article 58 (D) of the Constitution.

Attachments:

MEFP Table 1. Key Economic Indicators, FY03-11

MEFP Table 2. Indicative Targets and Quantitative Performance Criteria under the PRGF Arrangement, June 2005-June 2007

MEFP Table 3. Structural Performance Criteria and Benchmarks under the PRGF Arrangement

MEFP Annex I. Near-Term Reform Action Plan for Nationalized Commercial Banks

MEFP Annex II. Addendum to the Technical Memorandum of Understanding 
MEFP Table 1. Bangladesh: Key Economic Indicators, FY03-11 1/

\begin{tabular}{|c|c|c|c|c|c|c|c|c|c|c|}
\hline \multirow{3}{*}{ National income and prices (percent change) } & \multirow[b]{2}{*}{$2002 / 03$} & \multirow{2}{*}{\multicolumn{2}{|c|}{$2003 / 042004 / 05$}} & \multirow{2}{*}{\multicolumn{2}{|c|}{$\begin{array}{c}\text { Rev. Prog. Prelim. } \\
2005 / 06 \\
\end{array}$}} & \multicolumn{5}{|c|}{ Projection } \\
\hline & & & & & & \multirow[t]{2}{*}{$2006 / 07$} & \multirow[t]{2}{*}{$2007 / 08$} & \multirow[t]{2}{*}{$2008 / 09$} & \multirow[t]{2}{*}{$2009 / 10$} & \multirow[t]{2}{*}{$2010 / 11$} \\
\hline & & & & & & & & & & \\
\hline Real GDP & 5.3 & 6.3 & 6.0 & 6.0 & 6.5 & 6.0 & 6.5 & 6.5 & 6.5 & 6.5 \\
\hline GDP deflator & 4.5 & 4.2 & 4.8 & 6.0 & 5.5 & 6.0 & 5.0 & 5.1 & 4.5 & 3.7 \\
\hline CPI inflation (annual average) 2/ & 4.4 & 5.8 & 6.5 & 7.5 & 7.0 & 7.0 & 5.2 & 5.1 & 4.5 & 3.7 \\
\hline \multicolumn{11}{|l|}{ Central government operations (percent of GDP) } \\
\hline Total revenue & 10.3 & 10.2 & 10.5 & 11.0 & 10.6 & 11.0 & 11.4 & 11.5 & 11.7 & 12.0 \\
\hline Tax & 8.3 & 8.2 & 8.5 & 9.0 & 8.5 & 8.8 & 9.4 & 9.5 & 9.6 & 9.8 \\
\hline Nontax & 2.0 & 1.9 & 2.0 & 2.0 & 2.1 & 2.1 & 2.0 & 2.1 & 2.1 & 2.2 \\
\hline Total expenditure & 13.7 & 13.1 & 13.9 & 15.1 & 13.9 & 14.8 & 14.9 & 15.1 & 15.3 & 15.5 \\
\hline Current expenditure & 8.1 & 7.8 & 8.4 & 8.7 & 8.4 & 9.1 & 8.3 & 8.3 & 8.3 & 8.2 \\
\hline Of which: Interest payments & 1.9 & 1.6 & 1.7 & 1.8 & 1.8 & 1.6 & 1.7 & 1.7 & 1.6 & 1.5 \\
\hline Of which: Subsidies & & 0.4 & 0.6 & 0.4 & 0.4 & 1.3 & 0.4 & 0.4 & 0.4 & 0.4 \\
\hline Annual Development Program & 5.4 & 5.0 & 5.0 & 5.4 & 4.7 & 4.9 & 5.7 & 5.6 & 5.8 & 6.2 \\
\hline Other expenditures $3 /$ & 0.2 & 0.3 & 0.5 & 1.0 & 0.8 & 0.8 & 0.9 & 1.2 & 1.2 & 1.1 \\
\hline Overall balance (excluding grants) & -3.4 & -2.9 & -3.4 & -4.0 & -3.3 & -3.8 & -3.5 & -3.6 & -3.6 & -3.6 \\
\hline Primary balance & -1.5 & -1.2 & -1.7 & -2.3 & -1.5 & -2.2 & -1.8 & -1.8 & -2.0 & -2.0 \\
\hline Financing (net) & 3.4 & 2.9 & 3.4 & 4.0 & 3.3 & 3.8 & 3.5 & 3.6 & 3.6 & 3.6 \\
\hline Domestic 4/ & 1.2 & 1.8 & 1.7 & 2.0 & 2.1 & 2.6 & 1.8 & 1.7 & 1.7 & 1.6 \\
\hline External & 2.1 & 1.1 & 1.6 & 2.0 & 1.2 & 1.2 & 1.7 & 1.9 & 1.9 & 2.0 \\
\hline Total central government debt (percent of GDP) & 51.1 & 48.7 & 47.6 & 48.5 & 46.9 & 45.7 & 44.1 & 42.5 & 41.4 & 40.7 \\
\hline \multicolumn{11}{|l|}{ Money and credit (end of year; percent change) } \\
\hline Net domestic assets & 12.2 & 13.4 & 17.1 & 15.0 & 19.6 & 14.4 & 14.7 & 14.4 & 14.3 & 13.5 \\
\hline Credit to private sector & 12.6 & 12.0 & 17.0 & 13.9 & 18.3 & 14.0 & 14.1 & 13.4 & 13.3 & 12.2 \\
\hline Broad money (M2) & 15.6 & 13.8 & 16.7 & 14.3 & 19.3 & 14.7 & 14.0 & 13.8 & 13.7 & 12.9 \\
\hline \multicolumn{11}{|l|}{ Balance of payments (in billions of U.S. dollars) 5/ } \\
\hline Exports, f.o.b. & 6.5 & 7.5 & 8.6 & 9.6 & 10.4 & 12.0 & 13.2 & 14.5 & 15.9 & 17.5 \\
\hline (Annual percent change) & 9.5 & 15.8 & 14.0 & 11.7 & 23.1 & 15.2 & 10.0 & 9.8 & 9.8 & 9.9 \\
\hline Imports, f.o.b. & 8.7 & 9.8 & 11.9 & 13.7 & 13.3 & 15.4 & 17.6 & 19.4 & 21.1 & 22.9 \\
\hline (Annual percent change) & 13.1 & 13.0 & 20.6 & 15.0 & 12.1 & 16.0 & 14.0 & 10.5 & 8.7 & 8.4 \\
\hline Current account & 0.1 & 0.2 & -0.6 & -1.2 & 0.6 & 0.3 & -0.5 & -0.9 & -1.1 & -1.2 \\
\hline (Percent of GDP) & 0.1 & 0.3 & -0.9 & -1.9 & 0.9 & 0.4 & -0.6 & -1.2 & -1.3 & -1.3 \\
\hline Gross official reserves (in billions of U.S. dollars) & 2.5 & 2.7 & 2.9 & 3.3 & 3.4 & 3.8 & 4.6 & 5.3 & 6.2 & 7.1 \\
\hline In months of imports of goods and nonfactor services & 2.9 & 2.8 & 2.5 & 2.5 & 2.6 & 2.5 & 2.7 & 2.8 & 3.0 & 3.1 \\
\hline \multicolumn{11}{|l|}{ Memorandum item: } \\
\hline Nominal GDP (in billions of taka) & 3,006 & 3,330 & 3,707 & 4,142 & 4,166 & 4,682 & 5,235 & 5,863 & 6,527 & 7,214 \\
\hline
\end{tabular}

Sources: Data provided by the Bangladesh authorities; and IMF staff estimates and projections.

$1 /$ Fiscal year begins July 1 .

2/ CPI has recently been rebased using FY96 weights.

$3 /$ Consists of other capital, net lending, food account balances, check float and discrepancy.

4/ Includes estimated privatization receipts of 0.2 percent of GDP in FY07.

$5 /$ Balance of payments is presented on the basis of BPM5. 


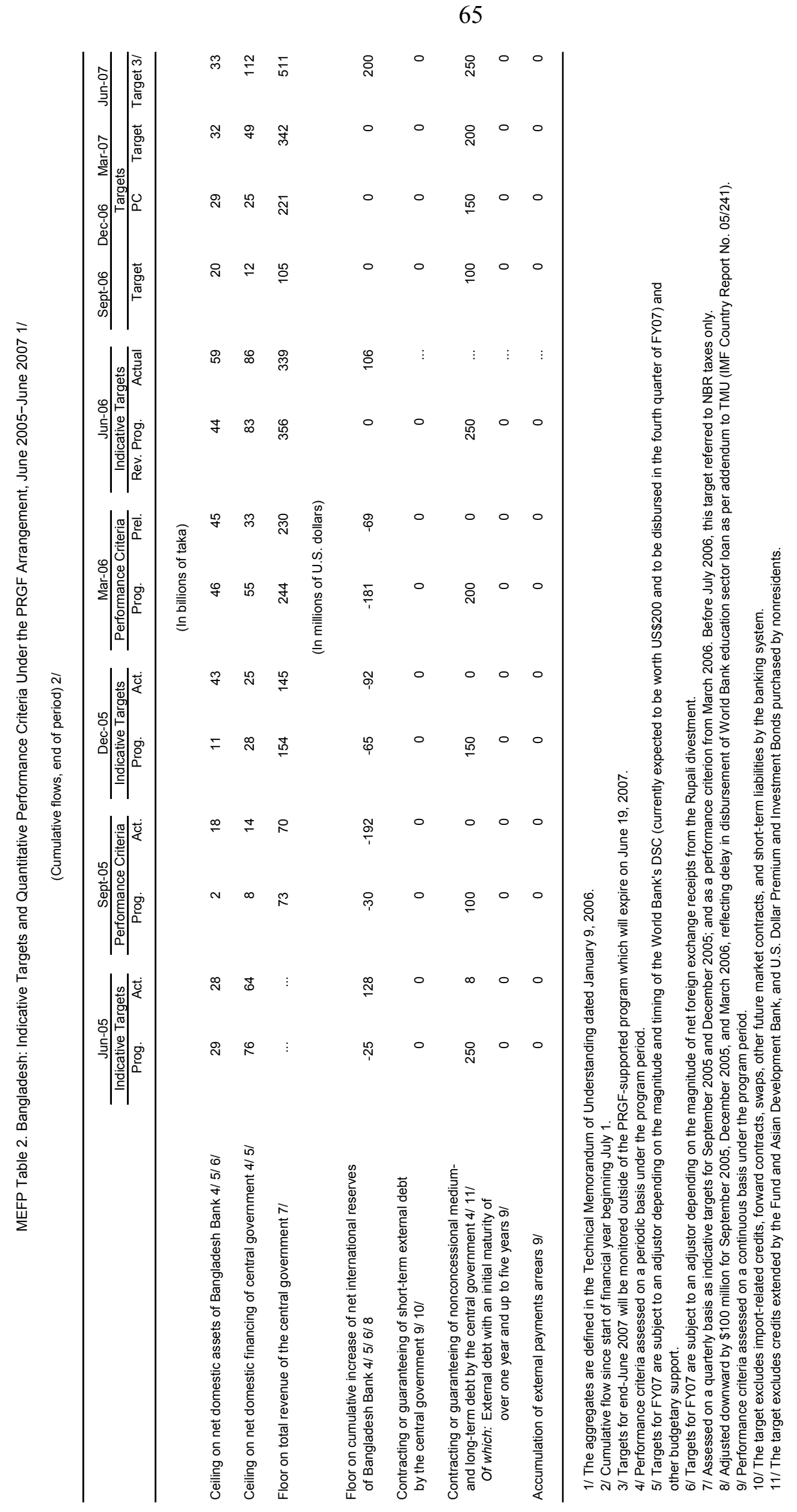




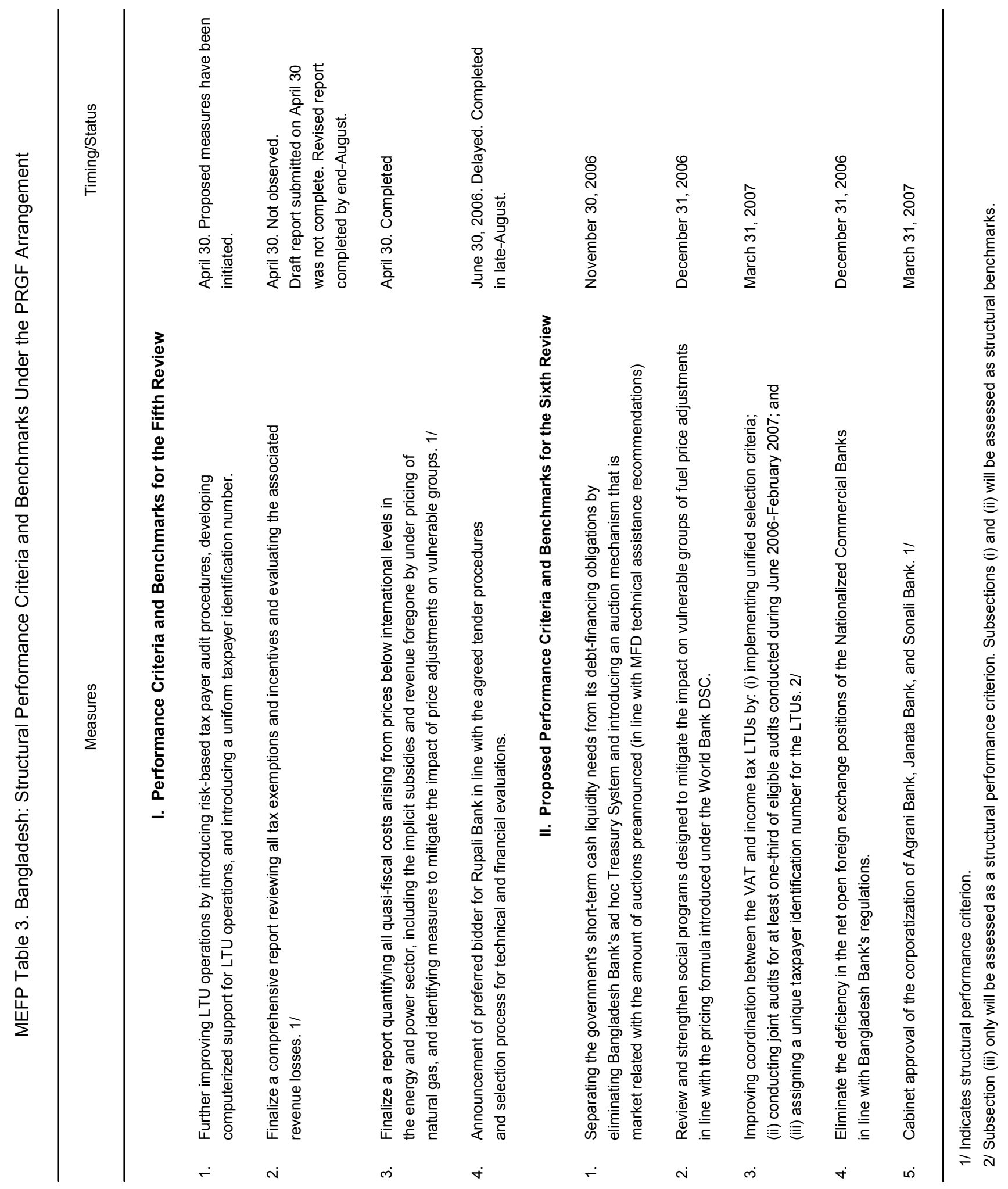




\section{MEFP ANNEX I: NEAR-TERM REFORM ACTION PLAN FOR NATIONALIZED COMMERCIAL BANKS}

1. This Annex updates Annex I to our Memorandum of Economic and Financial Policies dated January 9, 2006. The government remains committed to the restructuring and eventual divestment of the Nationalized Commercial Banks (NCBs) and will take all necessary steps to ensure the timely implementation of the NCB reform program.

2. The government is committed to giving the NCBs sufficient autonomy to operate in a commercially viable manner. We have reiterated this commitment in a letter dated April 13, 2006 to the managing directors of Sonali, Agrani, and Janata banks which stressed that the boards of directors of the banks will be responsible for their superintendence, subject to occasional orders from the government. Bangladesh Bank (BB) and the Working Group on NCB reform is monitoring the implementation of the restructuring program and is providing regular reports to the Ministry of Finance $(\mathrm{MoF})$ on the implementation status of the restructuring measures taken by the banks. All reports prepared by the management consultants are being shared with the respective boards and managements of the banks.

3. To further place the NCBs on a commercial footing, Agrani, Janata, and Sonali will be corporatized by end-March 2007 and brought under the Bank Company's Act (BCA). Corporatization has given the banks additional autonomy and put them firmly under the regulatory purview of $\mathrm{BB}$.

4. The NCBs will be bound by Memoranda of Understanding (MOUs) until they are divested. Performance under the MOUs will be closely monitored by BB and once corporatized, remedial actions will be taken against those banks that are in violation of their MOU commitments.

\section{A. Bank-By-Bank Action Plans}

\section{Rupali Bank}

5. The government has selected a successful bidder for the bank and a sales and purchase agreement is expected to be completed by mid-October. As part of the divestment process, the government has clarified the modalities for fulfilling its various commitments with respect to: (i) the assumption of pension liabilities up to the point of sale;

(ii) introduction of a VRS; (iii) the issuance of a government bond to bring its level of capital to zero and to account for the underprovisioning for private loans in the statutory accounts as of end-2005, and (iv) conversion of SOE loans and other clearly defined government liabilities into a single loan on market terms from Rupali Bank to the government. 
Agrani Bank, Janata Bank, and Sonali Bank

6. The objective is to bring Agrani Bank, Janata Bank, and Sonali Bank to the point of divestment in the near term. To prepare for this objective, the following steps will be taken:

- $\quad$ Revising the contract and terms of reference of the managing directors of Agrani, Janata, and Sonali to incorporate explicit qualitative and quantitative performance criteria against which their performance will be measured. The managing directors will be given full management authority, which will allow them and the bank's board to take decisions on all operational matters without prior approval from the Ministry of Finance.

- $\quad$ Hiring qualified general managers/deputy general managers on a contractual basis in key departments who will be paid competitive salaries and carry out the needed operational restructuring of the banks. 


\section{MEFP ANNEX II. AdDEndum to THE TECHNICAL MEMORANDUM OF UNDERSTANDing}

The Technical Memorandum of Understanding (TMU) dated January 9, 2006 (IMF Country Report No. 06/57) will be modified as follows:

- $\quad$ Para. 1, page 63 will be replaced by:

1. For program purposes, any foreign asset, liability, or cash flow denominated in a currency other than the U.S. dollar shall be converted into U.S. dollars by applying the appropriate end-of-period exchange rate for March 31, 2006, as published in the Fund's International Financial Statistics (Table 1).

Table 1. Selected End-of-Period Exchange Rates

\begin{tabular}{|l|l|l|l|}
\hline Taka per U.S. dollar & 71.5458 & Indian rupee per U.S. dollar & 44.6850 \\
\hline SDR per U.S. dollar & 1.4409 & Pakistani rupee per U.S. dollar & 59.9771 \\
\hline Australian dollar per U.S. dollar & 1.3968 & Swedish korma per U.S. dollar & 7.7921 \\
\hline British pound per U.S. dollar & 0.5764 & Japanese yen per U.S. dollar & 117.4000 \\
\hline Canadian dollar per U.S. dollar & 1.1671 & $\begin{array}{l}\text { Gold price in U.S. dollars per troy } \\
\text { ounce (London PM fixed) }\end{array}$ & 557.0930 \\
\hline Euro per U.S. dollar & 0.8262 & & \\
\hline
\end{tabular}

Source: Fund's International Financial Statistics.

- $\quad$ The following additional paragraphs will be added at the end of page 64 :

2. The program for FY07 envisions the receipt of US\$200 million in budget support in the fourth quarter of the year. Program targets for end-December 2006, end-March 2007, and end-June 2007 pertaining to Bangladesh Bank's (BB) NIR floor will be adjusted upward (downward), and program targets pertaining to BB's NDA ceiling and the ceiling on the central government's net domestic financing will be adjusted downward (upward) for any excess (shortfall) in program disbursements from the World Bank or AsDB. In addition, the program target pertaining to BB's NIR floor will be adjusted upward and BB's NDA ceiling adjusted downward for net foreign exchange receipts from the Rupali Bank divestment.

3. The performance targets on the revenue floor will pertain to total revenue collections by the central government (NBR tax revenue plus non-NBR tax revenue plus non-tax revenue). 



\section{Statement by the IMF Staff Representative October 27, 2006}

1. This statement contains information that has become available since the staff report was circulated to the Board on October 10, 2006. This information does not alter the thrust of the staff appraisal.

2. Despite emerging power shortages and recurring work stoppages in the run-up to the election, the growth momentum remains strong and inflation continues to ease. Manufacturing growth reached 11/1/2 percent in the last quarter of FY06, up from 8 percent in FY05. Exports rose by 31 percent in the first two months of FY07 over the same period last year, led by woven garments, knitwear, and leather products. Strong domestic demand is set to underpin the growth momentum. Outstanding letters of credit for imports were up by 14 percent (year-on-year) in August and inward remittances continue to grow at close to 25 percent. Inflation remains on a downward trend, aided by a strong taka, and reached $62 / 3$ percent (year-on-year) in August.

3. On October 5, the Bangladesh Bureau of Statistics issued the Household Income and Expenditure Survey (HIES) 2005. The survey confirms preliminary data in the staff report which shows that poverty has declined considerably. Between 2000 and 2005, the share of the population below the poverty line declined by 9 percentage points to 40 percent. In urban areas the poverty rate declined to 28 percent, whereas in rural areas the poverty rate declined to $43 \frac{3}{4}$ percent. The number of people that have been lifted out of poverty is robust to alternative definitions of the poverty line. The HIES also finds that consumption inequality has dropped slightly at the national level during 2000-05 driven by an improvement in urban areas.

4. Full information on fiscal performance in the first quarter of FY07 is not yet available. Staff estimates that the end-September indicative target for revenue collection is likely to have been observed. Tax revenue through end-September is slightly below target, partly due to the fact that the collection of the new minimum income tax will not begin until November. However, data through August suggest that nontax revenue is likely to compensate for this. Despite revenue developments broadly in line with projections, net domestic financing of the government has been higher than expected, reportedly reflecting advanced implementation of some expenditure items as well as a small shortfall in external financing. As a result, staff projects that the end-September indicative target on domestic financing may have been breached. These developments underscore the importance of enhancing revenue collections and containing overall expenditure, especially during the pre-election period, while continuing to improve the execution of spending in priority areas as emphasized in the staff appraisal. 
5. Monetary aggregates are gradually returning to program levels. The central bank continues to tighten monetary policy as evidenced by reverse repo activity and rising treasury bill rates, up 15 basis points this fiscal year. To further mop up liquidity during the transition to a fully developed market for treasury securities, the central bank has reintroduced Bangladesh Bank bills in October. All indicative monetary targets for endSeptember were met and broad money and private credit growth declined to 20 and 18 percent, respectively. Strong export and remittance receipts have exerted upward pressure on the Taka, which appreciated by $3 \frac{1}{2}$ percent against the U.S. dollar since end-August and has helped sustain gross official reserves equivalent to 2.6 months of imports. On October 12, Bangladesh Bank provided a guarantee to Standard Chartered Bank for a one-year trade credit of $\$ 250$ million to the Bangladesh Petroleum Company for oil financing. The loan is import related and on similar terms as an existing facility with the Islamic Development Bank, and excluded from the program ceiling on short-term debt.

6. On October 5, the Prime Minister approved the divestment of Rupali Bank. A sales and purchase agreement is presently being finalized and will be sent to the Ministry of Law for final clearance. The payment and transfer of ownership is expected to take place in the coming weeks. 


\section{IMF Executive Board Completes Fifth Review under Bangladesh's PRGF Arrangement and Approves US\$49.7 Million Disbursement}

The Executive Board of the International Monetary Fund (IMF) today completed the fifth review of Bangladesh's economic performance under the Poverty Reduction and Growth Facility (PRGF) arrangement. The completion of this review makes available to Bangladesh an amount equivalent to SDR 33.67 million (about US\$49.7 million), bringing total disbursements to SDR 316.73 million (about US\$467.4 million).

The Board also decided today to extend the current PRGF arrangement to June 19, 2007, to allow the remaining sixth review under the arrangement to be completed. In addition the Board agreed to waive the nonobservance of a quantitative performance criterion and a structural performance criterion.

The IMF's Executive Board approved Bangladesh's three-year PRGF arrangement on June 20, 2003 (see Press Release No. 03/92) for an amount equivalent to SDR 347 million (about US\$512 million). The Board also approved on July 28, 2004, Bangladesh's request for activation of the newly created Trade Integration Mechanism with an augmentation of the PRGF arrangement amounting to SDR 53.33 million (about US\$78.7 million- see Press Release No. 04/161). As a result, the total amount under the PRGF arrangement increased to SDR 400.33 million (about US\$590.7 million).

Following today's Executive Board discussion, Mr. Takatoshi Kato, IMF Deputy Managing Director and Acting Chair, made the following statement:

"Bangladesh's economy continues to perform strongly under the PRGF-supported program. Sustained growth with moderate inflation has contributed to a significant reduction in poverty over the last five years, and considerable progress has been achieved toward meeting the Millennium Development Goals. Nevertheless, Bangladesh still faces formidable challenges in addressing infrastructure constraints and improving social services, and the authorities will need to maintain sound policies, speed up the pace of key structural reforms in the banking and energy sectors, and reinforce their revenue mobilization efforts. 
"The improved functioning of the foreign exchange market, including flexible exchange rate adjustments in response to market forces, has helped absorb the shock of higher oil prices and the phase-out of MFA quotas on garments. It has also supported the robust growth of exports and remittance receipts and the gradual increase in international reserves.

"While the overall fiscal position has remained prudent, revenue collection relative to GDP remains one of the lowest in the world. The initial results of revenue reforms are encouraging, but continued revenue mobilization efforts will remain vital to finance Bangladesh's need for infrastructure and enhanced social services while maintaining debt at sustainable levels. This will involve strengthened compliance and enforcement, reduced tax exemptions and incentives, and a broadening of the tax base. Efforts will also be made to improve the implementation capacity of the annual development program and the effectiveness of pro-poor spending.

“Bangladesh Bank's stated policy of gradual monetary tightening while inflationary pressures persist is appropriate. A more active use of open market operations and higher interest rates on treasury and central bank securities will help contain inflation in light of continued strong domestic demand and private credit growth.

"Stepped up reform efforts are needed in the Nationalized Commercial Banks (NCBs) to further enhance financial intermediation and to reduce contingent liabilities. The imminent divestment of Rupali Bank is a positive milestone and should be followed by steps to corporatize the remaining three state banks and hold their managements accountable against performance indicators.

"Fuel price adjustments and recent declines in international prices have helped contain losses in the energy sector. However, it will be important to move towards a full pass-through of international oil prices, combined with targeted safety net programs to mitigate the impact on vulnerable groups. This will also provide room for priority spending on social services and infrastructure." Mr. Kato said.

The PRGF is the IMF's concessional facility for low-income countries. PRGF-supported programs are based on country-owned poverty reduction strategies adopted in a participatory process involving civil society and development partners and articulated in the Poverty Reduction Strategy Paper (PRSP). This is intended to ensure that PRGF-supported programs are consistent with a comprehensive framework for macroeconomic, structural, and social policies to foster growth and reduce poverty. PRGF loans carry an annual interest rate of 0.5 percent and are repayable over 10 years with a 51/2-year grace period on principal payments. 


\section{Statement by B. P. Misra, Executive Director for Bangladesh and Rnajit Bannerji, Senior Advisor to Executive Director October 27, 2006}

1. The Staff Report presents a fair summary of the status of the Bangladesh PRGF. To that extent, we would not like to be repetitive in this buff statement. We will only seek to elaborate the gains that Bangladesh has made in the current PRGF program. We will also seek to explain causes behind some of the shortfalls in performance. Lastly, we will underscore the need to carry the current PRGF program forward.

2.0 From a pure program perspective, Bangladesh can be singled out as one of the Fund's few - and far between - success stories under the Poverty Reduction and Growth Facility Program. Indeed, the basic premise of the PRGF requires reiteration, lest we tend to miss the wood for the trees. Firstly, such programs should promote pro-poor growth. The achievement of this broad outcome is enabled by the country following prudent macro-economic policies both affecting the external and domestic sectors. The resultant fiscal space in an environment of benign inflationary expectations enables increased public investment in infrastructure, primary education and public health, and fosters an environment that encourages private sector investments. By any yardstick, Bangladesh's achievements thus far, have been impressive.

2.1 Growth Performance: As the staff paper points out, growth has been at a steady 6 percent per annum over the past four years. Indeed, it is expected to be at 6.5 percent in FY07. This has been despite the oil price shock, and crippling floods in FY 04/05.

2.2 Poverty Alleviation: The latest poverty headcount survey shows that the population subsisting below the poverty line fell by 9 percentage points from 2001 to 2005, coinciding broadly with the PRGF program period. This, by any measure, is an impressive performance. Bangladesh looks well on course to meeting the first millennium development goal of halving poverty by 2015 .

2.3 Fiscal Sustainability: Over the program period, the Government has consistently met its overall deficit targets. Domestic financing of the deficit has been limited to 2 percent of GDP, and central government debt has stabilized at 47 percent of GDP.

2.4 Health and Education: Primary enrollment rates for both male and female children are close to 100 percent. Literacy levels have gone up sharply and all relevant health indicators show Bangladesh achieving the MDGs by 2015. Surely, such impressive improvements would scarcely be possible without increased outlays in these sectors, as well as improved quality of government spending. 
2.5 Business Environment: The World Investment Report 2006 brought out by UNCTAD recorded Bangladesh as registering a 50 percent growth in FDI in 2005, the second highest in South Asia. FDI in 2006, was estimated at US\$692 million as against $\$ 460$ million in 2004 and $\$ 350$ million in 2003. These again, are impressive rates of growth, and would certainly not obtain if market perceptions were not optimistic. In fact, if the IMF's definition of FDI is employed (recognizing reinvestment of profits as FDI), the 2005 FDI figures stood at US $\$ 845$ million, an increase of 84 percent over FY 2004. This indeed, is the highest increase amongst countries in percentage terms, over the reporting period.

3. The staff papers also highlight the reform of the foreign exchange regime, trade reform and the monetary stance. The resultant outcomes, buttress our observations in paragraph 2.

4. Turning to the two major shortfalls in the current year, we wish to comment firstly, on the stagnant tax: GDP ratio in FY 06 over the previous year. We would submit that initial program objective of a 0.5 percent increase per year in the tax: GDP ratio was

over-ambitious. Tax buoyancies increase gradually over time. This can be borne out by any number of cross-country studies. When such improvements are expected to be kicked-in by better tax-compliance rather than changes in the tax rates, we must be mindful of the fact that administrative changes, reforms, rationalization measures that contribute to better tax compliance take time. These are not steps that can be taken instantaneously, and certainly the effects of these changes bear results after lags. Thus, the reforms in personal income taxes and VAT implemented in the earlier years of the current program have now started showing results. The authorities have completed the study on tax exemptions. Putting these recommendations into place, will ultimately have positive results on indirect taxes, but with a lag. We would, therefore, submit that too much should not be read into a stagnant tax: GDP ratio, for one year alone.

5. There has been a significant pass through in higher energy prices already. Moreover, a large percentage of the implicit subsidy has been budgeted for. Looking forward, we believe that the recent stabilization in oil prices, will make it relatively easier for the authorities to fully adjust the earlier oil prices increase more fully in the months ahead.

6. The divestment of Rupali Bank is also complete, and if future operations are successful, it will enthuse the authorities to move forward on other public sector commercial banks.

7. For the reasons that we have elaborated in this buff, we would urge the Board to accede to Bangladesh's request for the waiver of a performance criterion, extension of the arrangement and its rephasing. 